UNIVERSIDADE DE SÃO PAULO

FACULDADE DE FILOSOFIA, LETRAS E CIÊNCIAS HUMANAS

DEPARTAMENTO DE LETRAS ORIENTAIS

PROGRAMA DE LITERATURA E CULTURA RUSSA

GIULIANA TEIXEIRA DE ALMEIDA

\title{
Pelo Prisma Biográfico: Joseph Frank e
}

\section{Dostoiévski}




\author{
UNIVERSIDADE DE SÃO PAULO \\ FACULDADE DE FILOSOFIA, LETRAS E CIÊNCIAS HUMANAS \\ DEPARTAMENTO DE LETRAS ORIENTAIS \\ PROGRAMA DE LITERATURA E CULTURA RUSSA
}

\title{
Pelo Prisma Biográfico: Joseph Frank e
}

\section{Dostoiévski}

Giuliana Teixeira de Almeida

Dissertação apresentada ao Programa de Pósgraduação em Literatura e Cultura Russa do Departamento de Letras Orientais da Faculdade de Filosofia, Letras e Ciências Humanas da Universidade de São Paulo como requisito para obtenção do título de Mestra em Literatura e Cultura Russa. Pesquisa desenvolvida com apoio da Fundação de Amparo à Pesquisa do Estado de São Paulo (FAPESP).

Orientador: Prof. Dr. Bruno Barretto Gomide 
Autorizo a reprodução e divulgação total ou parcial deste trabalho, por qualquer meio convencional ou eletrônico, para fins de estudo e pesquisa, desde que citada a fonte.

Catalogação na Publicação

Serviço de Biblioteca e Documentação

Faculdade de Filosofia, Letras e Ciências Humanas da Universidade de São Paulo

Almeida, Giuliana Teixeira de

Pelo Prisma Biográfico: Joseph Frank e Dostoiévski / Giuliana Teixeira de Almeida; orientador Bruno Barretto Gomide. -- São Paulo, 2013.

$150 \mathrm{f.}$;

Dissertação (Mestrado) - Programa de Pós-Graduação em Literatura e Cultura Russa Faculdade de Filosofia, Letras e Ciências Humanas da Universidade de São Paulo.

1. Dostoiévski, Fiódor 1821-1881. 2. Joseph Frank. 3. Biografias. 4. Eslavística. 5.

Ficção Russa I. Título. II. Gomide, Bruno Barreto. 


\section{Pelo Prisma Biográfico: Joseph Frank e Dostoiévski}

Dissertação de mestrado apresentada ao Programa de pós-graduação em Literatura e Cultura Russa do Departamento de Letras Orientais da Faculdade de Filosofia, Letras e Ciências Humanas da Universidade de São Paulo, aprovada pela Banca Examinadora constituída pelos seguintes professores:

Prof. Dr. Bruno Barretto Gomide Faculdade de Filosofia, Letras e Ciências Humanas Universidade de São Paulo

Orientador

Profa. Dra. Aurora Bernardini Faculdade de Filosofia, Letras e Ciências Humanas Universidade de São Paulo

Prof. Dr Marcelo Timotheo da Costa Universidade Salgado de Oliveira, UNIVERSO 
Para Ricardo e Aliette, meus pais 


\section{Agradecimentos:}

Agradeço à Fundação de Amparo à Pesquisa do Estado de São Paulo (FAPESP) as bolsas concedidas no país e no exterior, que possibilitaram a minha dedicação exclusiva a esta pesquisa.

Ao meu caro orientador, agradeço a paciência e as dicas valiosíssimas em todas as etapas do mestrado. Foi extremamente gratificante ter sido guiada nessa imersão nos temas russos por um professor ao mesmo tempo brilhante e atencioso.

Agradeço à Professora Irina Paperno a orientação atenta e o auxílio durante o meu estágio de pesquisa no exterior na Universidade da Califórnia, Berkeley (com ela aprendi que o rigor e a disciplina à moda russa são ótimos antídotos para os momentos de inércia e indecisão). Agradeço também às professoras Luba Golburt e Victoria Frede, que concordaram com a minha presença como aluna ouvinte nas suas aulas e à Anna Muza e Harsha Ram, também professores de Berkeley, a gentileza. Agredeço à Diane O. Thomposon as observações referentes ao meu trabalho feitas durante um almoço informal no BASSEES de 2012, que abriram os meus olhos para a relevância da biografia de Frank no meio acadêmico anglo-saxão, e à Tamara Djermanovic as palavras incentivadoras na ocasião daquele Congresso.

Agradeço ao professor Márcio Seligmann, responsável pelas aulas interessantíssimas que eu assisti no Instituto de Estudos da Linguagem (IEL) na Unicamp. $\mathrm{Na}$ Universidade de São Paulo, agradeço à Fátima Bianchi os ensinamentos sobre a literatura de Dostoiévski. Agradeço aos professores que compuseram a minha banca de qualificação, Aurora Bernardini e Marcelo Timotheo, as críticas e sugestões extremamente construtivas e determinantes para o desenrolar dessa pesquisa. Não poderia me esquecer dos funcionários do DLO, Jorge e Luís, que me socorreram nos momentos de apuro gerados pela minha desatenção a certos procedimentos burocráticos. Quero também expressar a minha gratidão aos meus incríveis colegas da Pós-graduação em Literatura e Cultura Russa, que tornaram menos solitários e mais alegres os anos de mestrado.

Não posso deixar de mencionar meus amigos queridos, sempre ao meu lado mesmo nos momentos de chatice aguda. Os amigos historiadores como eu, Carolina Kuk, Annelise Carvalho, Victor Sobreira, Carlos Ortiz, e outros. Também meus velhos amigos Julia Passos, Isabel Bernardes, Bia Falleiros, Bruno Cucio, André Goldfeder, Gustavo Simon, Pedro Nakano, Tayná Britto, Caio Marchi, Natália Fazzione, Tiago Frúgoli e muitos outros (que sinto por não citar os nomes para não me alongar demais), quero deixá-los cientes dos meus mais sinceros agradecimentos. Também agradeço aos meus colegas e amigos de Berkeley, que contribuíram para tornar inesquecíveis meus meses no exterior.

Agradeço aos meus pais, a quem dedico essa pesquisa e às minhas queridas avós e tias, de quem não esquecerei o esforço para a compreensão dos motivos aparentemente insondáveis que teriam me levado a optar por me trancar em bibliotecas e aprender uma língua tão difícil quanto o russo.

Last, but not least, gostaria de agradecer à Marguerite Frank e a Joseph Frank. Sou imensamente grata aos dois por terem me recebido em sua residência em Stanford, Palo Alto - Califórnia, para uma conversa sobre a minha pesquisa. Joseph Frank, que infelizmente já não está mais entre nós, além de ter me concedido uma tarde inesquecível, me presenteou com um excelente material de reflexão que aguçou a minha curiosidade intelectual e enriqueceu meu repertório cultural durante esses anos como estudante de mestrado. 
"O homem é um enigma. Esse enigma tem de ser decifrado, e se você levar a vida inteira para fazêlo, não diga que desperdiçou seu tempo; еи me ocupo desse enigma porque quero ser um homem"

Fiódor Dostoiévski 
ALMEIDA, Giuliana Teixeira de. Pelo Prisma Biográfico: Joseph Frank e Dostoiévski.

São Paulo: 2013, 150 f. Dissertação (Mestrado em Literatura e Cultura Russa) Faculdade de Filosofia, Letras e Ciências Humanas, Universidade de São Paulo.

\section{RESUMO}

Muitas biografias foram escritas sobre Fiódor Dostoiévski, nome central da literatura russa do século XIX. Dentre os títulos dedicados à vida do escritor russo destaca-se Dostoiévski de Joseph Frank, um grande esforço de investigação elaborado ao longo de quase três décadas. A obra escrita pelo scholar norte-americano consiste em uma síntese da história cultural da Rússia no século XIX, contexto no qual Dostoiévski viveu, além de um esforço de interpretação da ficção do romancista. Essa pesquisa visa analisar a biografia de autoria de Joseph Frank, assim como efetuar uma comparação entre essa obra e outras biografias importantes escritas sobre o escritor russo. Paralelamente, pretende-se investigar as questões teóricas e metodológicas concernentes ao gênero biográfico. Tendo em vista a grande repercussão da obra nas publicações norteamericanas, essa pesquisa também examinará de modo panorâmico a recepção da biografia de Frank nos Estados Unidos e os percursos da eslavística norte-americana nas últimas décadas.

Palavras-Chave: Dostoiévski; Joseph Frank; Biografias; Eslavística; Ficção Russa. 
ALMEIDA, Giuliana Teixeira de. Through the Biographical Prism: Joseph Frank and Dostoevsky. São Paulo: 2013,150 f. Dissertação (Mestrado em Literatura e Cultura Russa) - Faculdade de Filosofia, Letras e Ciências Humanas, Universidade de São Paulo.

\begin{abstract}
Many biographies have been written about Fyodor Dostoevsky, a prominent 19th century Russian literature novelist. Among all these titles, Joseph Frank's Dostoevsky stands out as a great synthesis of the Russian writer's life and era. Written along three decades, Frank's work recreates the Russian cultural history in the second half of the 19th century and proposes an interpretation for Dostoevsky's literary works. After this biography, Frank has become one of the most important North American's experts in Russian literature and Dostoevsky. This research aims to analyze this monumental biography, to compare this work with other biographies written about the thrilling life of Dostoevsky and to investigate the theoretical and methodological problems of the biography genre. Finally, considering the repercussion of Dostoevsky for the intellectual community of United States of America, we will also analyze the reception and the critiques of Frank's biography and the situation of the last decades of Slavic studies in that country.
\end{abstract}

Key Words: Dostoevsky; Joseph Frank; Biographies; Slavic Studies; Russian fiction. 
SUMÁRIO

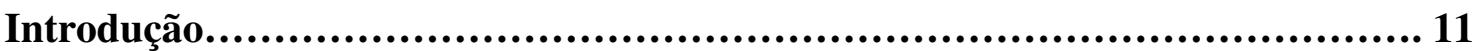

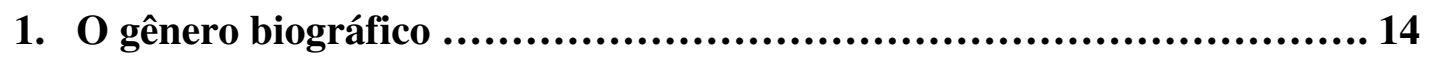

2. Fiódor Dostoiévski: uma vida hiperbiografável............................................... 41

3. Dostoiévski de Joseph Frank ...................................................................... 71

4. Frank, seus críticos e a eslavística norte-americana .................................. 109

Conclusão........................................................................................................................................ 134

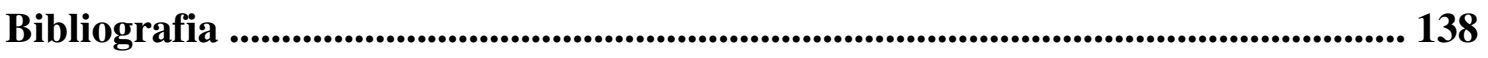




\section{Introdução:}

Fiódor Dostoiévski é um dos escritores russos que mais desperta a atenção dos estudiosos do mundo todo. É um grande desafio identificar um tema de pesquisa pouco explorado que envolva o grande romancista. Assim, a dificuldade em encontrar um caminho não tão percorrido desviou a nossa curiosidade investigativa para um filão muito rico que envolve a figura de Dostoiévski: as biografias. Muitas biografias foram escritas sobre a vida do escritor russo nos mais diferentes contextos temporais e espaciais. Em meio a essa infinidade de obras biográficas, Dostoiévski, de Joseph Frank, conquistou um destaque considerável.

Um aspecto distintivo da obra do pesquisador norte-americano é o método empregado, que pressupõe que os romances tornam-se inteligíveis na medida em que o contexto histórico no qual Dostoiévski viveu e produziu é descortinado. Para Frank, Dostoiévski é um escritor magistral por representar os grandes temas que sempre preocuparam a humanidade como, por exemplo, a existência da imortalidade, a importância da liberdade etc., nos termos das mais explosivas urgências da sua época, como o comportamento da geração radical de 1860, as condições de vida das classes desafortunadas dos bairros pobres de São Petersburgo, entre outros. O empenho na pesquisa histórica emprestou à biografia o alcance de uma obra de historiografia, e por isso Dostoiévski também pode ser lida como uma história cultural da Rússia do século XIX.

A opção por este método foi o que mais impressionou os colegas de Joseph Frank, uma vez que entre os norte-americanos a tradição crítica que considera os elementos externos à obra irrelevantes para o estudo e compreensão da mesma é muito 
arraigada. A aposta de Frank gerou um enorme interesse entre os estudiosos do assunto e foram produzidas sobre Dostoiévski numerosas resenhas críticas e artigos científicos. A recepção da biografia, muito favorável, lança luz sobre seus méritos e também sobre o status e a respeitabilidade do autor no seu meio acadêmico. Outra fonte de informações sobre Dostoiévski encontra-se na história da eslavística norte-americana, uma vez que a biografia não consiste somente em um empreendimento individual de um importante intelectual às voltas com o seu objeto de pesquisa, mas também em uma "radiografia", ou mesmo em um "termômetro" dessa eslavística da qual o seu autor é parte.

É importante ressaltar que o intuito de analisar adequadamente a obra de Frank esbarrou no desconhecimento das questões teórico-metodológicas pertinentes às biografias. Como será devidamente assinalado no primeiro capítulo desta dissertação, o gênero biográfico, apesar da sua notável popularidade, é pouco debatido e pensado na academia. O descaso pode ser parcialmente explicado pelas dificuldades intrínsecas à biografia, que a empurram para uma região fronteiriça entre as ciências humanas e a literatura. O compromisso com a verossimilhança e o aproveitamento das técnicas da ficção são características deste gênero que provocam tanto a desconfiança dos historiadores preocupados com as fontes documentais, quanto dos escritores movidos pela criatividade. Confinada neste "limbo" intelectual, a biografia permanece um objeto pouco debatido e pensado. No entanto, a escassez de obras teóricas destoa da enorme quantidade de biografias expostas nas estantes de livrarias, tanto no Brasil quanto em outros países, que exercem grande atração sobre os leitores no mundo todo. Um indício dessa atração pode ser apontado no elevado número de biografias disponíveis sobre a vida de Dostoiévski, como já assinalado. 
Tendo em vista esse panorama, para fazer frente ao silêncio que paira sobre a biografia, optamos por compor uma síntese da literatura crítica disponível sobre o gênero biográfico, visando a demonstrar que o mesmo pode oferecer um ponto de partida profícuo para futuras investigações em diversas áreas do conhecimento. Optamos também por discutir algumas das principais biografias escritas sobre Dostoiévski, tanto para compreender a diversidade intrínseca ao gênero, quanto para tentar localizar o lugar ocupado por Dostoiévski de Frank no interior desta tradição.

Em síntese, ao longo dos quatro capítulos que compõem esta dissertação, optamos por destrinchar a teoria existente sobre o gênero biográfico (capítulo 1, $O$ gênero biográfico); as diversas biografias disponíveis sobre a vida de Dostoiévski (capítulo 2, Dostoiévski: uma figura hiperbiografável); as particularidades da biografia da autoria de Joseph Frank (capítulo 3, Dostoiévski de Joseph Frank); e a opinião dos colegas eslavistas de Frank sobre a obra, assim como a história deste campo de estudos nos Estados Unidos (capítulo 4, Frank, seus críticos e a eslavística norte-americana).

Ao final desta dissertação, esperamos oferecer aos leitores uma análise da biografia escrita por Joseph Frank que faça justiça à sua importância e à centralidade na eslavística anglo-saxã. Almejamos também familiarizar os pesquisadores brasileiros e os interessados em geral com este estudioso que ocupa a linha de frente entre os teóricos dostoievskianos da atualidade. 


\section{O gênero biográfico}

Desde o seu surgimento na cultura ocidental, no século V a.C, a biografia resiste dentre os mais longevos e frutíferos gêneros literários. Nenhuma geração se esquivou do desafio biográfico e esta se incorporou a história da humanidade como um importante trunfo na luta inglória travada pelos homens contra a inevitabilidade da morte e as sombras do esquecimento.

A palavra grega BIO [vida] GRAFIA [escrita], em sua acepção etimológica, evoca o pressuposto de que um destino individual, enquanto uma continuidade, uma unidade determinada por duas datas - o dia do nascimento e o dia da morte - é possível de ser narrado. A biografia dependeu da escrita para constituir-se como gênero, pois somente com base em documentos escritos os homens começaram a narrar vidas que, por serem consideradas significativas, mereceram ser recontadas e comemoradas. Logo após o seu surgimento (no século $\mathrm{V}$ a.C como um gênero complementar à História), a biografia não teve grande prestígio, porque no contexto democrático da Grécia Antiga o indivíduo nada significava descolado da coletividade. $\mathrm{O}$ desenvolvimento do gênero biográfico deslanchou apenas um século mais tarde (IV a C.), quando o período helênico experimentou "um surto de informações de ordem biográfica nos epigramas funerários" $"$.

O despertar da biografia na época helenística aponta para uma nova batalha encampada pela humanidade: uma batalha contra o esquecimento, na qual se entrevê o desejo de imortalidade. Assim, da sua origem na Antiguidade até a época Moderna a biografia dedicou-se à narração das vidas de homens virtuosos. Estas eram poupadas do olvido por oferecerem modelos de comportamento e de virtudes às gerações vindouras.

\footnotetext{
${ }^{1}$ DOSSE, François. O Desafio Biográfico - Escrever uma Vida. São Paulo: Edusp, 2009, p. 124.
} 
Os valores cultivados eram os heroicos, e o regime de historicidade ao qual se relacionava esse gênero orientava-se pelo passado, com vistas, portanto, à reprodução dos modelos existentes no futuro. Dessa maneira, a linha divisória entre a verdade e a ficção não era tão rigorosamente demarcada, uma vez que o horizonte de expectativas dos apreciadores de biografias não compreendia senão a narração de uma vida exemplar, mesmo que o preço a ser pago por esse resultado fosse um breve flanar pelos bosques da ficção.

Durante o período medieval, o gênero sofre um leve desvio de rota, pois com a cristianização, os valores heroicos explicitados nas biografias são substituídos pelos valores religiosos e as hagiografias (ou vidas de santos) tomam para si a função de narrar vidas exemplares. O Renascimento, com toda a sua sede pelas fontes dos antigos, retoma os valores heroicos, porém revela uma tensão intrínseca à época moderna: ao mesmo tempo em que se caminha para a valorização do indivíduo em oposição ao seu eclipsar da época medieval, passa-se a esperar desse indivíduo uma relação com o universal. Nas palavras do historiador François Dosse, "é pela capacidade de absorver os valores coletivos, de encarná-los em um percurso singular, que a vida dos indivíduos encerra um sentido maior que a mera equação pessoal e conquista uma glória duradoura aos olhos de outrem, por meio do reconhecimento",2. Mesmo com o abalo da noção de herói, o modelo de biografias obedecido durante o Renascimento continuará sendo o dos Antigos e a época moderna como um todo não ousará para além de uma escrita equilibrada entre a vida exemplar e a facécia singular.

O século XVIII trará consigo a crise definitiva da figura do herói. "Seu caráter semidivino passa a ser contestado, em nome da razão, pela filosofia das Luzes. Os valores guerreiros que o herói encarna vão aos poucos sendo tidos como coisa

\footnotetext{
${ }^{2}$ Idem, p. 154 .
} 
ultrapassada numa sociedade desejosa de paz"3. Dessa maneira, a crise da figura do herói empurra o gênero biográfico para a reconstituição da vida dos grandes homens. $\mathrm{O}$ grande homem, diferentemente do herói, é retratado pelos biógrafos como um homem detentor de virtudes e defeitos como todos os outros homens, porém com uma particularidade fundamental que o distingue dos demais: um feito importante, uma obra prima, algo memorável e relevante realizado durante a sua trajetória de vida. Se no século XIX os grandes homens eram geralmente nomes destacados da política nacional, tendo em vista que a nação era o grande referencial de identidade coletiva, posteriormente “a evolução do 'grande homem' nos tempos modernos, amplificada por sua capacidade de criar e entreter uma relação especial com a dimensão do belo, ensejou o deslocamento da empresa biográfica para o mundo dos artistas sob todas as formas de expressão"4. Assim, escritores, pintores, músicos, atores e atrizes, entre outros, assumiram certo protagonismo nas biografias, principalmente no decorrer do século $\mathrm{XX}$.

Mesmo após a resolução do problema da crise do herói e da eleição de novos objetos para a empreitada biográfica, a biografia não conhecerá dias mais luminosos durante o século XIX, não por acaso o século da disciplinarização da História. Esta nova disciplina começa a valer-se de outras lógicas, mais coletivas e sociais, e inicia um grande debate acerca da relevância das ações individuais no curso da História. O novo regime de historicidade gestado pelo Positivismo e pelo Marxismo, entre outras filosofias da História, inverte aquele cultivado pelos antigos e o futuro passa a orientar o passado, deslegitimando assim a busca por modelos para o porvir em um tempo que já passou.

\footnotetext{
${ }^{3}$ Idem, p. 166.

${ }^{4}$ Idem, p. 183.
} 
Por conseguinte, durante todo o século XIX, a biografia foi relegada a uma função acessória da História e rebaixada ao segundo escalão das práticas científicas. Transformada em um gênero menor, a biografia converteu-se em um métier de jornalistas, ou em uma atividade de polígrafos menos gabaritados. O eclipse ao qual foi relegado o gênero perdurará até praticamente as últimas décadas do século XX. Não se deve perder de vista que o século XX é o século do triunfo da individualização, fenômeno que se aprofunda ainda mais no século seguinte (XXI). A valorização extrema do indivíduo eleva-o ao posto de fonte de inspiração e a objeto primordial de reflexão, favorecendo dessa maneira o redespertar do gênero biográfico.

Assim, o sol volta a brilhar no terreno da biografia, e com força a partir dos anos 1980 do século XX. É no decorrer desta década que os setores mais refratários ao gênero - a Academia, as editoras de maior prestígio, em suma, os meios intelectualizados - começam a mudar de opinião. Se até a metade da década de 80 a biografia foi absolutamente desprezada pelos eruditos e acadêmicos, que a consideravam irrelevante para o avanço do trabalho científico, nos últimos anos a situação alterou-se, ainda que timidamente. O historiador François Dosse estabelece uma data para o movimento de redescoberta das "virtudes de um gênero que a razão gostaria de ignorar" ${ }^{\circ}$ o ano de 1985. Segundo o historiador, foi nesse ano que na França o Livres-Hebdo, o hebdomadário profissional das publicações, "consagrou a única seção especializada até então existente às biografias, e a pesquisa publicada revelou a simpatia de todos os editores, inclusive os mais sérios pelo gênero biográfico. Só em 1985, duzentas novas biografias foram publicadas por cinquenta editoras, cujo otimismo parece eufórico nesse campo, enquanto nos outros é acentuadamente tímido"6. Esse

\footnotetext{
${ }^{5}$ Idem, p. 16.

${ }^{6}$ Idem, p. 16.
} 
otimismo se manteve pelos anos subsequentes e após esse empurrão inicial dado pelos editores franceses a taxa de lançamento de biografias cresceu $66 \%$ em quatro anos.

Na década de 1990 esse crescimento perdurou e na França o Círculo de livrarias contabilizou a publicação de 611 biografias no ano de 1996 e de 1043 no ano de 1999. Mas esse fenômeno não é particular ao caso francês, pois como assinala o historiador brasileiro Benito Bisso Schmidt, "o retorno da biografia é um movimento internacional"7 e perceptível em muitos países. Na Inglaterra, uma pesquisa de opinião realizada no ano de 1994 apontou que entre as pessoas que liam um livro por mês, 19\% preferiam as biografias. Nos Estados Unidos, o biógrafo Stephen Oats citou em seu livro uma pesquisa realizada pela Library of Congress que informou que entre os entrevistados, a maioria havia optado por ler biografias nos seis meses anteriores à realização da pesquisa do que qualquer outro gênero literário ${ }^{8}$.

Já no nosso país, segundo dados apresentados por Schmidt, o Catálogo brasileiro de publicações apontou no ano de 1994 um crescimento de 55\% do gênero em relação ao ano de $1987^{9}$. No Brasil, o sucesso da biografia foi impulsionado pela publicação da narração das vidas de grandes artistas e celebridades nacionais, como por exemplo, O Furacão Elis (1985) e Cazuza, só as mães são felizes (1997), ambos de Regina Echeverria, sem contar as obras dos dois principais biógrafos do país - Fernando Moraes e Ruy Castro- autores que se debruçaram sobre as vidas de Garrincha, Carmem Miranda, Paulo Coelho, entre outros.

\footnotetext{
${ }^{7}$ SCHMIDT, Benito Bisso. "Construindo Biografias- Historiadores e Jornalistas: Aproximações e Afastamentos" Revista Estudos Históricos, Vol. 10, $\mathrm{N}^{\circ} 19,1997$, p. 3-22 disponível em http://virtualbib.fgv.br/ojs/index.php/reh/article/viewFile/2040/1179

${ }^{8}$ BACKSCHEIDER, Paula R. Reflections on Biography. New York: Oxford University Press, 1999, p. XIII.

${ }^{9}$ SCHMIDT, Op. Cit. p. 3.
} 
Portanto, a atração do público leitor pelas biografias, principalmente na conjuntura atual, é algo digno de nota. E ainda que os meios intelectualizados também tenham se voltado para a biografia, o histórico de desinteresse sobre o gênero desembocou numa ausência de reflexão crítica e discussão teórica que está longe de ser superada. A escassez de literatura crítica disponível suscita a questão: uma vez que se publicam e se consomem tantas biografias, como é possível que não existam parâmetros para se discutir a qualidade ou ausência de qualidade dessas obras? E como os biógrafos conseguem se aventurar em um gênero cujas fronteiras não estão claramente delimitadas? Um simples passar de olhos sobre as resenhas críticas publicadas na imprensa sobre biografias recém-lançadas oferece subsídio para a afirmação de que o gênero é tão pouco estudado que nem os parâmetros para avaliar se um empreendimento biográfico foi ou não bem realizado estão consolidados. Como escreveu Carl Rollyson, "to the professional reviewer it is merely a story to be retold as if the reviewer wrote the biography" ${ }^{\prime 10}$. Segundo o importante estudioso do biografismo (e autor de biografias clássicas, como a de Henry James) Leon Edel, a biografia é "a child of individual talents", que sofre "from a lack of definition, a laxity of method" e é legítimo afirmar que "there exists [I'm sorry to say], no criticism of biography worthy of the name"11.

Também no Brasil, o boom da biografia não coincidiu em proporção com o interesse dos meios intelectualizados pelo gênero. Apesar do sucesso editorial e do apreço do grande público, a biografia ainda é pouco discutida e pensada no universo da academia. Apenas timidamente este gênero vem despertando a atenção dos acadêmicos brasileiros, despontando como inspiração ou solução como método qualitativo para trabalhos científicos nas áreas da sociologia, educação, psicologia social, antropologia e

\footnotetext{
${ }^{10}$ ROLLYSON, Carl. A Higher Form of Cannibalism? Adventures in the art and politics of biography. Chicago: Ivan R. Dee, 2005, p. 59-60.

${ }^{11}$ EDEL, Leon. Writing Lives. Principia Biographica. New York/ London: W. W. Norton and Company, 1984, p.24-31.
} 
como objeto de estudo para historiadores, linguistas, críticos literários e filósofos. Mas, mesmo com essa nova tendência, o espaço destinado à biografia é o do mercado e da indústria cultural e, por conseguinte, não é por acaso que as biografias de artistas e personalidades famosas destacam-se entre os lançamentos editoriais brasileiros. A lógica mercadológica que enredou o gênero biográfico é um reflexo da superestrutura da sociedade da informação, na qual a valorização do indivíduo converge para o culto à celebridade.

É importante ressaltar que o negócio lucrativo das biografias de artistas (músicos, escritores, como também pensadores, intelectuais, filósofos) adquire no nosso tempo outra função para além de uma saborosa fonte de anedotas sobre as intimidades desses personagens: essas biografias são consideradas muitas vezes o caminho mais adequado para a compreensão do sentido da obra destes artistas. É possível se intuir que o sucesso das biografias de artistas e pensadores atualmente seja um sintoma desta concepção, que considera o conhecimento da vida de alguém um caminho, ou mais propriamente um atalho, para o entendimento das obras por ele produzidas. E, muitas vezes, creditam-se a estas obras biográficas a faculdade de anulação do percurso comum do estudo sistemático do significado da produção artística/intelectual dos sujeitos biografados. A questão que vem à tona é velha conhecida do universo biográfico: a vida de um indivíduo pode elucidar a sua obra?

No caso das biografias de escritores, a crença de que a vida explica a obra pode ser facilmente situada por meio da apreciação de um "subgênero" do gênero biográfico: as biografias literárias. As biografias literárias convencionais estiveram por muito tempo no centro da história literária clássica que, segundo François Dosse, "teria transmitido o patrimônio literário essencialmente pelo ângulo do liame entre a vida e a obra do escritor. O mais das vezes, o sentido da obra é deduzido das peripécias da vida, 
e a biografia dos escritores está no próprio cerne da inteligibilidade literária"12 . Assim, o sentido da obra estaria encerrado no seu autor. Alguns lugares-comuns dessas biografias literárias clássicas são a inclinação dos biógrafos a retratarem a trajetória do escritor como se desde o nascimento este já estivesse predestinado para a sua função, ou ainda aquilo que foi denominado como "vidobra"- a crença em que o autor está em seus livros e não em sua vida.

A solução biográfica da "vidobra" sofreu inúmeras críticas e no presente os autores de biografias literárias dificilmente adotam como método a narração da vida de um escritor através do estabelecimento de uma correspondência necessária entre os personagens e as situações que aparecem nas obras ficcionais com as experiências de fato vivenciadas pelo mesmo durante a vida. André Maurois, autor de Aspects de La Biographie, uma referência nos estudos teóricos da biografia, já adverte neste livro do início do século XX o quanto é despropositado esse modo de escrever biografias literárias e aponta para o perigo que os biógrafos correm de elaborarem hipóteses inverossímeis ao tomar as obras ficcionais dos escritores como ricas fontes de informações biográficas.

O controverso subgênero das biografias literárias encontrou resistência e desconfiança também por parte de alguns escritores. Vladímir Nabókov, por exemplo, defendeu que a vida de escritores não deveria e nem poderia ser biografada, pois, de acordo com seu ponto de vista, os biógrafos não passavam de "psycho-plagiarists" "13 que utilizavam a vida do escritor em questão para completar e preencher o vazio das suas próprias vidas. O julgamento de Nabókov refletia a opinião hegemônica da crítica literária norte-americana do século XX que, encabeçada pela escola teórica do New

\footnotetext{
${ }^{12}$ DOSSE, Op. Cit., p. 80.

${ }^{13}$ EDEL, Op. Cit., p. 20-21.
} 
Criticism, considerava a análise da obra de um escritor pelo viés biográfico irrelevante e equivocada. Segundo os preceitos dessa escola, que seriam mais tarde reforçados pelo estruturalismo, "it is the work not the life(...) that counts"14.

A relação do gênero biográfico com a literatura, porém, vai muito além do polêmico "subgênero" da biografia literária. A biografia, cuja função consiste na narração da vida de um indivíduo, recorre conscientemente às técnicas que pertencem à literatura. Como afirmou com uma pitada de humor o filósofo francês Jean-Paul Sartre, "Nothing happens while you live. The scenary changes, people come in and go out, that's all. There are no beginnings... But everything changes when you tell about life"15. O trabalho do biógrafo que consiste em organizar os eventos de uma vida humana pressupõe a competência da narração com arte para evitar que o produto final se transforme em uma reprodução disparatada e pouco fluida de todas as fontes primárias consultadas. Transmitir coerência ao texto é o que se espera do autor de uma biografia, pois como afirmou David Lowenthal "the past we reconstruct is more coherent than the past was when it happened. (...) Narrative exigencies magnify these differences"16. E, uma vez que a narrativa é um imperativo na representação de uma vida, esta invariavelmente se ampara em técnicas ficcionais - toda boa narrativa se inclina para a ficção.

É muito fácil encontrar na literatura disponível sobre o gênero biográfico afirmações como a de Leon Edel, segundo a qual na escrita de uma biografia "the biographer borrow some of the techniques of fiction without lapsing into fiction" $"$. Muitos estudiosos do assunto defendem a existência dessa proximidade entre a biografia

\footnotetext{
${ }^{14}$ Idem, p. 21.

${ }^{15}$ NADEL, Ira Bruce. Biography. Fiction, Fact and Form. The MacMillan Press LTD, 1984, p X.

${ }^{16}$ LOWENTHAL, David. The Past is a Foreign Country. Cambridge: Cambridge University, 1990, p. 234.

${ }^{17}$ EDEL, Op. Cit., p 202.
} 
e gêneros ficcionais. Esse flerte com a ficção, no entanto, é delicado no contexto do gênero biográfico porque o outro lado da moeda, ou seja, a outra função do gênero (para além de narrar uma vida) é retratar somente o que se pode saber sobre ela por meio dos "fatos", ou das fontes documentais disponíveis, o que exclui a legitimidade de qualquer invenção.

Assim, a biografia se situa em um sinuoso espaço entre os critérios de verossimilhança estipulados pela disciplina histórica e a invenção ficcional, e por essa razão pode ser definida como um gênero que abala a barreira que geralmente se ergue entre a literatura e a dimensão científica das ciências humanas. Segundo François Dosse, “(...) O gênero biográfico encerra o interesse fundamental de promover a absolutização da diferença entre um gênero propriamente literário e uma dimensão puramente científica - pois, como nenhuma outra fonte de expressão, suscita a mescla, o caráter híbrido, e manifesta assim as tensões e as conivências existentes entre a literatura e as ciências humanas" $" 18$.

Do ponto de vista das ciências humanas, mais especificamente da disciplina da História, é no momento da elaboração do texto biográfico que as dificuldades surgem para o biógrafo/historiador comprometido com a missão de narrar uma história verossímil. Inúmeras são as lacunas documentais e incontáveis são as perguntas sem respostas. Na reconstituição de uma trajetória humana, a inexistência de documentos concernentes a muitos dos aspectos da vida como os pensamentos cotidianos, as conversas corriqueiras, as intenções por trás dos atos etc., exigem do biógrafo certa dose de ousadia criativa e uma nova postura diante das técnicas argumentativas conhecidas no campo da História. Essa nova postura pode significar um pequeno passo em direção aos domínios da literatura.

\footnotetext{
${ }^{18}$ DOSSE, Op. Cit., p. 18.
} 
Dessa forma, a biografia sintetiza algumas das mais importantes questões metodológicas da historiografia contemporânea. Nas palavras de Giovanni Levi, “(...) a biografia constitui na verdade o canal privilegiado através do qual os questionamentos e as técnicas peculiares da literatura se transmitem à historiografia. Muito já se debateu esse tema, que concerne sobretudo às técnicas argumentativas utilizadas pelos historiadores. Livre dos entraves documentais, a literatura comporta uma infinidade de modelos e esquemas biográficos que influenciariam amplamente os historiadores"19.

Já da perspectiva do campo da literatura, a existência do limite documental para a narração da vida em questão também representa um empecilho para a livre criação. Virginia Woolf, que escreveu três obras "biográficas", sendo duas delas ficcionais (Orlando e Flush), e uma não-ficcional (A vida de Roger Fly) indagou com uma pitada de humor "How can one cut loose from facts, when there they are, contradicting my theories?"20 . O desafio do ponto de vista literário é unir a não-ficção com a criatividade, esferas que normalmente não se interpenetram. Uma vez que, no caso do gênero biográfico, a narração literária e as técnicas ficcionais são as grandes responsáveis por organizar os "fatos", surge tanto a dificuldade de distinguir a biografia de qualquer outra obra de ficção, quanto a de inseri-la entre os trabalhos que obedecem aos critérios “científicos" da pesquisa histórica.

Para demarcar essa peculiaridade do gênero biográfico - o objetivo de representar uma história não-ficcional - os estudiosos do biografismo têm se valido da ideia de que um "pacto", "contrato" ou "acordo" é invariavelmente firmado entre o leitor e o autor de uma biografia. A tese de pacto remete ao estudo realizado por Philippe Lejeune sobre a autobiografia Le pacte autobiographique (1975), que se tornou

\footnotetext{
${ }^{19}$ LEVI, Giovanni "Usos da biografia" IN: FERREIRA, Marieta de Moraes e AMADO, Janaina (orgs). Usos e Abusos da História Oral. Rio de Janeiro: Editora FGV, 2000, 3. ed., p. 168.

${ }^{20}$ NADEL, Op. Cit., p. 5.
} 
uma obra clássica sobre esse gênero de escrita. Em linhas gerais, a tese defendida por Lejeune é a de que a categoria do autor é imprescindível para se pensar o gênero autobiográfico, que consiste em um relato retrospectivo escrito em prosa que uma pessoa real faz de sua vida. Esse relato enfatiza o que ocorreu e reconstitui a história da personalidade do autor do texto. $\mathrm{O}$ conceito de identidade desponta como fundamental e pode ser comprovado através do nome próprio - uma existência civil passível de ser constatada empiricamente. Dessa maneira, personagem, narrador e autor necessariamente se identificam no relato autobiográfico. $\mathrm{O}$ pacto que se estabelece entre o autor e o leitor é um pacto de compromisso com a verossimilhança, que assume a forma de um contrato que o primeiro oferece ao segundo através da capa da sua autobiografia assinada com o seu nome. Assim, o carimbo que confere autenticidade ao pacto de busca da narrativa verossímil é a assinatura (nome próprio) do autor da autobiografia.

A ideia de pacto oriunda dos estudos sobre a autobiografia foi reelaborada por autores preocupados com o problema da relação entre a verossimilhança e a escrita biográfica. É o caso do escritor brasileiro Cristovão Tezza, que analisa o tema em conferência apresentada no XI Congresso Internacional da ABRALIC (2008) intitulada Literatura e Biografia. Para Tezza, assim como o que ocorre com a autobiografia, “(...) no caso da biografia, a intencionalidade da mão que escreve instala-se em cada palavra da voz que fala no texto, de uma forma completa e absoluta. Esse é um acordo de princípio estabelecido pela onipresença do 'mundo dos fatos'. E, de certa forma, é com relação a essa férrea disposição do autor do texto que julgamos a qualidade de uma biografia”, pois, ainda nas suas palavras, “(...) o império dos fatos deve ser soberano. Ou, melhor dizendo, a intenção sincera de representá-lo mesmo sabendo que essa é 
sempre uma tarefa de Sísifo"21. Dessa forma, um pacto, ou acordo também se estabelece entre o biógrafo e o leitor da biografia nas mesmas bases do pacto autobiográfico: "a garantia de que o que se narra é, em qualquer caso, tentativa de representação fiel da realidade",22.

Essa mesma ideia aparecerá com outras denominações na bibliografia disponível sobre o assunto. Paula Backscheider, no livro Reflections on Biography, emprega o termo contrato (contract) e utiliza a metáfora de um passeio turístico para exemplificar a postura do leitor que confia no biógrafo com quem o contrato foi firmado. Segundo Backscheider, o leitor sente-se como se estivesse sendo conduzido em um tour por um excelente motorista que conhece como a palma da mão a paisagem geográfica, os fatos históricos e o significado atual do local turístico visitado. Ainda segundo a autora, o que justificaria uma quebra de contrato é a percepção por parte do leitor de que um dado apresentado como legítimo está na verdade incorreto, pois "the biographer must know what he or she is talking about and tell it accurately, fairly, and with comprehension of related contexts. Rightly, a few mistakes in such things as dates, names and locations of squadrons on a battle field will throw the accuracy and, therefore, value of the entire work into question",23.

Para Backscheider, o ato de selar um contrato com o biógrafo é também a única maneira razoável de fazer frente a uma variante intrínseca à biografia que entra em conflito com o objetivo do gênero, que é retratar uma história verossímil aproximandose o máximo possível dos fatos históricos. Esta variante crucial é denominada pela autora de "voice" - a voz do biógrafo. Esta voz, no entanto, dificilmente é percebida,

\footnotetext{
${ }^{21}$ TEZZA, Cristovão. "Literatura e Biografia". Conferência apresentada no XI Congresso Internacional da ABRALIC - Tessituras, Interações e Convergências. São Paulo, USP, 16 jul. 2008, p. 7.

${ }^{22}$ Idem, p. 8.

${ }^{23}$ BACKSCHEIDER, Op. Cit., p. 10.
} 
pois se por um lado o biógrafo é a parte mais poderosa entre todas as envolvidas em uma biografia, por outro lado é mais discreta. O biógrafo é quem inventa através da seleção e organização dos materiais, é quem estabelece as relações de causa e efeito, é quem determina o que foi mais ou menos importante na vida do sujeito biografado (que muitas vezes foi alguém que ele nem mesmo conheceu).

E, como se não bastasse, o ato de escrever uma biografia não se esgota em um processo puramente intelectual, pois é fundamental que o biógrafo cultive o que alguns autores denominaram como a qualidade da empatia ${ }^{24}$ - "the ability not only to sympathize with others human beings, but also to put ourselves in their places" ${ }^{25}$. É muito difícil que a relação entre sujeito e objeto (sendo no caso da biografia uma relação entre sujeito-sujeito) se estabeleça de forma objetiva e distanciada, pois o trabalho do biógrafo, como afirmou Leon Edel, "has to deal with emotions and to discover the emotional content of some of its materials" ${ }^{26}$. Todo esse envolvimento que a escrita de uma biografia demanda abre margem para que o leitor muitas vezes identifique no resultado do trabalho os amores ou ódios do biógrafo, alguns julgamentos, omissões propositais, aditamentos duvidosos, enfim, as opiniões e ideologias do autor imbricadas na narrativa. Como afirmou André Maurois, "l'historien ne peut toujours avoir l'esprit libre et le biographe moins encore; Il est homme; ses herós lui peuvent inspirer des amours et des heines qui troublent parfois son jugement",27.

Porém, ao mesmo tempo em que certo grau de envolvimento emocional com o sujeito biografado é determinante para o sucesso da empreitada biográfica, por outro

\footnotetext{
24 Na definição do Novo Dicionário Básico da Língua Portuguesa Aurélio, São Paulo: Nova Fronteira,1988: "Tendência para sentir o que sentiria caso se estivesse na situação e circunstância experimentada por outra pessoa".

${ }^{25}$ ROLLYSON, Op. Cit., p. 59.

${ }^{26}$ EDEL, Op. Cit., p. 40.

${ }^{27}$ MAUROIS, André, Aspects de la Biographie. Paris: Au Sans Pareil, 1928, p. 22.
} 
lado este envolvimento não deve deslizar para a identificação do biógrafo com a pessoa sobre quem ele escreve. É nessa linha tênue entre a empatia e a identificação que reside um dos grandes desafios oferecidos pelo gênero biográfico. O processo de identificação do biógrafo com o seu biografado, seguido da revelação de si na biografia dedicada à outra pessoa é algo que "is in reality at the core of modern biography, and it explains some of its most serious failures" ${ }^{28}$. Esta afirmação é valida porque os biógrafos da atualidade normalmente se dedicam à escrita de biografias conscientes do envolvimento com o objeto e muitas vezes procuram agregar valor à experiência biográfica considerando que: “o Si (Ipse) se constrói, não pela repetição do mesmo (Idem), mas pela relação com o outro, [e dessa forma] a escrita biográfica está bem próxima do movimento em direção ao outro e da alteração do eu rumo à construção de Si transformado em outro" 29 . Assim, o conhecimento do outro normalmente abre portas para o autoconhecimento, e nessa chave a atividade biográfica é um instrumento de transformação de si através do discurso sobre o outro - é um caminho enviesado de cura pela palavra, justamente porque a palavra não diz nada sobre si e tudo sobre o outro.

Portanto, uma das primeiras variáveis consideradas por muitos autores de biografias é o envolvimento com o biografado e, em casos extremos, o processo de identificação. Quando o envolvimento desemboca na identificação, o biógrafo tende a falar diretamente de si por meio do sujeito biografado e há casos em que alguns esboçam as suas autobiografias nas biografias de outrem. Nestas situações é possível que a qualidade da biografia fique comprometida, principalmente quando o processo de identificação obstrui o manejo dos fatos com base no compromisso com a

\footnotetext{
${ }^{28}$ EDEL, Op. Cit., p. 29.

${ }^{29}$ DOSSE, Op. Cit., p. 12.
} 
verossimilhança, impedindo o biógrafo, por exemplo, de apontar na sua biografia os defeitos, as falhas de caráter, as acusações existentes contra o biografado etc.

Ou seja, nem a idealização nem a depreciação do sujeito biografado deveriam aparecer na obra como o resultado da intromissão das emoções do biógrafo na empreitada biográfica. O ímpeto de heroicizar, no entanto, tende a ser o mais comum, pois como afirmou Paul Murray Kendall, “a biography may take a dozen years or more to write. Who would be willing, who would be able to spend that much time with a man for whom he had no feelings"30. Já Sigmund Freud aponta o efeito contrário, pois afirma que apesar do biógrafo jamais desejar retirar o biografado (que é denominado por Freud de herói) do pedestal, ele por outro lado almeja aproximá-lo de nós, meros mortais. E, na opinião de Freud, "it still tends in effect towards degradation",31.

Por fim, é fato que o "herói" em questão, segundo a denominação de Freud, é sempre alguém cuja trajetória da vida do começo ao fim é conhecida, daí a impossibilidade de passar ao largo do problema da vantagem retrospectiva da qual se favorece o biógrafo. E normalmente é o pressuposto do "resultado" de uma vida que empurra um autor para a escrita de uma obra biográfica. No caso de biografias de escritores, por exemplo, aquele que decide escrever a biografia de Dostoiévski tem em mente retratar a vida de um dos nomes mais importantes da literatura universal. É o Dostoiévski escritor que captura a intenção do biógrafo, e a partir desse constructo, ele se debruça sobre o homem para entender o percurso que levou Dostoiévski a se tornar o grande romancista. Mas, nesse movimento, é muito tentador para o biógrafo, conhecendo a grandeza artística de ficcionista do seu biografado, procurar indícios do

\footnotetext{
${ }^{30}$ KENDALL, Paul Murray. The Art of Biography. New York, W. W. Norton \& Company, inc. 1965, p. 16.

${ }^{31}$ FREUD, Sigmund, "Art and Literature" IN: O'CONNOR, Ulick. Biographers and the Art of Biography. Dublin: Wolfhound Press, 1991, p. 45.
} 
escritor no jovem aluno do instituto de engenharia, por exemplo, que Dostoiévski também foi.

É por essa razão que questões como a levantadas na obra de Lowenthal - “can we really be far to the men of the past? (...) Knowing what they could not know? Can we, indeed, understand them at all... with our minds prepossessed by a knowledge of the result?"32 - não podem deixar de ser colocadas para o biógrafo. Vai na mesma direção a advertência de Paul Murray Kendal, que afirma que "it is easy to see that what is the unknown future for the subject is the well-known past for the biographer; and it is easy to say that the biographer must use the advantage of this difference but not take advantage of it" ${ }^{33}$. O biógrafo deve ter essa vantagem retrospectiva sempre em mente como um aditivo que traz consigo graves perigos para o resultado do texto biográfico.

Assim, quando todas essas variáveis vêm à tona - a voz do biógrafo, o processo de identificação, o olhar viciado que pode elevar ou depreciar o sujeito biografado, a vantagem retrospectiva etc. - a biografia assume os contornos de um gênero inviável, incapaz de retratar uma vida de maneira verossímil. Mas, se o biógrafo não existisse, ou pudesse ser um sujeito neutro, imparcial, objetivo, será que as biografias nos ofereceriam retratos bem focados de vidas humanas? Uma das maiores promessas do gênero biográfico é a de que ele pode entregar ao leitor "the essential person and that there is a core personality, the 'real me', which we will find if only we dig deep and long enough" "34. A dúvida que emerge é "what is this "real me'? Could we explain it about ourselves? What, in fact, is personality?"35

\footnotetext{
${ }^{32}$ LOWENTHAL, Op. Cit., p. 217.

${ }^{33}$ KENDALL, Op. Cit., p. 16.

${ }^{34}$ NADEL, Op. Cit., p. 180.

${ }^{35}$ BACKSCHEIDER, Op. Cit., p. 93.
} 
Portanto, conhecer a fundo uma pessoa é uma ambição ilusória, pois, parafraseando Maurois, os homens são "enigmas perigosos". Ainda mais na época contemporânea, na qual impera a desconfiança do indivíduo acerca da profundidade do conhecimento que ele detém sobre ele próprio, principalmente após o advento da psicanálise, que lançou a advertência de que até mesmo o ego não é senhor em sua própria casa. É por essa razão que, segundo Maurois, "les écrivains de notre temps aient, plus que les esprits qui les ont precedes, le sens de la complexité et de la mobilité des êtres humaines et moins qu'eux le sens de leur unité",36. E essa compreensão foi pioneiramente esboçada nas obras literárias- é na literatura que se aprofunda a ideia de que o homem não é um ser coerente, uma unidade, uma totalidade. Na visão desse autor, em virtude dessa transformação que se evidencia na literatura - principalmente na literatura do século XIX, nas obras de Fiódor Dostoiévski - e que se enraíza no século XX com o surgimento da psicanálise, o sentimento da complexidade da personalidade humana passa a dominar as concepções acerca do homem.

Giovanni Levi assinala que o debate sobre a pertinência de se escrever a vida de um indivíduo data do século XVIII, época na qual surge o primeiro romance moderno, que segundo esse autor é Tristram Shandy, de Sterne, obra que pioneiramente apresenta uma biografia individual de maneira fragmentada. As contradições da identidade se fazem conhecer pelo leitor através do recurso ao diálogo, que na obra é travado entre Tristram (a personagem), o autor e o leitor. As inovações de Sterne terão continuidade na obra de Diderot, principalmente em Jacques o fatalista, no qual novamente o escritor recorre ao diálogo para transmitir ao leitor as dificuldades envolvidas na tentativa de se captar a essência de um indivíduo. Dessa vez o diálogo é estabelecido entre o jovem Jacques e seu velho mestre, que trocam também de papéis no decorrer da obra.

${ }^{36}$ MAUROIS, Op. Cit., p. 32, 33. 
Outro autor do século XVIII que lançará mão do diálogo para resolver a dificuldade de comunicar a "verdade" sobre si é Rousseau, que escreve as Confissões e que, insatisfeito com a acolhida que a obra recebe, redige posteriormente, dessa vez na forma "dialogal” (ou “dialógica”), Jean-Jacques julga Rousseau. Nas palavras de Levi, "Para Rousseau, assim como para Diderot ou Sterne (e anteriormente Shaftesbury, que foi talvez o inspirador dessa solução), o diálogo não era apenas o meio de criar uma comunicação menos equívoca; era também uma forma de restituir ao sujeito sua individualidade complexa, livrando-o das distorções da biografia tradicional que pretendia, como numa pesquisa etimológica, observá-lo e dissecá-lo objetivamente"37.

Essa nova seara que começa a ser explorada na literatura do século XVIII é definitivamente desbravada no século XIX, mais especificamente por meio da pena do grande escritor russo Fiódor Dostoiévski. Como já mencionado, André Maurois, no livro Aspects de La Biographie chama a atenção para esse ponto. Na sua visão, a complexidade do homem surge com toda a força na literatura russa do século XIX, mais especificamente nas obras de Fiódor Dostoiévski, nas quais "commence à reparaitre l'idée d'une multiplicité vivante á l'intérieur d'une même ame"38.

Como Bóris Schnaiderman ressaltou a partir das ideias do importante crítico soviético Mikhail Bakhtin, autor de Problemas da Poética de Dostoiévski, que hoje figura entre os estudos clássicos dedicados à produção literária do autor russo, "as personagens de Dostoiévski não 'vivem uma vida biográfica', isto é, não 'nascem, passam a infância e a juventude, casam-se, geram filhos, envelhecem e morrem', pois o

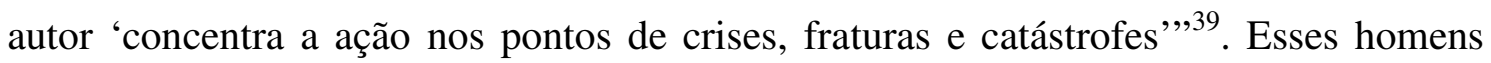

\footnotetext{
${ }^{37}$ LEVI, Giovanni "Usos da biografia" IN: FERREIRA, Marieta de Moraes e AMADO, Janaina (orgs) Op. Cit.,. p. 172.

${ }^{38}$ MAUROIS, Op. Cit., p. 37.

${ }^{39}$ SCHNAIDERMAN, Boris, IN:. Dostoiévski, Fiódor. O Idiota; tradução de Paulo Bezerra; desenhos de Oswaldo Goeldi. São Paulo: Ed 34, 2010, $3^{\circ}$ ed.
} 
aquém de uma vida "biográfica" têm as suas personalidades indecifráveis e imprevisíveis reveladas através do recurso ao diálogo, método narrativo recorrentemente empregado nos momentos críticos peculiares da obra dostoievskiana.

Mikhail Bakhtin cunhou o conceito de "romance polifônico" para explicar a inovação artística criada por Dostoiévski. Na visão do autor de Problemas da Poética de Dostoiévski, o escritor russo inventou um novo tipo de romance, diferente de tudo o que o precedeu cuja peculiaridade fundamental é "a multiplicidade de vozes e consciências independentes e imiscíveis e a autêntica polifonia de vozes plenivalentes" 40 , ou seja, heróis cujas vozes se estruturam como a do autor do romance comum, e que dessa maneira não são "apenas objetos do discurso do autor, mas os próprios sujeitos desse discurso diretamente significante" ${ }^{״ 1}$. Assim, torna-se impossível para o leitor encontrar no romance uma perspectiva unificadora, uma voz (que no caso normalmente é a do autor ou do narrador) capaz de se sobrepor a todas as outras vozes que dialogam na obra.

Por conseguinte, o romance polifônico só se torna possível quando há da parte do autor da obra uma nova posição em relação ao herói representado. A maneira que Dostoiévski criou para evitar as definições redutoras foi o enfoque dialógico da personagem, através do qual ela se revela na resposta às palavras dos outros sobre si, ou mesmo em um intenso diálogo consigo mesma. Assim, nas palavras de Bakhtin, "a nova posição artística do autor em relação ao herói no romance polifônico de Dostoiévski é uma posição dialógica seriamente aplicada e concretizada até o fim, que afirma a autonomia, a liberdade interna, a falta de acabamento e definição do herói. (...) E esse diálogo - o 'grande diálogo' do romance na sua totalidade - realiza-se não no passado,

\footnotetext{
${ }^{40}$ BAKHTIN, Mikhail, Problemas da Poética de Dostoiévski, tradução direta do russo, notas e posfácio de Paulo Bezerra. Rio de Janeiro: Forense Universitária, 2010, 5. Ed, p. 5, 6.

${ }^{41}$ Idem, p. 5, 6.
} 
mas neste momento, ou seja, no presente do processo artístico. (...) Em Dostoiévski, esse grande diálogo é artisticamente organizado como o todo não fechado da própria vida situada no limiar",42.

Bakhtin defende a tese segundo a qual as personagens das obras de Dostoiévski não são reveladas ou caracterizadas por elementos externos a elas (características físicas, posição social etc.), mas sim pela percepção que elas têm de todos esses fatores objetivos e, em última instância, pela consciência que elas possuem delas próprias. $\mathrm{O}$ que Dostoiévski revela ao leitor é o que a personagem tem a dizer sobre si próprio e não o que ela "é", exatamente porque não há espaço para tipos sociais ou heróis de imagem acabada. Por conseguinte, nas obras de Dostoiévski se evidencia que o homem não pode ser transformado "em objeto mudo de um conhecimento à revelia. No homem sempre há algo, algo que só ele mesmo pode descobrir no ato livre da autoconsciência e do discurso, algo que não está sujeito a uma definição à revelia, exteriorizante" ${ }^{43}$.

Bakhtin sustenta que ao conceder ao herói a responsabilidade pela sua autodefinição, que antes cabia ao autor, Dostoiévski realizou uma espécie de pequena "revolução copernicana" na criação artística, sem trazer matéria essencialmente nova. O que era função do autor e do narrador passa para a personagem que define a si mesma e à realidade circundante a partir da sua autoconsciência. Ocorre uma transferência da matéria do romance do campo de visão do autor para o campo de visão da personagem.

Ao abster-se de definir o herói, de acabá-lo de forma redutora, Dostoiévski forjou uma nova visão sobre o homem. Através do romance polifônico o homem complexo, incoerente, imprevisível, conquistou espaço no âmbito da literatura. O escritor russo, dessa forma, antecipou um dos grandes desafios com o qual se deparará o

\footnotetext{
${ }^{42}$ Idem, p. 71, 72.

${ }^{43}$ Idem, p. 66.
} 
biógrafo do século XX: a percepção de que a personalidade humana não se revela de forma simples e imediata aos olhos de outrem (e menos ainda do biógrafo), e que, por conseguinte, as definições exteriores que uma pessoa faz de outra são sempre desprovidas de profundidade. Além disso, o romancista russo conseguiu elaborar em seus romances personagens tão alheios aos seus destinos, tão perplexos diante dos entroncamentos e das vicissitudes do porvir que se parecem muito mais com os homens reais que nada sabem sobre o dia de amanhã do que com tudo o que foi criado anteriormente na tradição literária ocidental. É essa experiência artística “como o todo não fechado da própria vida situada no limiar" que os biógrafos tentarão reportar em suas biografias dedicadas a homens que, enquanto vivos, experimentaram existências tão errantes e abertas quanto às de todos nós.

Assim, em virtude dessa transformação que se evidencia na literatura do século XIX, principalmente a partir das obras de Dostoiévski e que se aprofunda no século XX, "ligada ao advento de novos paradigmas em todos os campos científicos: crise da concepção mecanicista da física, surgimento da psicanálise, novas tendências da literatura (basta citar os nomes de Proust, Joyce e Musil)"44, o sentimento de complexidade da personalidade humana passa a dominar as concepções correntes acerca do homem. As biografias começam a se ater a essa grande complexidade e os leitores se voltam para elas em busca de seres tão fragmentados e partidos quanto eles próprios, portanto seres reais. Nas palavras de Nicolson, citadas por Maurois, "La biographie est une préoccupation, une consolation, non de la certitude, mais du doute" ${ }^{\text {. }}$.

Uma nova tarefa, reconhecidamente delicada, é assumida pelo autor de biografias: a responsabilidade de enumerar os incontáveis aspectos de uma vida. Dessa

\footnotetext{
${ }^{44}$ LEVI, Giovanni "Usos da biografia" in. FERREIRA, Marieta de Moraes e AMADO, Janaina (orgs) Op. Cit., p. 172, 173.

${ }^{45}$ MAUROIS, Op. Cit., p. 39.
} 
maneira, os biógrafos começam uma busca (algumas vezes infrutífera), pelos inúmeros traços que compõem a personalidade do biografado. Essa busca agrava a sensação de inconclusividade do trabalho do biógrafo, que se depara a todo instante com infinitas fontes e facetas do seu biografado, e o caráter ilusório inescapável do trabalho final, pois nas palavras de François Dosse "sem dúvida, a ânsia de dar sentido, de refletir a heterogeneidade e a contingência de uma vida para criar uma unidade significativa e coerente traz em si boa dose de engodo e ilusão" 46 .

É por essa razão que os biógrafos atualizados com os debates e discussões referentes ao gênero biográfico têm evitado essa "ânsia" de dar sentido a uma trajetória humana. Trata-se de uma importante mudança de rota, pois o gênero biográfico começa a se afastar de uma das suas características constitutivas: a crença de que as vidas dos indivíduos encerram um sentido, uma verdade intrínseca revelada por meio de uma cronologia ordenada, orientada pela ideia de progresso. A vida pode ser contada como uma história? Pode ser narrada como uma totalidade, uma unidade provida de sentido?

"Écrire La vie d'um homme, c'est pretendre a une forme de totalité" 47 , decretou Phillipe Lejéune. E, dentre todos os autores que questionaram a ambição à totalidade do gênero biográfico o mais célebre é Pierre Bourdieu, que também identificou a responsabilidade do biógrafo na atribuição de sentido à vida que busca reconstituir. $\mathrm{Na}$ visão do autor, estabelece-se uma relação de cumplicidade entre biógrafo e biografado, visando a uma criação artificial de sentido. É por essa razão que a biografia não pode ser lida senão como uma ilusão deliberadamente forjada pelo biógrafo $-a$ ilusão biográfica. Para Bourdieu, a crença que se oculta sob esse "postulado do sentido da

\footnotetext{
${ }^{46}$ DOSSE, Op. Cit., p 12.

${ }^{47}$ LEJEUNE, Philippe Je Est un Autre: L'Autobiographie de la Littérature aux Médias. Paris: Seuil,1975, p.78.
} 
existência narrada" é a de que a vida de um sujeito é um fluxo retilíneo em direção a um fim determinado, que desde a primeira infância faz-se perceptível a partir da observação das características desse sujeito. É por isso que as biografias são recheadas de frases como, por exemplo, “desde pequeno ele gostava de música”, quando a biografia em questão é a de um músico famoso, ou nos recorrentes "já”, "sempre”, “desde então", entre outros, que se tornaram lugares-comuns do gênero biográfico. $\mathrm{O}$ desenvolvimento da tese sustentada por Bourdieu se dá no decorrer do texto a partir da recusa da pertinência do nome próprio, que traria consigo a falsa ideia de que o sujeito é tão coerente quanto a sucessão de acontecimentos da sua vida narrados na sua biografia.Ao rejeitar a coesão do sujeito e de uma existência individual, Bourdieu responde de forma negativa à questão: a vida é uma história? Diferentemente do que pensa o senso comum, que concebe a vida como um "caminho" com começo, meio e fim (este último é também entendido como finalidade). Isso, na visão de Bourdieu, é "aceitar tacitamente a filosofia da História”, teoria esta que pressupõe que:

(...) 1- a vida constitui um todo, um conjunto coerente e orientado, que pode e deve ser apreendido como expressão unitária de uma intenção subjetiva e objetiva, de um projeto"; 2"essa vida organizada como história transcorre, segundo uma ordem cronológica que é também uma ordem lógica, desde um começo, uma origem, no duplo sentido de ponto de partida, de início, mas também de princípio, de razão de ser, de causa primeira, até seu término, que também é um objetivo"; 3- "o relato (...) propõe acontecimentos que, sem terem se desenrolado sempre em sua estrita sucessão cronológica (...) tendem ou pretendem organizar-se em sequências ordenadas segundo 
relações inteligíveis. $\mathrm{O}$ sujeito e o objeto da biografia (o investigador e o investigado) têm de certa forma o mesmo interesse em aceitar o postulado do sentido da existência narrada (e, implicitamente, de qualquer existência) ${ }^{48}$

É essa teoria da filosofia da História contrabandeada para a vida de um indivíduo que Bourdieu ajuda a deitar por terra com este artigo que é hoje um clássico da bibliografia referente ao gênero biográfico.

Diante de um ataque contumaz como o de Bourdieu, é notório observar que as dúvidas acerca da possibilidade da biografia são inúmeras e até hoje não foram satisfatoriamente solucionadas. No entanto, mesmo com todos os problemas formulados e debatidos ao longo da História acerca da sua pertinência, é surpreendente que o gênero biográfico figure entre os mais praticados e queridos do público leitor. Depois de textos e mais textos, manifestos e mais manifestos (como o do próprio Bourdieu) contra o sentido de se continuar a escrever biografias, estas se multiplicam nas estantes das livrarias e conquistam cada vez mais espaço no universo acadêmico e de pesquisa.

É forçoso indagar a que se deve a vitória da biografia. Uma resposta possível é o fato de muitos biógrafos terem convertido as fragilidades epistemológicas no mote da atual empreitada biográfica. Como afirmou Giovanni Levi, “a própria complexidade da identidade, sua formação progressiva e não linear e suas contradições se tornaram os protagonistas dos problemas biográficos"49. Dessa forma, ainda segundo o autor, nos últimos anos os historiadores/biógrafos "passaram recentemente a abordar o problema biográfico de maneiras bastante diversas" ${ }^{\circ 0}$. Dentre essas maneiras diversas Levi chama

\footnotetext{
${ }^{48}$ BOURDIEU, Pierre "A ilusão biográfica" IN: FERREIRA, Marieta de Moraes e AMADO, Janaina (orgs) Op. Cit., p. 184.

${ }^{49}$ LEVI, Giovanni "Usos da biografia" IN: FERREIRA, Marieta de Moraes e AMADO, Janaina (orgs) Op. Cit., p. 173.

${ }^{50}$ Idem, p. 174.
} 
a atenção para algumas delas como, por exemplo, a Prosopografia e biografia modal, que são biografias que se debruçam sobre uma trajetória individual, mas somente na medida em que esta trajetória sintetiza as características do seu grupo social; ou a Biografia e contexto, quando o meio, a época, ou seja, o contexto histórico e social aparece como uma forma de tornar inteligíveis as trajetórias individuais; ou ainda a Biografia e hermenêutica, perspectiva na qual o material biográfico torna-se essencialmente discursivo, entre outras.

De qualquer maneira, independentemente da tipologia na qual se encaixam as biografias que emergem da reflexão que acompanha o desenvolvimento do gênero, estas oferecem com frequência soluções ousadas e interessantes para os desafios biográficos. E as expectativas com relação aos resultados das biografias se pautam majoritariamente pela maneira como o biógrafo incorpora ao texto a dimensão inescapável da nossa humanidade, que segundo Leon Edel é a certeza de que "we are self-contradicting and ambivalent, that life is neither as consistent nor as intellectual as biography would have it be". Assim, ainda segundo o biógrafo de Henry James, "when we come as close as possible to character and personality and to the nature of temperament and genius, we have written the kind of biography that come closes to "truth",51, sendo que a verdade ("truth") biográfica "is not and can never be absolute truth", ${ }^{\text {, }}$ mas sim verossimilhança. À guisa de conclusão, é inevitável terminar o percurso pelos caminhos e descaminhos do gênero biográfico com uma sensação de inconformidade com a injustiça que historicamente se abateu sobre os biógrafos, que por muito tempo foram desprezados como simples polígrafos desocupados, dedicados por capricho a um gênero literário simples e banal. Diante da constatação da complexidade da empreitada biográfica, o

\footnotetext{
${ }^{51}$ EDEL, Op. Cit., p. 108.

${ }^{52}$ KENDALL, Op. Cit., p. 130.
} 
biógrafo assume o papel do destemido autor de um dos gêneros literários mais fascinantes e desafiadores. "My God, how does one write a biography?",53, indagou Virgínia Woolf, ela mesma responsável por três memoráveis incursões ao gênero biográfico. As incontáveis biografias escritas sobre a vida de Fiódor Dostoiévski nos fornecem uma amostra objetiva de como a biografia, apesar de todas as suas contradições intrínsecas, permanece uma aventura intelectual atraente e recorrentemente (irresistivelmente?) revisitada. Principalmente quando a vida em questão, como ocorre com a trajetória do romancista russo, é recheada de saborosas anedotas e de episódios dignos da mais criativa ficção. A tradição biográfica que surgiu a partir da narração da vida do grande escritor russo, por sua vez, convive com uma faceta importante do biografado, que é a autoria de uma obra literária cujas inovações artísticas (a polifonia e a solução dialógica) desestabilizaram as pilastras que durante muito tempo ergueram a razão de ser do gênero biográfico. É forçoso procurar descobrir como os biógrafos de Dostoiévski se saíram nesta notória “ousadia” biográfica.

${ }^{53}$ NADEL, Op. Cit., p. 31. 


\section{Fiódor Dostoiévski: uma vida "hiperbiografável"}

Pode uma vida humana proporcionar-nos o prazer de uma obra de arte? Ou, como preferiu Henry Troyat na advertência da sua biografia Dostö̈evsky - "Combien d'hommes ilustres ont dês vies qui ne sont pas à la taille de leurs oeuvres!"54. Dostoiévski é um desses homens raros, cuja história de vida poderia confundir-se com o enredo de um dos seus grandes romances. Não é por acaso que o escritor se tornou uma figura "hiperbiografável".

É compreensível que uma trajetória marcada por eventos trágicos como o brutal assassinato do pai, enfermidades como a epilepsia, episódios macabros como a condenação à pena de morte comutada para a prestação de trabalhos forçados na Sibéria, dificuldades afetivas, financeiras etc. forneça vasto material para qualquer biógrafo atento. É irônico, entretanto, que o personagem de incontáveis biografias seja o mesmo homem que com sua obra contribuiu para a crise definitiva do gênero biográfico ao escancarar as complexidades que envolvem a personalidade humana e a tarefa vã e sempre inconclusiva de definir alguém à sua própria revelia.

De qualquer forma, a atração que a vida atribulada de Dostoiévski exerce sobre os seus admiradores não é a única razão para a propagação das biografias. A ânsia por compreender os romances também explica a tentativa de reconstituição da trajetória de vida do escritor russo. O importante biógrafo Konstantin Mochulsky, por exemplo, acredita que a imersão na biografia de Dostoiévski é uma chave poderosa para o entendimento do sentido da sua obra. Na visão de Mochulsky, não existe uma separação

\footnotetext{
${ }^{54}$ TROYAT, Henry, Dostoïevsky. Rio de Janeiro: Americ=Edit, 1940, p. 9.
} 
entre o ofício de Dostoiévski e a maneira como ele viveu, portanto "the closer we approach the man, the more intelligible the writer then becomes to us"

Dostoevsky - His Life and Work, publicada na década de 1940, ocupa até hoje lugar de destaque entre as mais importantes obras do gênero já escritas sobre a vida de Dostoiévski. Não é por acaso que a biografia literária da autoria de Mochulsky é uma das principais referências bibliográficas de Joseph Frank. Membro do numeroso grupo dos intelectuais russos emigrados, Mochulsky deixou a Rússia em 1919 e lecionou na Universidade de Sofia e na Universidade de Sorbonne, em Paris, cidade na qual se estabeleceu e onde publicou a obra sobre a vida de Dostoiévski. Um dado interessante da biografia de Mochulsky é que no final dos anos 1920 e início dos anos 1930 ele vivenciou uma aguda crise espiritual seguida por fervorosa conversão religiosa. Começou a frequentar as reuniões da “Berdyayev’s Religio-Philosophical Academy” e a contemplar o monasticismo, chegando a se desfazer de todos os seus livros e bens materiais. A fase religiosa da vida de Mochulsky foi coroada pelo encontro com "mother Mariya", uma freira russa muito popular entre os russos emigrados místicos que viviam em Paris na época.

Esse dado é uma ferramenta interessante para buscar as motivações de Mochulsky diante da tarefa de escrever uma obra sobre Dostoiévski. Na visão do biógrafo "[Dostoevsky] lived in literature", pois "in all of his works he resolves the enigma of his personality" ${ }^{, 56}$, sendo que este enigma relaciona-se à religiosidade de Dostoiévski e à maneira como o escritor transformou o conflito interior que o atormentou durante toda a vida no mote da sua produção artística literária.

\footnotetext{
55 MOCHULSKY, Konstantin. Dostoevsky, His Life and Work. Translated, with an introduction, by Michael A. Minihan. Princeton University Press, 1967, p. 535.

${ }^{56}$ Idem, p. XIX.
} 
A crise que acometeu o cristianismo no século XIX ecoou em Dostoiévski como uma tragédia individual, e a dúvida entre a crença e a descrença ocupou o centro dos grandes romances do escritor russo. Mochulsky escreveu: "this man who was responsible for the most brilliant argumentation ever written in defense of atheism, this man whom 'throughout [his] entire life God tormented' combined within his heart the most ardent faith with the greatest disbelief. All the religious dialectic of his novels stems from this tragic duality"

$\mathrm{Na}$ biografia, porém, as aproximações entre vida e obra não se restringem à representação literária que Dostoiévski realizou do seu grave conflito interior. Na opinião de Mochulsky, em muitas das personagens dos romances encontram-se traços e características do próprio Dostoiévski. É o caso, por exemplo, do romance inacabado Niétotchka Nezvânova, que foi escrito no começo da carreira do romancista russo, mais especificamente um pouco antes da prisão e do exílio para a Sibéria, quando a opinião dos círculos literários de São Petersburgo era a de que ele não passava de um escritor de uma obra só (Pobre Gente), cuja produção que sucedeu a este grande sucesso consistia em uma coleção de exemplos de má literatura. Para Mochulsky, Dostoiévski emprestou ao personagem Iefimov, o violinista fracassado e padastro de Niétotchka, a insegurança que ele sentia acerca do valor do seu talento enquanto escritor. Segundo Mochulsky "Yefmov was born out of the painful sufferings of the artist's imagination, from the plaguing idea that his talent of itself had been consumed"

Outros exemplos desta aproximação entre vida e obra são facilmente identificáveis na biografia. É o caso do romance $O$ Idiota, que já foi apontado por muitos biógrafos, inclusive Joseph Frank, como o mais pessoal do escritor, no qual ele

\footnotetext{
${ }^{57}$ Idem, p. 120.

${ }^{58}$ Idem, p. 113.
} 
expressou as suas mais íntimas convicções. Na visão de Mochulsky, o príncipe Míchkin é o autorretrato artístico de Dostoiévski e a história da personagem é a biografia espiritual do seu criador. Assim, "Dostoevsky's novels are the history of his soul; the interior is projected in the exterior, in myths and symbols (the characters, plots, composition). His personal consciousness is revealed in its universality" ${ }^{, 59}$.

Portanto, é legítimo afirmar que a aproximação entre vida e obra que configura o método da biografia é resultado da interpretação de Mochulsky que considera a obra de Dostoiévski uma unidade. Este pressuposto se evidência na maneira como o biógrafo analisa a produção literária do escritor: através da composição da gênese do romance, portanto de uma interpretação que defende que todos os romances que Dostoiévski escreveu consistem essencialmente em um único grande romance, cuja temática é a revelação da personalidade e do conflito interior do seu autor. Dessa forma, na visão de Mochulsky existe uma ideia-força, uma mensagem que norteia a produção artística do romancista russo como um todo, sendo que essa ideia-força já se encontrava presente nas obras de juventude e foi se aprimorando até culminar em Irmãos Karamázov, "from which we see the organic unity of the writer's whole creative work disclosed"60 e que, por conseguinte, “is not only a synthesis of Dostoevsky's creative work, but also the culmination of his life",61.

Assim, a gênese do romance empresta um sentido de revelação à produção artística de Dostoiévski; a filosofia religiosa que foi ganhando espaço e centralidade na vida do escritor, apesar de sempre ter estado presente como uma primitiva intuição é, na visão de Mochulsky, o teor dessa profunda revelação. Por conseguinte, a conexão orgânica entre vida e obra amplifica o efeito sintético da biografia, pois ilustra como

\footnotetext{
${ }^{59}$ Idem, p. 369.

${ }^{60}$ Idem, p. 596.

${ }^{61}$ Idem, p. 597.
} 
essas duas esferas se interpenetraram determinantemente. A biografia escrita por Mochulsky também reluz como um todo orgânico aos olhos do leitor, pois à maneira como ele interpreta a obra do escritor nos termos da sua intuição primária e analisa a mesma a partir da sua síntese natural de forma e conteúdo soma-se à admiração e idealização - corroborada pela condição de emigrado em crise religiosa - que ele nutre pelo seu biografado. O resultado é uma obra que ganha em beleza poética, mas perde em objetividade e imparcialidade, porém sem deixar de ser uma grande contribuição para a produção crítica existente sobre Dostoiévski.

A aproximação entre vida e obra nem sempre é fruto de um método baseado em uma leitura específica de uma obra literária, como é o caso da biografia de Mochulsky, mas é uma ideia muito arraigada no senso comum, que acredita que a personalidade do escritor pode ser decifrada por meio das suas obras. Esse movimento de buscar o autor nos seus livros funciona como um atalho para o biógrafo que se debruça sobre a vida do seu objeto sem realizar o trabalho de pesquisa nas fontes primárias e secundárias. Isto ocorre, por exemplo, em uma obra sobre Dostoiévski da autoria de um escritor brasileiro publicada no país na década de 1980. Intitulada Dostoiévski, um cristão torturado, a biografia foi escrita por Virginio Santa Rosa, engenheiro civil de formação, político $^{62}$ e escritor em diversas frentes ${ }^{63}$.

A biografia da autoria de Santa Rosa se divide em três partes: "O Homem”, "O Romancista" e "O Visionário". Na primeira parte, a mais extensa, Santa Rosa realiza o trabalho do biógrafo, apesar da narração biográfica não estar de todo ausente nas outras duas partes do livro, destinadas à análise da obra e do significado da produção literária

\footnotetext{
${ }^{62}$ Foi deputado federal pelo estado do Pará de 1950-60 e secretário-geral do Partido Social Progressista de 1954 a 1962.

${ }^{63}$ Escreveu obras de História ( $O$ sentido do tenentismo), relatos de viagens (Paisagens do Brasil), ensaios de análise sociológica ( $O$ século da violência), romances ( $A$ estrada e o rio), além da obra biográfica sobre a vida do célebre romancista russo.
} 
de Dostoiévski. Isso porque a biografia assinada por Santa Rosa é concebida segundo as biografias literárias clássicas, e nela divisa-se o pressuposto teórico já mencionado que o sentido da obra pode ser apreendido das passagens da vida do escritor.

Nas primeiras páginas de Dostoievski, um cristão torturado, deparamo-nos com a ideia de que Dostoiévski já nasceu escritor (ou assim era antes mesmo de nascer), como é possível se inferir na passagem "Maria Federovna(...) carregava também no ventre a criança que tornaria o seu nome para sempre lembrado" "64. A opção de Rosa por retratar a trajetória de Dostoiévski como se desde o nascimento o talento do escritor já estivesse presente é reforçada pela ideia de predestinação, ou a concepção do talento como uma dádiva divina: “(...) a Divina Providência derramou no berço de Fédor essas dádivas magníficas: a fábula e a realidade. Não podia existir melhor presente para o futuro romancista"65. Ou, como consta em outra passagem: "Escrever era o seu destino"

Na biografia em questão, há pouco espaço para o imprevisível, para o aleatório, para o misterioso da vida. E a convicção de que essa vida se desenrola de maneira necessária e retilínea encontra eco no posicionamento do biógrafo diante da sua narração biográfica, que em poucas passagens atina para a possibilidade de que as coisas poderiam ter se passado na vida de Dostoiévski de maneira distinta daquela narrada. Apenas no início da biografia Rosa evita afirmações categóricas, valendo-se de atenuantes como "Talvez, em suas meditações de hipocondríaco", ou "decerto o demônio da avareza devia..." ${ }^{67}$. Também quando lança hipóteses muito ousadas Rosa tem o cuidado de relativizar o alcance dos seus voos detetivescos, como na passagem

\footnotetext{
${ }^{64}$ ROSA, Virginio Santa, Dostoievski, um cristão torturado. Rio de Janeiro: Editora Civilização Brasileira, 1980, p. 13.

${ }^{65}$ Idem, p. 14.

${ }^{66}$ Idem, p. 45.

${ }^{67}$ Idem, p. 12, 13.
} 
em que afirma a partir da identificação de confissões autobiográficas de Dostoiévski na obra Niétotchka Niezvânova que Dostoiévski teria descoberto a infidelidade da mãe ao encontrar uma carta esquecida em um livro, e isso explicaria o porquê do escritor russo nunca ter falado nela, não ter lamentado a sua morte nem ter exaltado figuras maternas em sua obra.

Hipóteses como estas, baseadas em uma correspondência necessária entre a vida do escritor e as suas obras, são recorrentes na biografia. Por exemplo, Rosa sugere que no auge da sua pobreza Dostoiévski deve ter desejado a morte do usurário que o emprestou dinheiro a juros (supondo que ele tenha feito algum empréstimo); ou que durante os seus meses errantes na Europa, onde vivera como um miserável, ele teria repetido “(...) na própria pele, a experiência do seu herói, o homem do subterrâneo”68, até o dia em que desmaiou em um banco de praça e despertou com a ideia de Crime e Castigo; ou na afirmação que todos os personagens de $O$ Idiota foram inspirados em pessoas reais, que Dostoiévski conheceu ao longo da sua vida. Ou, por fim, no trecho no qual se refere ao romance $O$ Jogador: "desprendendo-se das dores já vividas, Dostoievski contempla e retoca esse período de sua vida como espectador distante e indiferente. Mesmo o inferno do jogo, motivo central do romance, perde por vezes um pouco da sua fatalidade baixeza" ${ }^{\prime 69}$.

Dessa maneira, concluímos que algumas das principais fontes do biógrafo são as obras do biografado. As demais fontes nos são praticamente desconhecidas, pois Santa Rosa não se preocupa em mencioná-las até o final da biografia - é somente no XIX ${ }^{\circ}$ capítulo, na página 300 do livro, que aparece uma referência explícita às fontes utilizadas, sendo a principal delas o diário de Ana, a segunda esposa de Dostoiévski.

\footnotetext{
${ }^{68}$ Idem, p. 198.

${ }^{69}$ Idem, p. 219.
} 
Apesar do desconhecimento das fontes do biógrafo é possível supor que Santa Rosa leu algumas biografias clássicas sobre Dostoiévski, pois muitas das suas afirmações repetem o que durante muito tempo se difundiu em uníssono sobre a vida do romancista russo. Por exemplo, a suposta infância triste sob a égide do pai carrasco é descrita com tintas muito vivas na biografia. Na visão do biógrafo, o pai de Dostoiévski era terrível e a vida em família "insuportável”"70 e por essa razão a infância do escritor fora vivida em clima propício para a manifestação de doença mental. Citando o clássico estudo de Freud, Dostoiévski e o parricídio, Santa Rosa defende que o escritor inconscientemente desejava a morte do pai e após o assassinato deste último pelos servos da propriedade rural da família Dostoiévski, o romancista desenvolveu a epilepsia que o acompanhou até o final da vida. O biógrafo afirma ainda que esse acontecimento fora de suma importância para a obra futura de Dostoiévski, tendo inspirado diretamente o parricídio de Os Irmãos Karamázov.

É importante ressaltar, entretanto, que apesar dos traços “convencionais" dessa biografia, o que a torna um tanto enfadonha para os leitores dos nossos dias familiarizados com as novas soluções que o gênero biográfico tem tentado encontrar para fazer frente aos seus críticos, ainda assim Dostoievski, um cristão torturado tem aspectos dignos de interesse. Dentre esses aspectos se destaca a "imparcialidade" do biógrafo frente à figura grandiosa de Dostoiévski. Se por um lado o biógrafo exalta o escritor e não economiza elogios à sua obra, por outro lado ele não silencia diante do que considera "uma vaidade mórbida [que] revela, antes de tudo, desequilíbrio, tendências neuróticas" ${ }^{\text {,11 }}$, ou seja, um temperamento difícil.

\footnotetext{
${ }^{70}$ Idem, p. 18.

${ }^{71}$ Idem, p. 57.
} 
Dessa maneira, em diversos momentos do livro Santa Rosa chama atenção para os sinais de desequilíbrio psíquico manifestados por Dostoiévski e não o isenta da responsabilidade pelas dificuldades enfrentadas por ele em vida. No que diz respeito à sua juventude, Rosa entende que os retumbantes fracassos literários que Dostoiévski colecionou após o sucesso de Gente Pobre e o tormento no qual se transformou a sua vida são de sua exclusiva responsabilidade, assim como não relativiza o vício pelo jogo do escritor, o que transformou seu dia a dia com Ana na Europa em um verdadeiro pesadelo. Quanto à obsessão do escritor pela roleta, o biógrafo não mede palavras: “(...) Junto da roleta, ele perdia a serenidade e, não dominando seus nervos, arriscava até a última ficha. O que ganha em uma parada, perde em outra. E persiste jogando como um alucinado, enquanto the resta dinheiro ou pode obtê-lo de qualquer modo. Gasta tudo o que possui, empenha a roupa do corpo, comete indignidades sem nome para arranjar com que adquirir mais uma ficha" ${ }^{, 2}$.

Rosa também desaprova a mania de Dostoiévski de importunar os amigos e principalmente seu irmão mais velho com pedidos e súplicas invariavelmente referentes a socorros financeiros. Na visão do biógrafo, Dostoiévski "Lamenta-se sem cessar. Contudo, assim que arranja qualquer quantia, gasta sem freio e medida. E quando não tem nada, vive na mais completa miséria, recorre a todo mundo, endivida-se sem temor das consequências... Depois, desfia o rosário de queixas e imprecações, culpando Deus e o Diabo. Só não refreia é o seu orgulho, sua vaidade sem limites"73.

Apesar de salientar o desequilíbrio psíquico de Dostoiévski, Rosa se recusa a tratá-lo como um louco como muitos dos contemporâneos do escritor o consideraram. O tema da loucura é discutido por meio do famoso Retrato de Dostoiévski, de Perov, que

\footnotetext{
${ }^{72}$ Idem, p. 260.

${ }^{73}$ Idem, p. 67.
} 
impressionou toda a Rússia quando exposto na Academia de Belas Artes. Segundo o biógrafo, a força e o realismo do retrato que expõe um homem em atitude meditativa, introspectiva e um tanto quanto enigmática convenceu os contemporâneos de que se tratava do retrato de um louco. Para Rosa, "Nada disso. Era apenas, tão somente, o retrato de um epiléptico"74. Esse mesmo tema vem à tona quando o biógrafo comenta $\mathrm{o}$ lançamento de Os demônios, quando as acusações mais disparatadas foram dirigidas ao seu autor. Novamente Dostoiévski foi chamado de "reacionário, de débil mental, de louco"75. O biógrafo, por sua vez, rejeita todos esses rótulos e prefere enxergar o romancista como um homem incompreendido, uma inteligência superior às voltas com as suas questões existenciais e as cisões da sua personalidade.

Outro aspecto desse livro que torna a sua leitura prazerosa é a narrativa romanceada da qual se vale o seu autor. Sabemos que essa solução é sempre uma via de mão dupla: se por um lado ela confere uma maior fluidez ao texto biográfico e dissimula lacunas incontornáveis na documentação, por outro lado ela transforma o texto em um discurso infinitamente menos crível sobre a verossimilhança da vida de alguém. No livro de Rosa a opção pelas técnicas oriundas do campo da ficção torna a leitura palatável, mas suscita a desconfiança do leitor, principalmente quando este se depara com diálogos no corpo da narrativa biográfica. Como por exemplo, no trecho no qual o biógrafo descreve o desencontro amoroso de Dostoiévski com Apolinária Súslova na Europa:

Na hora aprazada, ela o recebe, muito pálida, de olhos secos.

- Pensei que não viesse mais. Não recebeste a minha carta?

- Que carta?

- Aquela onde te dizia que não viesses.

- Por quê?

- Porque é tarde demais.

\footnotetext{
${ }^{74}$ Idem, p. 303.

${ }^{75}$ Idem, p. 307.
} 
Ele baixou a cabeça para esconder a emoção. Paulina - que conta a cena - não lhe vê a face torturada. Só enxerga os fios do seu cabelo cor de aço.

- Escuta, Paulina - disse-lhe com a voz enrouquecida. - Preciso saber de tudo. Vamos aonde quiseres. Tu vais dizer-me tudo, senão morrerei $^{76}$.

Muitas outras passagens como esta podem ser retiradas das páginas dessa biografia. A utilização das técnicas da literatura também é muito evidente quando o biógrafo narra a participação de Dostoiévski no círculo Petrachévski, criando certo clima de suspense, ou ainda quando o ele se debruça sobre a paixão do escritor por Maria Dmitrievna, sua primeira esposa, e compõe quase um romance sentimental a partir dos dados biográficos dos quais dispõe.

É oportuno atentar para o fato que o resultado obtido por Santa Rosa em Dostoievski, um cristão torturado é diametralmente oposto ao resultado obtido pelo historiador britânico Edward Carr na sua obra Dostoevsky, também uma biografia. O flerte com a literatura que identificamos na obra do autor brasileiro está de todo ausente na biografia do historiador britânico e, enquanto Rosa elabora um texto atraente próximo da ficção, Edward Carr, comprometido com a exatidão dos fatos narrados, não se arrisca para além do limite imbricado no alcance das fontes documentais. Assim, nos deparamos com duas obras biográficas que, apesar de narrarem a vida do mesmo homem, apresentam mais diferenças do que semelhanças, sendo que as diferenças se devem antes às posturas assumidas pelos biógrafos do que a eventuais discrepâncias entre os fatos narrados em uma e outra obra. Santa Rosa biografa a vida de um autor que admira, principalmente em função da mensagem cristã que ele identifica na obra de Dostoiévski, e que elege como um grande "exemplo de homem"77. Já Carr descreve a si

\footnotetext{
${ }^{76}$ Idem, p. 184.

${ }^{77}$ Idem, p. 344.
} 
próprio como o "objective biographer" ${ }^{\text {, }}$, que olha para a vida de Dostoiévski com o olhar do historiador, distanciado e objetivo, que procura não se deixar levar por opiniões pessoais e sentimentos e almeja narrar os fatos exatamente como eles se passaram.

A biografia Dostoevsky foi publicada na década de 1930 e é o trabalho de estreia de Edward Carr $^{79}$. Ao contrário de Santa Rosa, percebemos a preocupação de Carr com a pertinência da documentação consultada, pois já na introdução da obra o autor participa ao leitor quais fontes foram utilizadas na construção do texto e quais outras obras biográficas lhe serviram de parâmetro. Ele também adverte que é improvável que existam documentos desconhecidos sobre a vida do escritor, e duvida que uma nova luz possa ser lançada sobre essa vida a partir de uma hipotética descoberta de novidades documentais.

Ainda no que diz respeito à documentação histórica, Carr evita ao máximo recorrer às obras ficcionais de Dostoiévski em busca de pistas sobre a vida do escritor ${ }^{80}$. É interessante notar que Carr examina com enorme desconfiança as fontes deixadas pelo próprio Dostoiévski, em uma atitude familiar aos historiadores mais sérios, que sempre suspeitam das suas fontes. No momento em que analisa a justificativa de Dostoiévski para o rompimento com Bielínski e seu círculo, Carr não mede as palavras ao afirmar que "It is a striking instance of the unconscious dishonesty which makes highly imaginative people like Dostoevsky the most unreliable of witnesses to the facts of their own life" ${ }^{\prime 81}$.

\footnotetext{
${ }^{78}$ CARR, Edward Hallett. Dostoevsky 1821-1881. London: Unwin Books, 1962, p. 38.

${ }^{79} \mathrm{O}$ historiador britânico Edward H. Carr se notabilizou com a obra $O$ Que É História, hoje clássica no campo da historiografia.

${ }^{80}$ É apenas diante da novela $O$ Jogador que o historiador inglês repete o que se tornou quase um consenso da crítica e considera essa obra uma ficção com lampejos autobiográficos, na qual Dostoiévski examina o seu vício pelo jogo e descreve a sua paixão por Súslova.

${ }^{81}$ CARR, Op. Cit., p. 25.
} 
Percebemos na biografia de autoria de Carr, assim como na biografia de Rosa, uma postura crítica e nada complacente com as facetas pouco louváveis da personalidade de Dostoiévski. É digno de nota, por sua vez, que essa independência é tão pronunciada que a impressão que acomete o leitor de Dostoevsky é a de que para além da imparcialidade, ele está diante de uma velada desaprovação do biógrafo ao modo como o escritor russo conduziu a sua vida e atuou no seu tempo histórico.

A severidade de Carr pode ser explicada com base em uma breve análise do contexto da recepção de Dostoiévski na Inglaterra. A partir desse referencial, a postura do biógrafo diante do escritor russo reflete o seu posicionamento na polêmica que acompanha o surgimento da escola crítica dostoievskiana no país. Segundo René Wellek, autor do artigo “A Sketch of the History of Dostoevsky Criticism”, Dostoiévski foi descoberto tardiamente na Inglaterra em comparação com outros países da Europa como a Alemanha e a França. As primeiras traduções datam apenas das últimas décadas do século XIX e das primeiras décadas do século XX, sendo que os debates mais acalorados sobre o escritor surgiram somente após a eclosão da Primeira Guerra Mundial. A obra mais importante desse momento histórico é Fyodor Dostoevsky (1916), de Middleton Murry. Nas palavras de Wellek, o livro de Murry "extravagantly exalted Dostoevsky as the prophet of a new mystical dispensation" ${ }^{\wedge 2}$. O alcance das ideias defendidas por esse autor foi potencializado pela tradução na Inglaterra de textos de críticos russos como Berdiáev e Ivánov, que também empreenderam uma leitura centrada nas implicações filosóficas e teológicas da obra de Dostoiévski, e que por sua vez, corroboraram a aura de filósofo religioso e de profeta que envolveu a figura do escritor.

\footnotetext{
${ }^{82}$ WELLEK, René. Discriminations: Further Concepts of Criticism. New Haven and London, Yale University Press, 1970, p. 320.
} 
O período posterior à Primeira Guerra é marcado por uma forte reação a essa escola crítica. Nas palavras do autor, "English critical literature on Dostoevsky rather reflects a reaction of Murry and the Russians (Berdyaev and Ivanov) who were then translated into English. E H. Carr's biography (1931) may be characterized as excessively sober and detached" ${ }^{\prime 2}$. Assim, a biografia de Carr desponta como uma obra comprometida com o combate à leitura irracionalista e espiritualista do legado de Dostoiévski.

Além disso, é imperativo atentar para o fato que Carr é um intelectual marxista, afinado com a União Soviética. Não é por acaso que algumas posições de Dostoiévski como, por exemplo, o apoio ao Czarismo, assim como a crítica aos grupos revolucionários da sua época tenham calado fundo no intelectual marxista. $\mathrm{O}$ alinhamento com a URSS, por sua vez, comprometeu a aproximação do biógrafo a uma figura incômoda e controversa para os meios soviéticos.

Assim, é possível questionar a objetividade que Carr credita a si próprio. A postura de historiador sério e comprometido com as fontes históricas não é incompatível com resquícios de opiniões, posicionamentos políticos e sentimentos na tessitura do texto biográfico. No caso de Carr, os seus sentimentos são quase hostis, e o leitor chega a se perguntar por que razão teria o biógrafo se debruçado sobre a vida de Dostoiévski sem nutrir quase nenhuma simpatia por ele. Essa impressão assalta o leitor em trechos nos quais a fina ironia do biógrafo praticamente ridiculariza a figura de Dostoiévski. Isso ocorre quando Carr se detém ao indivíduo, mas também quando analisa o homem público, que anuncia as suas opiniões políticas e religiosas por meio da atividade jornalística nos interregnos das publicações dos romances.

\footnotetext{
${ }^{83}$ Idem, p. 322, 323.
} 
No que diz respeito ao homem Dostoiévski, por exemplo, logo no início da biografia Carr defende que o isolamento na infância incapacitou o escritor russo para o trato social, gerando uma necessidade excessiva por atenção - "the passionate need for exclusive devotion which clung to Dostoevsky through out life" ${ }^{\text {"4 }}$ - e a total inabilidade em relações amenas, descompromissadas e casuais. A todo o momento o biógrafo destaca o temperamento difícil e indisciplinado de Dostoiévski, a impressionabilidade, a incapacidade de adotar um estilo de vida regrado e razoável.

É por essa razão que o biógrafo se surpreende diante dos indícios de que o segundo casamento de Dostoiévski foi um grande sucesso e que ele se adaptou melhor do que ninguém a vida conjugal. É de forma bem-humorada que Carr afirma "the years of exile and isolation consummated the miracle - for such it seemed to him and it may sometimes seem to his biographer - of his married happiness" ${ }^{\wedge 5}$. Evidentemente que os méritos de tal proeza ele atribui muito mais a Ana do que ao próprio Dostoiévski, como ele mesmo afirma na frase: "but even when we have made the most generous allowance for Dostoevsky's virtues, we must still attribute to Anna rather than to him the brilliant success of their marriage" $" 86$.

Outro exemplo da rigidez do julgamento de Carr pode ser retirado do trecho no qual ele descreve o comportamento do escritor durante a sua primeira experiência de glória literária. É sabido que Gente Pobre foi imediatamente acolhida e festejada pelo círculo de Bielínski, e que o sucesso repentino despertou uma vaidade desmedida em Dostoiévski. A opinião do biógrafo sobre a postura do seu biografado neste período é bastante clara: "In short, Dostoevsky made a fool of himself" 87.

\footnotetext{
${ }^{84}$ Idem, p. 18.

${ }^{85}$ Idem, p. 137.

${ }^{86}$ Idem, p. 124.

${ }^{87}$ Idem, p. 24.
} 
As passagens duras como estas são inúmeras e também são encontradas nos excertos onde o biógrafo se refere às opiniões políticas de Dostoiévski. Nesse aspecto, é até legitimo afirmar que Carr praticamente não o leva a sério. A passagem de Dostoiévski do campo progressista para o campo conservador foi encarada quase como um dado necessário e lógico da trajetória do escritor. $\mathrm{Na}$ análise que empreende do momento progressista da juventude de Dostoiévski, na ocasião do rompimento com Bielínski, o biógrafo afirma que a versão que o escritor veiculou anos depois segundo a qual este teria ocorrido por divergências políticas e religiosas é falsa, pois o círculo ao qual ele se integrou posteriormente era tão progressista quanto o do célebre crítico russo e, como ocorre com qualquer jovem, as opiniões de Dostoiévski foram moldadas pelo seu entorno. Dessa forma, Carr sustenta que não há evidencias que comprovem que ele tenha feito grandes reflexões sobre as questões da sua época, e que nesse momento da vida ele não passava de um jovem imaturo e impressionável. Portanto, foi sem grande sobressaltos que se deu o que Carr definiu como "the evolution of the passionate young radical into na equally passionate, though scarcely more clear-headed, Champion of ortodoxy" $" 88$.

Carr também analisa de maneira pouco amistosa a produção jornalística de Dostoiévski. Nas publicações $O$ Tempo, A Época e principalmente no Diário de um Escritor o romancista russo defendeu algumas das suas polêmicas ideias, como a crença na missão histórica do povo russo de salvar a Europa da degradação e o apoio irrestrito ao Czarismo e à política externa imperialista do seu país. A aproximação ao conservadorismo político foi acompanhada da adesão à ortodoxia religiosa, e na visão do biógrafo o fervor religioso dos últimos anos de Dostoiévski pode ser explicado pelo

\footnotetext{
${ }^{88}$ Idem, p. 70.
} 
fato da religião não ter tido um papel importante nos primeiros quarenta anos da sua vida.

Dostoiévski não media esforços para conferir publicidade às suas ideias porque se via como um profeta depositário de uma missão moralizadora da maior importância. Nos seus últimos anos, vestiu com convicção o manto do profeta. O biógrafo não consegue disfarçar o riso ao afirmar que "His beliefs were not always consistent and seldom perfectly lucid, but he had a passionate unwavering faith in their immense importance for himself and for humanity" 89 . É por essa razão que, ainda segundo Carr, "It would have shocked him to be told that The Journal of an Artist would count for nothing with posterity beside The Idiot and The Brothers Karamazov"90. A conclusão das reflexões do biógrafo sobre a atividade de Dostoiévski como jornalista é, em poucas palavras: "Dostoevsky was a mediocre publicist and a supreme novelist"91.

Finalmente parece que atingimos uma das teses desenvolvidas em Dostoevsky capaz de responder satisfatoriamente à questão: por qual razão teria Edward Carr se dedicado à escrita da biografia de Dostoiévski? Esta se encontra sintetizada na afirmação de que Dostoiévski é o único romancista moderno do século XIX, uma vez que os contemporâneos Tolstói e Turguêniev pertencem ao mundo da aristocracia e da servidão, portanto ao passado. Dessa maneira, é legítimo concluir que é o romancista Dostoiévski que interessa ao historiador, e não o homem Dostoiévski, como no caso da biografia de Virginio Santa Rosa. E o rigor do método histórico utilizado conjuntamente à postura de biógrafo objetivo e imparcial libertou Carr para que ele compusesse um retrato de Dostoiévski da forma como ele acreditou ser a mais fidedigna possível aos fatos, sem a preocupação de forjar uma correspondência necessária entre a grandeza de

\footnotetext{
${ }^{89}$ Idem, p. 135.

${ }^{90}$ Idem, p. 213, 214.

${ }^{91}$ Idem, p. 235.
} 
uma vida e a grandeza de uma obra. Portanto, Carr demonstrou que é possível admirar um artista e ao mesmo tempo compor um retrato independente desse artista - no caso do biógrafo inglês, este demonstrou inclusive ser possível não nutrir grandes simpatias pelo homem que esse mesmo artista foi enquanto viveu.

Estamos inclinados a acreditar que Carr escreveu Dostoevsky por apreciar os romances do escritor russo, mais especificamente os romances da fase áurea inaugurada por Crime e Castigo e concluída com Os Irmãos Karamázov. Assim, para Carr, a correta apreciação do legado de Dostoiévski pressupõe a compreensão da centralidade da sua faceta de escritor, que necessariamente se sobrepõe às suas também talentosas facetas de psicólogo e filósofo. Foi como criador de personagens complexos, profundos, tão imprevisíveis e incoerentes como qualquer ser humano de carne e osso que o autor russo conquistou o seu lugar entre os grandes escritores da literatura universal. Esses personagens, que revelam a si nos momentos de crise existencial, representaram uma importante inovação literária, que na visão de Carr só encontra paralelo na obra de Shakespeare, de quem Dostoiévski figura como o herdeiro direto.

Dessa forma, ao equiparar o escritor russo com o mestre inglês, o biógrafo torna inteligível para o leitor o porquê da realização da biografia. Compreendemos então, através das palavras de Carr que figuram no epílogo da sua obra, a razão de ser de Dostoesvky:

And that is way, in seeking for parallels to Dostoevsky, the Englishman at any rate constantly returns to Shakespeare; for no subsequent English writer has conceived his characters in the same aspect, at once so profound and so incoherent, as the great Russian. Naked, inchoate human nature has vanished from English literature, and perhaps from English life, since the Elizabethan age. We have clothed and organized and confined ourselves in a multitude of traditions which have become part of our nature, and from which we can no longer escape even if we would; and it was only in a country so unorganized as Russia, 
and so untrammeled by rationalizing convention, that the nineteenth century could hope to recapture something of the starkness and the mobility of a more primitive epoch in the evolution of civilization ${ }^{92}$

A análise da biografia de Edwar Carr nos remete a outra obra biográfica de peso: Dostoevsky A Biography - His Life and Work ${ }^{93}$, escrita pelo importante intelectual soviético Leonid Grosmann e consultada e mencionada por Joseph Frank em Dostoiévski. Assim como ocorre na biografia de Carr, o local onde a obra foi produzida e as convicções políticas do biógrafo interferiram nos caminhos trilhados por Grossman na reconstituição da vida de Dostoiévski. Se Carr é um intelectual marxista afinado com a União Soviética, Grossman é um pesquisador que se encontra inserido nesse regime, e que, portanto, depara-se com limitações estruturais sem paralelo em outras tradições intelectuais para a realização do seu propósito. Por conseguinte, é possível mesurar as dificuldades que o biógrafo de Dostoiévski encontrou para discutir as opiniões políticas conservadoras e pró-czaristas do romancista russo.

É necessário atentar para o fato que, se por um lado o contexto político no qual Grossman atuou impôs certos obstáculos para a atividade de pesquisador especialista em Dostoiévski, por outro lado esta condição implicou na aproximação que nenhum outro biógrafo pôde ter com o escritor enquanto sujeito biografado - até agora mencionamos biógrafos de nacionalidade não russa e, no caso de Mochulsky, um russo emigrado. Portanto, Grossman foi o único que produziu a sua pesquisa no local onde Dostoiévski viveu a maior parte da sua vida - na amada Rússia natal - e que se beneficiou do contato com alguns dos contemporâneos de Dostoiévski - amigos e familiares.

\footnotetext{
${ }^{92}$ Idem, p. 245, 246.

${ }^{93}$ A obra de Grossman se encontra traduzida para o português por Boris Schnaiderman. A biografia foi intitulada Dostoiévski Artista. Editora Civilização Brasileira, 1967.
} 
As interessantes contribuições que o olhar de "dentro" trouxe para a empreitada biográfica são muito evidentes no texto. Por exemplo, assim como os demais biógrafos, Grossman utilizou as reminiscências e o diário de Anna Grigorievna, a segunda esposa de Dostoiévski, como fonte documental para a biografia. Mas, além dos textos aos quais todos igualmente tiveram acesso, o crítico soviético também se valeu do contato pessoal com a viúva do grande escritor. Dessa forma, os encontros e as conversas que o biógrafo travou com as pessoas que conheceram Dostoiévski aparecem na obra não somente como uma frutífera fonte de informação, mas como uma interessante estratégia de exposição de certos temas discutidos na biografia.

Dentre essas discussões merece ser mencionada a maneira como o biógrafo utiliza a sua proximidade com Anna para abordar a famosa carta que Strákhov endereçou à Tolstói, na qual ele se referiu a um suposto abuso sexual que Dostoiévski teria cometido contra uma criança. Assim, antes de se posicionar sobre o assunto, Grossman opta por reproduzir a reação da viúva a esta acusação durante uma conversa que ambos travaram no inverno de 1916-17:

The expression of her face changed as she broached the painful subject. She went on with noticeable emotion. 'You can imagine how painfully I reacted to the publication several years ago of Strakhov's letter, calling Fyodor Mikhailovich spiteful and dissolute and accusing him of crimes against morality. Everything turned black before my eyes from horror and indignation. What an incredible slander! And from whom! From our best friend, a constant visitor at our house, a witness at our wedding, from Nikolai Nikolaevich Strakhov, who after Fyodor Mikhailovich's death asked me to entrust him with the writing of his biography. If Nikolai Nikolaevich had been alive I would have gone to him at once despite my advanced years and have slapped his face for such baseness'. Anna Grigoryevna's pale cheeks flushed with indignation as she spoke. Her eyes sparkled with a youthful flame and her voice rang out in anger and injury. At that moment, the young girl in Victor Bobrov's well-known 
sketch on the margin of the finest engraving of Dostoevsky was clearly visible in the sweet old woman's face. There was the same burning look beneath finely drawn eyebrows. ${ }^{94}$

O excerto acima ilustra a relação de proximidade do estudioso soviético com a viúva de Dostoiévski e o discurso biográfico incorpora as impressões de Grossman sobre a reação de Anna a este dado controverso da vida do escritor russo. Ao descrever o sentimento de indignação que a sua interlocutora expressou durante a dolorosa conversa, Grossman pretendeu corroborar o seu ponto de vista sobre o ocorrido: que a carta não passou de uma falácia e que a acusação de Strakóv não tem base na realidade. Assim, a estratégia de incorporar as emoções e opiniões daqueles que conviveram com o escritor - sendo que essas "testemunhas" adquirem na obra do soviético um status de fontes confiáveis - é utilizada pelo biógrafo para validar as suas próprias apreciações a respeito da trajetória de vida do romancista russo. E a esta estratégia soma-se a intimidade com tudo o que cercou Dostoiévski - a experiência das minúcias do cotidiano nas cidades russas e do clima no país, o domínio da língua, o conhecimento profundo das questões políticas caras aos russos, entre outros.

Portanto, entre os méritos da biografia escrita por Grossman merece ser mencionado o olhar de "dentro" do biógrafo, assim como o método que norteia a investigação, ou, em outras palavras, a maneira como a obra biográfica prima por explicar como a ideologia de Dostoiévski foi se constituindo como resultante das leituras e experiências vivenciadas pelo escritor ao longo da sua vida e de como esta ideologia forjou a postura adotada pelo escritor diante do seu ofício. No entanto, em alguns momentos da obra é evidente o choque entre certos aspectos que constituem o amálgama ideológico de Dostoiévski e as convicções do biógrafo soviético.

\footnotetext{
94 GROSSMAN, Leonid. Dostoevsky - A biography. The Bobbs-Merrill Company, INC. Indianapolis/ New York, 1975, p. 245, 246.
} 
Dessa forma, o contexto no qual o biógrafo se encontra inserido salta os olhos quando o tema abordado é o posicionamento político de Dostoiévski. A opinião de Grossman é a de que Dostoiévski jamais foi um revolucionário, "not even in his youth"95. Para ele, os discursos inflamados que o romancista russo proferiu quando jovem nos círculos literários que frequentou eram um indicador do seu dom de artista e da sua capacidade de provocar efeito no público com as palavras, e não das suas reais convicções revolucionárias. Entretanto, mesmo sem ser revolucionário, o Dostoiévski da juventude cultivou convicções progressistas resultantes da identificação com o socialismo utópico. Mas, durante os quatros anos que ele vivenciou a prisão em Omsk, uma mudança significativa se operou nas suas convicções: ele descartou o socialismo utópico e passou a conceber a viabilidade da aproximação com o povo por meio da religião Ortodoxa. Grossman indaga "when did Dostoevsky experience his religious crises?"e a seguir responde "we think that the execution on 22 December 1849 was the turning point" 96 .

Assim, os efeitos dessa transformação se fazem sentir quando de volta do exílio o escritor se dedica à atividade jornalística a frente de revistas como $O$ Tempo e A Época, publicações que na visão de Grossman "may have been conservative" "97, mas que mesmo assim assumiram posturas louváveis com relação a alguns temas - o biógrafo cita a atitude criativa da $A$ Época referente à literatura russa, ou a posição moderada de O Tempo nas questões políticas do momento e a defesa da revista à emancipação dos servos. A identificação com o conservadorismo reacionário, no entanto, viria mais tarde, mais especificamente em 1864, ano marcado por tragédias pessoais como a morte da primeira esposa, do irmão de Dostoiévski e a falência da revista $A$ Época, seguida pelo

\footnotetext{
${ }^{95}$ Idem, p. 107.

${ }^{96}$ Idem, p. 184.

${ }^{97}$ Idem, p. 308.
} 
endividamento financeiro do escritor. Na visão de Grossman, no entanto, uma tragédia maior ainda ocorreu nesse "terrible year" da vida de Dostoiévski e, como o espinho na rosa, nunca mais se dissociou da imagem do escritor russo mesmo com toda a glória que a posteridade o reservou. Assim, 1864:

brought the definitive turning-point in his ideology. He took a stand which has always proved disastrous, even for the greatest of writers: He come-out in defense of reaction and against the progressive forces of his Day. This was probably the ultimate tragedy of his whole tormented life. As an artist, Dostoevsky retained his creative talent, but as a fighter and political thinker he had been blown back by the gale of history into the camp of the dark and sinister forces of the age ${ }^{98}$

Destaca-se, portanto, a maneira como Grossman lamenta a virada à direita de Dostoievski e como ele, ao contrário de outros biógrafos - dentre os quais Joseph Frank - sustenta que se por um lado o legado artístico do romancista é esplêndido, por outro lado o seu legado político é condenável. Este juízo, por sua vez, adquire aos olhos do leitor os contornos de uma sincera reprovação mesclada com um sentimento de pesar da parte do biógrafo e reaparece a partir deste momento em algumas outras passagens da obra. Isso ocorre, por exemplo, quando o biógrafo comenta a atuação de Dostoiévski como o editor do periódico semanal extremamente conservador $O$ Cidadão. Após ser apresentado ao príncipe Mechtchérski por Strákhov, Dostoiévski aceita o convite para assumir o jornal dirigido pelo príncipe, o que, na visão de Grossman, "to have become na associate of this kind of political manipulator was a lamentable event in Dostoevsky's life and probably the greatest mistake he ever made" 99 .

\footnotetext{
${ }^{98}$ Idem, p. 309.

${ }^{99}$ Idem, p. 489.
} 
Postura semelhante da parte do estudioso soviético é identificável no trecho em que ele comenta a proximidade de Dostoiévski, nos últimos anos da sua vida, com proeminentes ideólogos da reação como Kátkov, Pobedonóstsev, entre outros. Este último foi o responsável por introduzir Dostoiévski nos círculos sociais que orbitavam ao redor da corte, assim como foi quem apresentou o já célebre escritor russo aos membros da família imperial. O Czar então confiou à Dostoiévski a educação e o aconselhamento dos herdeiros do trono. Assim, nos seus últimos anos, Dostoiévski foi aceito no mundo da alta nobreza e do poder imperial e o escritor "who had never belonged to the highest nobility either by origin, profession, or way of life, now, at the end of his life, had most of his social contacts in this sat, and strove to become the exponent of its socio-political views"100 . O biógrafo relembra com uma ponta de ironia que os ambientes da aristocracia nada lembravam os ambientes nos quais Dostoiévski circulou durante a maior parte da sua vida: o bairro pobre da infância, a pequena residência de madeira em Staraya Kolomna de Petrachévski onde ele entrou em contato com as ideias do socialismo utópico, a prisão, as casa de jogo etc.

Portanto, em poucas palavras, a conclusão de Grossman é que "politically, Dostoevsky's lot was a tragic one"101. Mas esse destino trágico não interferiu na grandeza da sua obra (assim como o contrário também não ocorreu, ou seja, a grandeza da obra não redimiu os tropeços na política). Segundo Grossman, do ponto de vista dos princípios estruturais da obra de Dostoiévski, Os Irmãos Karamázov é o ápice do desenvolvimento do escritor como artista literário. Nesse romance, que se configura como um "multi-voiced yet harmonious epilogue to all his turbulent work"102 a polifonia (segundo o conceito cunhado por Bakhtin), que é a grande inovação artística

\footnotetext{
${ }^{100}$ Idem, p. 557, 558.

${ }^{101}$ Idem, p. 556.

${ }^{102}$ Idem, p. 593.
} 
criada por Dostoiévski, atinge a sua forma mais bem acabada, uma vez que "it's not however the ideologue of Pobedonostsev's Russia, or the preacher of theocracy, who triumphs, but the great master of the philosophical novel". ${ }^{103}$ Assim, ao criar o romance polifônico, o grande escritor russo evitou que a tragédia do seu destino político se abatesse sobre a sua grande obra literária, preservando dessa forma o interesse deste legado artístico para as gerações vindouras. Esta é a leitura de Grossman, que compôs a sua biografia ocupando duas posições conflitantes: a de especialista em Dostoiévski e a de pesquisador na união Soviética.

A imagem da tragédia como inerente ao destino do escritor russo também aparece em outra obra biográfica digna de menção: Dostoïevski, da autoria do importante intelectual austríaco Stefan Zweig. Dostö̈evski figura entre as obras biográficas mais importantes já escritas sobre o escritor russo, tendo sido inclusive consultada por Freud quando este elaborou o seu já mencionado artigo Dostoiévski e o Parricídio. Mas, ao contrário de Grossman, Zweig acredita que a tragédia não se restringiu ao destino político do escritor russo, mas foi a grande marca da vida de Dostoiévski em todas as suas esferas, sendo a superação dessa grande tragédia o principal dado de interesse da vida em questão.

Nas palavras do biógrafo "si, au regard de l'artiste, la vie de Dostö̈evski est une tragédie, elle est au point de vue moral une conquête sans pareille, um triomphe de l'homme sur as destinée, une transformation de la vie extérieure par une force magique intérieure" ${ }^{104}$. Zweig enxerga o triunfo de Dostoiévski sobre os infortúnios do seu destino como o resultado da mobilização dos recursos internos contra as fatalidades externas, portanto como uma atitude ativa e nada complacente com os desígnios da

\footnotetext{
103 Idem, p. 593.

${ }^{104}$ ZWEIG, Stefan. Dostö̈evsky, Paris: Les ÉditionsRieder, 1929, p. 55.
} 
Providência e, acima de tudo, como um ato de superioridade moral. Dessa maneira “(...) Dostoïevski, ce ser de la destinée, est le grand triomphateur de la souffrance,(...) seuls les coups du destin ont fait sa force; les coups de marteau qui s'abattent sur l'enclume de son existence forgent sa puissance intérieure" ${ }^{\text {105 }}$.

O mergulho de Zweig nessa natureza desmedida se deu por meios heterodoxos em comparação com os caminhos habitualmente percorridos pelos autores que se aventuram no gênero biográfico. O método para a compreensão da vida e da personalidade do romancista russo não se baseou apenas no levantamento e no estudo sistemático da documentação disponível, mas em um esforço de autoconhecimento e introspecção. Refletir sobre o destino tortuoso de Dostoiévski foi também para Zweig refletir sobre si próprio, sobre o seu lugar no mundo e sobre sua missão enquanto homem e enquanto escritor. Dessa forma, deparamo-nos com uma experiência biográfica totalmente diferente das outras analisadas anteriormente. Podemos classificar Dostö̈evski como biografia como “moyen d'expression”, segundo a definição de André Maurois $^{106}$.

Esta nova forma de biografia, forjada em função do objetivo que move o biógrafo, é essencialmente distinta das formas biográficas analisadas até aqui. Esta não se aproxima da ficção e nem se preocupa com a baliza das fontes documentais exatamente porque ela se coloca acima dessas questões, uma vez que transcende os limites da biografia e consiste, acima de qualquer coisa, em uma obra de arte. Dessa forma, Zweig lançou mão do gênero biográfico na medida em que este se apresentou

\footnotetext{
105 Idem, p. 50.

106 "La biographie consedérée comme moyen d'expression, c'est celle dont Le sujet a été choisi par l'auteur pour répondre à um besoin secret de as nature. Elle sera écrit avec une émotion plus naturelle qu'une autre, parce qu'a travers les sentiments et les aventures du personage s'exprimeront les sentiments du biographe lui-même: elle sera, dans une certain mesure, une autobiographie déguisée en biographie". MAUROIS, Op. Cit., p. 111.
} 
como um meio viável para o alcance da sua finalidade principal: a composição de um experimento artístico.

É interessante ressaltar que a eleição da vida de Dostoiévski como o tema da sua próxima obra não foi uma escolha fácil para o jovem Zweig. A idéia da biografia surge quando os primeiros ecos da Primeira Grande Guerra já se faziam ouvir, e a redação começa no mesmo momento em que eclode o conflito. A posição de Zweig era determinantemente contrária à guerra, uma vez que o escritor repudiava ações violentas e se autointitulava pacifista. Além disso, o estilo de vida do jovem Zweig era o de um “cidadão do mundo", pois ele não tinha vínculos profundos com o seu país de nascimento e tinha uma enorme curiosidade com relação às diferentes culturas e aos diferentes modos de vida. Ele fixou residência em alguns países da Europa (viveu principalmente na França) e ao longo da vida viajou para muitos lugares, tendo explorado países do mundo todo (faleceu no Brasil). Por conseguinte, foi com muito pesar que recebera a notícia de que os países do velho continente se digladiariam no que de fato foi uma das guerras mais sangrentas da história.

Segundo um dos seus biógrafos, o jornalista brasileiro Alberto Dines, "para Zweig, os ventos de mudança trazem o primeiro dilema biográfico, na verdade a primeira grande opção existencial". ${ }^{107}$ Isso porque antes de se decidir por Dostoiévski, o escritor cogitara escrever uma biografia de Balzac, e na visão de Dines esse impasse é significativo e revelador da leitura arguta que Zweig empreendeu do seu tempo histórico. Isso porque "Balzac e Dostoiévski disputam não apenas o seu interesse intelectual, mas se oferecem como alternativas. (..) A fábrica de romances do francês e os tormentos do russo compõe um painel do teimoso e infindável século XIX. Ao somálos, Zweig verifica os sinais da desintegração da estabilidade que o ser burguês inventou

\footnotetext{
${ }^{107}$ DINES, Alberto. Morte no Paraíso. Rio de Janeiro: Rocco, 2004, $3^{\circ}$ Edição ampliada, p. 123.
} 
para imaginar-se feliz. Ambos foram envolvidos pelo turbilhão de 1848, que só então, mais de meio século depois, começava a se materializar. Como o jornalista que responde aos eventos do dia, Zweig vive o presente através da atmosfera espiritual do passado. Na véspera de uma era ainda sem nome, o austríaco prepara-se para enterrar a anterior. O russo ganha a parada porque oferece mistério e dúvida. Balzac, óbvio e vital, ficará para depois"

Dessa maneira, Dostoiévski não desponta como um simples biografado, mas como uma personalidade capaz de dizer algo ao seu biógrafo e de oferecer respostas acerca de um futuro dolorosamente incerto. $\mathrm{O}$ duro destino do gênio russo, no qual o biógrafo descobre um sentido superior, soa como uma esperança diante da sombra que a iminência da guerra projeta sobre o destino de Zweig e o de todos os europeus. Nas palavras de outra biógrafa do escritor austríaco, Dominique Bona, "O contraste é gritante, em 1913, entre esse romancista russo, que enfrentou muitas dificuldades, e o jovem escritor austríaco, virgem de provas, inocente e entusiasta, que pressente, porém, com todos os seus nervos, os sofrimentos morais que terá em breve que padecer, e se prepara, procurando ajuda junto aos heróis do seu coração, para encarar um futuro que toma as cores da noite" ${ }^{\prime 109}$.

A opção por Dostoiévski, além de indicar uma notável sensibilidade de Zweig para as vicissitudes da história, também ressignificou o sentido da sua obra. "Toda rota intelectual de Zweig pode ser compreendida nessa primeira escolha" ${ }^{\text {"10 }}$ e o epíteto do livro retirado da frase de Goethe "Ne pas aboutir fait ta grandeur" tornou-se o fio condutor das suas biografias posteriores. A partir dessa escolha ele encontrou um norte para a sua obra futura e se transformou no grande biógrafo das vidas fraturadas e

\footnotetext{
${ }^{108}$ Idem, p. 123, 124.

${ }^{109}$ BONA, Dominique. Stefan Zweig. Rio de Janeiro: Record, 1999, p.101.

${ }^{110}$ Idem, p. 99.
} 
inacabadas. As histórias para as quais ele se voltou foram as de Erasmo, Maria Antonieta, Fouché, Maria Stuart, entre outros, em um claro sinal de que seu interesse fora definitivamente capturado por homens e mulheres cuja grandeza na vida advém dos seus mais destacados fracassos.

A análise da trajetória de Stefan Zweig precipita-nos para os fáceis (e falsos) caminhos da história retrospectiva. Zweig, o biógrafo dos destinos trágicos, também vivenciou uma grande tragédia. Retrato do século em que viveu - o século XX, os cem anos nos quais o "horror engolfou a história""111 - Zweig suicidou-se em Petrópolis, no Rio de Janeiro, após fugir da perseguição aos judeus comandada pelo Nazismo e de testemunhar as duas Grandes Guerras que arrasaram o velho continente, tendo a primeira inaugurado uma escala de destruição em massa inédita superada apenas pela segunda, o seu desdobramento histórico. O biógrafo de Dostoiévski, que sucumbiu perante os horrores da História, não pressentiu ou sequer imaginou o seu triste fim, mas o leitor do presente familiarizado com o que se passou pode localizar no ciclo das obras de Zweig iniciado por Dostö̈evski o processo de identificação do biógrafo com o seu biografado, seguido da revelação de si através da biografia dedicada a outra pessoa. No caso do escritor austríaco, assim como os seus biografados, a maneira como ele viveu (e morreu) é exemplar da sua convicção de que "só é homem, no sentido pleno da palavra, quem foi magoado e conheceu a humilhação. O 'ganhador', esse monólito, não tem lugar em um mundo onde o fracasso é mais revelador que a vitória, mais propício ao desabrochar de um coração" "112. Convicção esta que foi tomando forma e adquirido sentido a cada nova empreitada biográfica.

\footnotetext{
${ }^{111}$ SEVCENKO, Nicolau. A Corrida Para o Século XXI: no loop da montanha-russa. São Paulo: Companhia das Letras, 2001, p. 16.

${ }^{112}$ BONA, Op. Cit., p. 99.
} 
Em suma, o panorama que emerge da análise dessas obras tão distintas é o de uma infinidade de possibilidades biográficas que não se anulam, mas, pelo contrário, enriquecem-se umas às outras legitimando a característica "hiperbiografável" que se associou à persona Dostoiévski. Tendo em vista a tradição biográfica solidificada sobre a vida do escritor russo, é digno de nota o fato de Joseph Frank destacar-se como " $O$ " biógrafo de Dostoiévski. No obituário de Frank, publicado no jornal norte-americano The New York Times em março de 2013, consta a afirmação do eslavísta Gary Saul Morson sobre a biografia em cinco volumes: "it's now regarded as the best biography of Dostoevsky in any language, including Russian, which is really saying something"113. A opinião de Morson, mesmo tendo em vista que a eleição de uma obra como "a melhor" entre tantas outras nunca é isenta de conflitos, ilustra a centralidade de Dostoevsky de Joseph Frank na tradição biográfica sobre a vida do escritor russo.

Como afirmou Dante Moreira Leite sobre o gênero biográfico: "toda biografia é trabalho de interpretação e, portanto, de imaginação criadora. Por isso, nenhuma biografia é definitiva, e sempre será possível refazê-la, com base em dados basicamente iguais, pois todo biógrafo faz viver o biografado, mais ou menos como o ficcionista faz viver as personagens de sua imaginação"114 . Assim, nenhuma biografia, por mais bem sucedida que seja, esgota as possibilidades que esse gênero oferece para a narração da uma vida. De qualquer maneira, é inegável que algumas biografias aproximam-se mais do que outras da utopia da "biografia definitiva". Dostoiévski, de Joseph Frank, é uma delas.

113 WEBER, Bruce “Joseph Frank, Biographer of Dostoevsky, Dies at 94”. Disponível em: www.nytimes.com/2013/03/04/arts/joseph-frank-biographer-of-dostoevsky-dies-at94.html?ref=obituaries \&-r=1

${ }^{114}$ LEITE, Dante Moreira, O Amor Romântico e Outros Temas. São Paulo: Edusp, 1979, p. 43. 


\section{Dostoiévski de Joseph Frank}

O biógrafo Joseph Frank foi professor emérito das universidades norteamericanas de Princeton e Stanford. Em Princeton, ocupou uma cadeira no Departamento de Literatura Comparada, e em Stanford foi professor do Departamento de Literaturas, Culturas e Línguas. O seu percurso acadêmico pode ser dividido em dois momentos: o primeiro momento é marcado pelo sucesso do ensaio "Spatial Form in Modern Literature", publicado no ano de 1945 na Sewanee Review, que foi posteriormente agrupado a outros ensaios e apareceu em livro - The Widening Gyre - no ano de 1963 e que se tornou um clássico dos estudos da narrativa e o projetou como um importante teórico da literatura, dedicado à estética do romance moderno. Já o segundo momento distingue-se pelo seu interesse crescente pela literatura russa, particularmente pela obra Memórias do Subsolo e pela produção artística de Dostoiévski. Este interesse cada vez maior pelo universo dostoievskiano culminou na monumental biografia sobre a vida do escritor russo. $\mathrm{Na}$ atualidade, Joseph Frank é considerado um dos maiores especialistas em Dostoiévski da academia norte-americana. A biografia Dostoiévski recebeu importantes prêmios literários: Christian Gauss Award (duas vezes), National Book Critics Circle Award, Russian Etkind Prize da Universidade de São Petersburgo.

Uma breve explanação do percurso intelectual e acadêmico de Joseph Frank nos permite concluir que antes de biógrafo de Dostoiévski, Frank é um crítico da literatura e, portanto, foi com o olhar de crítico que ele se debruçou sobre a vida do escritor russo. Isso explica a opção pelo método de análise feita pelo autor, justificada nos prefácios dos volumes da biografia: um movimento que vai da obra para a vida, e não o contrário. É em função desse interesse circunscrito de Frank pela obra de Dostoiévski que a biografia tem a produção literária do escritor russo como eixo. Os incidentes pessoais, 
os detalhes da intimidade que geralmente recheiam as biografias convencionais foram deslocados para o segundo plano, pois, nas suas palavras, "quando escrevo o que está por trás dos acontecimentos da vida particular de Dostoiévski, apenas me aprofundo nos aspectos dessa experiência cotidiana que parecem ter alguma importância decisiva - ou seja, naqueles que ajudam a compreender melhor os seus livros" ${ }^{\prime 15}$.

Dessa maneira, já é possível divisar algumas diferenças importantes entre a biografia de Frank e as demais biografias analisadas. A obra Dostoiévski iniciou-se na década de $1970^{116}$, portanto, em comparação com as outras biografias estudadas é a mais atual. O seu último volume ${ }^{117}$, por sua vez, foi lançado em 2002. Assim, além de ser a mais recente entre todas as biografias comentadas até aqui, a sua elaboração se estendeu por quase três décadas, acompanhando, dessa forma, o aprofundamento dos atuais debates teóricos e metodológicos sobre o gênero biográfico.

É oportuno notar o quanto esta obra reflete as transformações que ocorreram nas concepções acerca da biografia nos últimos quarenta anos. Logo no prefácio do primeiro volume nos deparamos com a seguinte afirmação do autor: que o seu trabalho "não é uma biografia""118. A recusa de Joseph Frank em se identificar como um autor de biografias é uma atitude que se explica em função da época na qual essas palavras foram escritas, pois até meados da década de 80 , como já mencionado, a biografia foi desprezada pela academia. O prefácio data de fevereiro de 1976, portanto de um período no qual ainda prevalecia o desinteresse dos eruditos e acadêmicos pelo gênero biográfico. Já no prefácio do segundo volume, escrito em 1982, Frank começa a rever a

\footnotetext{
${ }^{115}$ FRANK, Joseph, Dostoiévski:As Sementes da Revolta1821 - 1849. São Paulo: Edusp, 2008. 2. ed. rev., p. 16.

${ }_{116}$ O primeiro volume Dostoevsky: The Seeds of Revolt 1821-1849 (Dostoiévski: As Sementes da Revolta 1821-1849), lançado pela Princeton University Press, data de 1976.

117 Dostoevsky: The Mantle of Prophet, 1871-1881 (Dostoiévski: O Manto do Profeta 1871-1881), também publicado pela Princeton University Press.

${ }^{118}$ Idem, p. 16, 17.
} 
sua posição sobre o "gênero" da sua obra. Ele pondera: "fiz uma distinção demasiado rígida quando afirmei no primeiro livro que "meu trabalho não (...) é uma biografia”. O que ele reitera é o fato da sua biografia não se tratar de uma "biografia convencional", mas, como sugeriram alguns dos seus críticos, de "uma bem-vinda tentativa de estender os limites desse gênero"119.

Já foi sugerido que o que assegurou a sobrevivência da biografia, apesar das contundentes críticas à sua pertinência enquanto gênero literário foi a atitude dos biógrafos conscientes dessas mesmas críticas, que ao invés de negá-las, aproveitaramnas como mote da atual produção biográfica. Novas experimentações sucederam à incontornável problematização do gênero. Tendo em vista a tipologia elaborada por Giovanni Levi, é possível afirmar que a tentativa de Frank de "estender os limites do gênero" desembocou na exploração das possibilidades imbricadas na forma da biografia e contexto.

Esse tipo de utilização da biografia, segundo Levi, estrutura-se a partir de uma hipótese fundamental: "qualquer que seja a sua originalidade aparente, uma vida não pode ser compreendida unicamente através de seus desvios ou singularidades, mas, ao contrário, mostrando-se que cada desvio aparente em relação às normas ocorre em um contexto histórico que o justifica" ${ }^{\text {"20 }}$. É possível afirmar que essa mesma hipótese figura no cerne de Dostoiévski, pois a opção pela biografia e contexto foi condicionada pela visão de Frank sobre a produção literária do escritor russo, que para ele só se torna inteligível na medida em que o contexto no qual estas obras foram gestadas é esclarecido. Na opinião de Frank, os temas de Dostoiévski não podem ser dissociados

\footnotetext{
${ }^{119}$ FRANK, Joseph, Dostoiévski: Os Anos de Provação 1850-1859. São Paulo: Edusp, 2008. 2. ed. rev., p. $15,16$.

${ }^{120}$ LEVI, Giovanni "Usos da biografia" IN: FERREIRA, Marieta de Moraes e AMADO, Janaina (orgs) Op. Cit., p. 176.
} 
das grandes questões do seu tempo e a justa interpretação da obra do artista pressupõe que ao invés de "dedicar espaço aos incidentes rotineiros da vida de Dostoiévski" o biógrafo detenha-se "na observação do ambiente sócio-cultural em que ele viveu"121. No prefácio do último volume ele afirma que escreveu a partir da vida de Dostoiévski uma história cultural da Rússia do século XIX.

Portanto, o fio condutor de Dostoiévski é a certeza da necessidade da reconstituição do contexto histórico. E nesse aspecto Frank realizou um trabalho de fôlego, no qual se evidencia o comprometimento com as fontes documentais e o repúdio ao recurso à ficção. Frank se esforça para delimitar com precisão o que pertence ao terreno dos fatos e o que pertence ao terreno da especulação. Dessa forma, a biografia busca compreender a obra e a vida à qual esta se encontra irremediavelmente ligada a partir do método histórico fundamental de comparação e confirmação das fontes variadas.

A pesquisa que Frank realizou para elaborar a obra abrangeu as biografias fundamentais escritas sobre a vida do escritor russo, a documentação primária como, por exemplo, as cartas de Dostoiévski ou as reminiscências dos seus familiares e amigos consultadas na língua original e também nas traduções para o inglês (sempre nesse caso em cotejo com as originais) e, por fim, parte da literatura crítica disponível sobre a produção literária de Dostoiévski, publicada principalmente em russo e em inglês.

Como mencionado no capítulo anterior, Frank cita com frequência nos volumes da sua obra as biografias da autoria de Leonid Grossman e de Konstantin Mochulsky, como também a primeira biografia escrita sobre Dostoiévski, elaborada logo após a morte do escritor por Strákhov e Orest Miller. Entre as fontes primárias consultadas

\footnotetext{
${ }^{121}$ FRANK, Joseph, Dostoiévski:As Sementes da Revolta1821- 1849. São Paulo: Edusp, 2008. 2. ed. rev.,
} p. 17 . 
merecem ser mencionadas a correspondência de Dostoiévski editada por A. S. Dolinin (em russo), assim como as memórias de pessoas que conviveram com o escritor como as de Andrei, o irmão caçula ("F. M. Dostoevsky v Vospominaniakh Sovremmenikov", editada por A. S. Dolin ${ }^{122}$ ) que aparecem citadas nos primeiro volume, as memórias do barão Wrangel ("Vospominaniya o F. M. Dostoevskom v Siberii",123), mencionadas no segundo volume, os escritos deixados pela segunda esposa de Dostoiévski ${ }^{124}$, fonte recorrentemente examinada na biografia, entre outras.

Por fim, é importante ressaltar que o biógrafo norte-americano estabelece um diálogo profícuo com a bibliografia disponível sobre Fiódor Dostoiévski produzida tanto pelos estudiosos russos e soviéticos quanto pelos especialistas norte-americanos. Para alguns colegas de Joseph Frank, dentre os quais Robin Feuer Miller, o biógrafo não se aprofunda na discussão da bibliografia Ocidental disponível e comete um deslize ao apenas mencionar passageiramente - e em muitos casos nem mesmo citar importantes trabalhos de scholars norte-americanos dedicados aos romances da maturidade de Dostoiévski. Nas palavras de Miller "No one else is better situated to offer such a response, and it is a disappointment not to find this engagement" ${ }^{\text {"125 }}$. Nos primeiros volumes, de fato, Frank pouco cita os estudiosos do seu país. Há menção a alguns trabalhos de scholars norte-americanos em The Seeds of Revolt 1821-1849 ${ }^{126}$, mas é notória a predominância da literatura crítica produzida pelos soviéticos sobre a norte-americana. Assim, no primeiro volume abundam autores como Bakhtin, Chestov, Komarovich, entre outros. No volume seguinte ocorre algo semelhante, mas a partir do

\footnotetext{
${ }^{122}$ Reprodução da referência conforme citada na edição norte-americana The Seeds of Revolt 1821-1849, Princeton N. J: Princeton University Press, 1976.

${ }_{123}$ Reprodução da referência conforme citada na edição norte-americana The Years of Ordeal 18501859,Princeton, N.J: Princeton University Press, 1983.

${ }^{124}$ DOSTOEVSKY, Anna. Reminicences, trans. And ed. Beatrice Stillman, New York, 1975.

${ }^{125}$ MILLER, Robin Feuer. "Frank's Dostoevsky". The Slavic and East European Journal, Vol. 47, $\mathrm{N}^{\circ} 3$ (Autumn, 2003), p. 475.

${ }^{126}$ É citada, entre outras, a obra: TERRAS, Victor. The Young Dostoevsky 1846-1849. The Hague, 1969.
} 
terceiro volume, ao contrário do que escreveu Miller, Frank começa a dar mais atenção para a crítica Ocidental. Estudiosos como Robert L. Jackson, Abott Gleason, D. S. Savage e mesmo Robin F. Miller recebem mais espaço de discussão do que os autores soviéticos. No quinto e último volume, por sua vez, a literatura Ocidental ganha um destaque considerável. Goldstein é evocado na discussão referente ao antissemitismo de Dostoiévski $^{127}$, Marcus C. Levitt ${ }^{128}$ é citado na reconstituição que Frank realiza do Festival Púchkin e, por fim, muitos estudiosos norte-americanos (e britânicos) são mencionados nos capítulos dedicados a Os Irmãos Karamázov: Victor Terras, Diane O. Thompson, Robin Feuer Miller, Natham Rosen, W. J. Leatherbarrow ${ }^{129}$, entre outros.

O monumental projeto de Joseph Frank recebeu apoio financeiro de importantes fundações norte-americanas ${ }^{130} \mathrm{e}$ recursos de universidades $^{131}$. Frank manteve-se vinculado ao longo desses trinta anos de trabalho aos centros e institutos de pesquisa das principais universidades norte-americanas ${ }^{132}$ e francesas $^{133}$ (na França Frank também elaborou a sua pesquisa no âmbito institucional de importantes bibliotecas ${ }^{134}$ ). A circulação de Joseph Frank no ambiente acadêmico francês durante a elaboração da biografia foi tão profícua que em 1999 ele foi agraciado com o "honorary doctorate award", concedido pela Sorbonne.

\footnotetext{
${ }^{127}$ GOLDSTEIN, David I. Dostoevsky and the Jews. Texas: University of Texas Press, 1981.

${ }^{128}$ LEVITT, Marcus C. Russian Literary Politics and the Pushkin Celebration of 1880. Ithaca, 1989.

${ }^{129}$ TERRAS, Victor, A Karamazov Companion. Madison, 1981; THOMPSON, Dianne, O. The Brothers Karamazov and the Poetics of Memory, Cambridge, 1991; MILLER, Robin Feuer. The Brothers Karamazov. New York, 1992; ROSEN, Nathan, "Style and Structure in The Brothers Karamazov", na edição crítica da Norton The Brothers Karamazov. New York. 1976; LEATHERBARROW, W. J. The Bothers Karamazov. Cambridge, 1922.

${ }^{130}$ Como, por exemplo, a Guggenheim Foundation e Rockefeller Foundation.

${ }^{131}$ Como, por exemplo, The Princeton Research Council, Center for International Studies at Stanford University, entre outros.

${ }^{132}$ Stanford, Princeton, Harvard.

${ }^{133}$ Institut des Études Slaves, em Paris.

${ }^{134}$ Bibliothèque de la Sorbonne, Bibliothèque des Langue Orientales e Bibliothèque du Institut d'Études Slaves de Paris.
} 
Cabe ressaltar que em todas essas décadas de trabalho Frank se dirigiu à Rússia com fins de pesquisa somente uma vez ${ }^{135}$. Esse dado é relevante, pois lança luz sobre o fato deste trabalho monumental ter sido elaborado com base nas universidades de ponta norte-americanas e francesas e com pesquisa da documentação disponível nessas instituições. Isso diferencia esta biografia das obras produzidas pelos especialistas de nacionalidade russa como a escrita por Grossman, já discutida anteriormente, uma vez que se trata de uma biografia da autoria de alguém pouco familiarizado com a cultura e o local no qual Dostoiévski viveu, cujo olhar é externo e o domínio sobre o assunto é livresco, ao contrário da obra do estudioso soviético na qual se evidencia a proximidade com tudo que envolve o sujeito biografado.

De qualquer maneira, a distância física do local onde se desenrolaram os acontecimentos vivenciados por Dostoiévski não impediu Joseph Frank de construir um conhecimento sólido sobre a história da Rússia do século XIX. Como afirmou um estudioso norte-americano em uma resenha sobre o quarto volume da biografia: "Frank is also an excellent intellectual and cultural historian, who knows the Russian ideological politics of Dostoevsky's time as well as anyone alive"136. Portanto, a reconstituição acurada do contexto histórico no qual a vida de Dostoiévski se desenrolou e a maneira como o biógrafo ressalta que o escritor não foi apenas um homem do seu tempo, mas também um agente do seu tempo, são as principais contribuições para os estudos dostoievskianos oferecidas por esta obra biográfica. Além disso, como já mencionado, este esforço de reconstituição de toda uma época histórica é o que caracteriza o método de aproximação biográfica utilizado por Joseph Frank.

\footnotetext{
${ }^{135}$ Como é possível inferir com base nas informações disponíveis na biografia, Frank viajou à Rússia com fins de pesquisa enquanto preparava o quarto volume The Miraculous Years, quando the foi concedida uma bolsa para uma viagem a São Petersburgo pelo Center for International Studies at Stanford University.

${ }^{136}$ GLEASON, Abbot . "Untitled". Russian Review, Vol. 55, No. 2 (Apr., 1996), p. 325.
} 
No volume três, Os Efeitos da Libertação 1860-1865, este método é destrinchado aos olhos do leitor. Neste volume consta a análise de Memórias do Subsolo, a obra de Dostoiévski que primeiro interessou Frank e que motivou o crítico a se aventurar na empreitada da reconstituição da vida do escritor russo. Essa obra, na visão do biógrafo, exemplifica a particularidade do gênio de Dostoiévski e apresenta uma característica que estará presente em todos os romances da maturidade do escritor russo: a preocupação com os grandes temas (os temas universais) caminhando lado a lado com o interesse pelas questões colocadas pelo período histórico que Dostoiévski vivenciou.

Em Os Efeitos da Libertação Frank lança luz sobre as questões malditas que tanto preocuparam Dostoiévski, que segundo o biógrafo são discutidas no texto produzido pelo escritor no momento em que ele velou o corpo da sua primeira esposa. Intitulado "Voltarei a ver Macha algum dia?", esse texto é, na visão do biógrafo, a principal fonte para a compreensão das inquietações de Dostoiévski. Nas palavras de Frank: "surpreendentemente, pouca atenção se deu a esse documento fundamental, mesmo que nada mais que brotou da pena de Dostoiévski nos leve de forma tão direta ao fundo de seus sentimentos-ideia religiosas" ${ }^{137}$.

Neste texto, Dostoiévski expressa as suas opiniões a respeito do bem e do mal, da imortalidade, da importância de Cristo e do sentido da vida. O título do texto remete o leitor de pronto à questão da dúvida a respeito da existência da vida eterna após a morte, questão que já atormentara Dostoiévski anos antes, quando ele se viu diante do pelotão de fuzilamento. Naquela ocasião, o jovem escritor se apegou à perspectiva da existência da imortalidade, e no momento em que a morte da esposa ofereceu-lhe

\footnotetext{
137 Frank, Joseph. Dostoiévski - Os Efeitos da Libertação (1860-1865). São Paulo: Editora da Universidade de São Paulo, 2002, p. 410.
} 
motivo para refletir novamente sobre o assunto ele se esforçou, nas palavras de Frank, “não só para convencer-se de que a imortalidade existe, como também para explicar por que ela deve ser um complemento necessário da vida humana na terra"138.

O segundo motivo sobre o qual Dostoiévski discorre nesse texto chave é a oposição entre as leis de Cristo e o egoísmo. A necessidade da personalidade humana de possuir autonomia se choca, de acordo com esse raciocínio, com as leis de Cristo (dentre as quais amar ao próximo como a si mesmo). Para o escritor russo, é obrigação dos homens sufocar o egoísmo em favor dos ensinamentos cristãos. Assim, segundo Frank, a fé de Dostoiévski é o resultado de uma escolha, de natureza "condicional", e quando ele escreveu a Sra. Fonvízina afirmando que se alguém demonstrasse que a verdade estava fora de Cristo ele optaria por permanecer com Cristo, ele não estava expressando as reticências da sua fé, mas ao contrário a força da sua opção por Cristo.

Assim, para Joseph Frank, "todas as obras importantes de Dostoiévski serão controladas pelo quadro de valores expresso nessa anotação de seu caderno e dramatizarão, de uma maneira ou de outra, a fatal oposição entre a lei de Cristo e a lei da personalidade tal como entendia Dostoiévski. (...) Para compreender Dostoiévski, devemos tentar apreender sua forma particular de entender esse grande tema, que ele completa, desenvolve e dramatiza em termos das questões e conflitos socioculturais da sua época. Esses conflitos fornecem-lhe a substância viva da sua obra; é através deles que ele se ergue aos píncaros do grande argumento que se apossou de seu espírito e inflamou sua imaginação criativa; e sua genialidade consiste exatamente na capacidade de unir esses dois níveis (à primeira vista) tão diferentes" ${ }^{\text {"139 }}$.

\footnotetext{
${ }^{138}$ Idem, p. 411.

${ }^{139}$ Idem, p. 425.
} 
Esta passagem da obra de Frank é fundamental, pois esclarece a direção que o biógrafo vai seguir na análise da ficção dostoievskiana. Para Frank, o "quadro de valores" desenhado por essas notas estará presente nas obras do escritor. Como, no entanto, a interpretação dos romances de Dostoiévski esbarra na polêmica sobre o fim do "paternalismo" em literatura, se ele expressou ou não as suas próprias ideias nos seus romances ainda é um assunto em discussão, assim como é controversa a leitura que sugere que este "quadro de valores" corresponde à defesa da moral do cristianismo.

Segundo Frank, a experiência de encarceramento fez com que Dostoiévski se convencesse da "fragilidade e insignificância da razão, quando confrontada com as situações críticas da existência humana"140. Diante dessa descoberta, todas as dúvidas tão características do seu tempo quanto à fé se dissiparam, pois Dostoiévski passou a separar por completo fé e razão humana, elaborando dessa forma um antídoto para essas mesmas dúvidas que antes o atormentavam e abalavam a sua condição de crente. É interessante que Joseph Frank descreve essa fé “inabalável” de Dostoiévski nos termos dialéticos que Kierkegaard expressou a sua, e sustenta que a "apaixonada interiorização" dos preceitos da fé compensou a "incerteza objetiva" da crença em Deus e em Cristo. Assim, Frank mantém a opinião de que, apesar de instável, a fé de Dostoiévski se coloca "acima do abismo da dúvida""

Muitos outros biógrafos e estudiosos enxergam de forma diferente de Joseph Frank essa delicada questão. A obsessão de Dostoiévski pelas "questões malditas", como a existência de Deus e da imortalidade, conjugada com a criação de personagens fortes, atormentados pela dúvida e pela descrença (como já foi assinalado no capítulo anterior, Mochulsky ressalta que Ivan é responsável por uma das mais consistentes

\footnotetext{
${ }^{140}$ FRANK, Op. Cit., 2008, p. 230.

${ }^{141}$ Idem, p. 231.
} 
defesas do ateísmo já escritas) abalaram aos olhos dos contemporâneos e de alguns estudiosos do romancista russo a genuinidade da "opção" pela fé apregoada pelo grande escritor. Alguns biógrafos, diferentemente de Joseph Frank, localizaram nessa indefinição entre a crença e a descrença a grande tragédia pessoal de Dostoiévski. Grossman, em sua biografia, reproduz uma declaração feita por Tolstói em 1883 sobre Dostoiévski protestando contra a elevação "to the level of prophet and Saint a man who died in the midst of a most heated inner struggle between good and evil. He is moving, interesting, but you cannot take a man who was all struggle, and set him up on a monument for the instruction of posterity"142.

Na biografia de Frank esta característica não se sobressai, pois o biógrafo traça o caminho do que ele denomina a "regeneração" das convicções de Dostoiévski após a prisão, ou seja, a conversão à fé religiosa da Igreja Ortodoxa sem se ater aos desvios. Apenas no segundo volume há uma afirmação de que seria "presunçoso nos dispormos a discutir aqui o grau de sinceridade das convicções religiosas de Dostoiévski»"143. Em entrevistas concedidas por Joseph Frank, este problema se torna mais evidente do que no texto escrito. No encontro com a professora Aurora Bernardini, à questão "Isso significa que Dostoiévski não estava absolutamente certo de suas crenças, que, não obstante, tinham de ser mantidas vivas?" Frank respondeu da seguinte forma: "Dostoiévski acreditava incondicionalmente em suas próprias ideias? Tudo o que podemos dizer é que ele conseguiu apresentar o que se opunha a elas com uma força artística impressionante"144. Na entrevista que o biógrafo nos concedeu recentemente, afirmou que “(...)He was always struggling with this problem of immortality and God, (...) on God existence or not(...) He was always fighting the problem, he never really

\footnotetext{
${ }^{142}$ GROSSMAN, Op. Cit., p 552.

${ }^{143}$ FRANK, Op. Cit., 2008, p. 230.

${ }^{144}$ BERNARDINI, Aurora Fornoni. "O Senhor Dostoiévski”. Folha de São Paulo Mais!, São Paulo, 13 jan. 2008, p. 7.
} 
made up his mind about any answer, you can't find any answer on his own personal writing, but sometimes in his writing for the public He affirms the existence of God(...) It's one of the problems of his work which I don't think that has ever been solved"145.

O segundo problema é determinar como este escritor controverso que, como apontou João Alexandre Barbosa, emergiu da obra de Frank como "um homem de meiaidade convulsionado por direções ideológicas contraditórias, buscando encontrar sempre um ancoradouro numa religiosidade exacerbada para onde ele fazia confluir uma crença também exaltada nos valores tradicionais do povo" 146 enfrentou a questão da autoria em sua obra de arte, principalmente no conjunto dos grandes romances que engloba de Crime e Castigo aos Irmãos Karamázov.

É importante ter em mente que Joseph Frank é um crítico de Mikhail Bakhtin, o autor do célebre estudo Problemas da Poética de Dostoiévski. Assim, tanto nos volumes da biografia, quanto com mais detalhes no artigo “As Vozes de Mikhail Bakhtin”, Frank expressa a sua discordância da teoria desenvolvida pelo crítico soviético na sua obra clássica. Neste artigo, Frank chama a atenção para o fato de Bakhtin ter buscado se contrapor ao "caminho de monologização filosófica" trilhado por muitos estudiosos que tenderam a localizar nas personagens do escritor russo as ideias do próprio Dostoiévski. Bakhtin, por sua vez, se concentra na nova atitude que pode ser divisada em Dostoiévski no que diz respeito ao autor com relação à personagem, que garante a independência dessa última e o seu inacabamento. Essa novidade está no cerne do romance-polifônico, cuja invenção teria sido, segundo Bakhtin, a grande contribuição do escritor russo para o mundo das letras.

\footnotetext{
${ }^{145}$ Entrevista concedida à autora desta dissertação em 10 de outubro de 2012, na residência de Joseph Frank, em Stanford, Palo Alto, Califórnia - EUA.

${ }^{146}$ BARBOSA, João Alexandre. Mistérios do Dicionário e outras crônicas literárias. São Paulo: Ateliê Editorial, 2004, p. 97.
} 
Frank não considera esta a melhor definição para as obras de Dostoiévski, pois afirma que “a expressão 'romance polifônico', no sentido forte sustentado por Bakhtin, não define em absoluto uma nova forma, porque o estudioso é incapaz de explicar como a independência absoluta da personagem ficcional pode combinar com a unidade de uma obra de arte" ${ }^{\text {147 }}$. Além disso, um segundo problema na visão de Frank se prefigura caso se aceite a interpretação de Bakhtin: a sugestão de que as obras do escritor russo são permeadas por um relativismo moral que embota aos olhos do leitor a real dimensão trágica da cruzada do escritor para sustentar os valores morais do cristianismo no seu tempo de avanço da secularização. Portanto, para o biógrafo de Dostoiévski a intromissão do autor é maior do que Bakhtin admitiu em sua obra, e por essa razão a melhor definição para as obras do escritor russo é "romance-tragédia", cunhada por Ivánov e não "romance polifônico", como afirmou Bakhtin.

A análise da leitura de Joseph Frank de um dos principais romances de Dostoiévski - Crime e Castigo - nos fornece uma amostra de como o biógrafo concebe a questão da autoria na obra do escritor russo. Quanto à técnica narrativa empregada em Crime e Castigo, Frank assinala que depois de um período de indecisão Dostoiévski optou por um narrador em terceira pessoa - onisciente - que, entretanto, encontra-se preso ao ponto de vista do protagonista e não se separa do herói (Raskólnikov). Frank ressalta que "essa técnica narrativa funde estreitamente o narrador com a consciência e o ponto de vista da personagem central, bem como com outras figuras importantes (embora, como Mikhail Bakhtin estava inclinado a afirmar, sem eliminá-lo inteiramente como uma perspectiva de controle)"148. Assim, para o biógrafo não é a consciência de Raskólnikov que estrutura o romance, pois existem episódios dos quais o herói não

\footnotetext{
${ }^{147}$ FRANK, Jospeh. Pelo Prisma Russo - Ensaios Sobre Literatura e Cultura. São Paulo: Editora da Universidade de São Paulo, 1992, p. 31.

148 FRANK, Joseph. Dostoiévski - Os Anos Milagrosos (1865 - 1871). São Paulo: Editora da Universidade de São Paulo, 2003, p. 138.
} 
participa e que no caso o que predomina é o ponto de vista do narrador, que é quem controla a trama. Há ainda, segundo Frank, a cronologia dos fatos que é de suma importância para o objetivo do autor no romance.

Uma vez concebido em consonância com as polêmicas da ordem do dia e o clima ideológico aquecido da Rússia de 1860, Crime e Castigo, que trata de um crime produto de uma orientação ideológica e suas consequências para o assassino foi, na visão de Frank, "organizado [através do desenvolvimento da ação] de maneira a guiar o leitor para uma percepção apropriada do significado do crime de Raskólnikov"149. Portanto, na visão do biógrafo, a intenção de Dostoiévski foi explicar as razões para o assassinato para exemplificar através da personagem por ele criada a ameaça contida nas doutrinas do niilismo russo. Quem procura o motivo é o próprio Raskólnikov e o autor se responsabiliza por fornecer as pistas que ao mesmo tempo ajudam e atrapalham o leitor a desvendar o mistério junto ao herói. As pistas corretas que, segundo Frank, foram plantadas desde o início da ação de forma calculada pelo autor encaminham o leitor para a descoberta final de Raskólnikov: que o seu crime foi motivado pelo seu egoísmo e pela necessidade de testar a sua força em consonância com as suas "novas" ideias. Nas palavras de Frank: "Assim, dentro da narrativa de Crime e Castigo está inserida uma ideia de como o romance deve ser lido, uma hermenêutica de sua interpretação, que é a parte integrante de seu tema anti-radical e expressa a crença na importância das ideias e em seu poder de influenciar o comportamento humano, crença que Dostoiévski manifestou muitas vezes." 150

Em linhas gerais, Frank afirma que ocorre de fato uma identificação entre o leitor e o ponto de vista de Raskólnikov durante a primeira parte do livro, que é quando

\footnotetext{
149 Idem, p. 145.
}

${ }^{150}$ Idem, p. 151. 
parece predominar a explicação altruística e humanitária para o assassinato (o herói como vítima da pobreza, almejando beneficiar sua família com os ganhos obtidos etc). Para Frank, porém, "Dostoiévski está longe de querer que esta motivação seja vista como exclusiva" ${ }^{\prime 151}$. O motivo real, ou o objetivo de verificar se ele era um Napoleão ou um piolho vai se descortinando mais tarde, em passagens como no encontro com Lújin, com Zamiótov, com Sônia quando ele verbaliza o seu desejo de poder, entre outras. É interessante atentar para uma observação de Joseph Frank referente a esse encontro entre Sônia e Raskólnikov, pois na visão do biógrafo "Em nenhum outro lugar talvez, chegamos mais perto da própria relação tortuosamente angustiada de Dostoiévski com a fé religiosa do que na mistura de temor involuntário e ceticismo autoconsciente com que Raskólnikov reage a Sônia" ${ }^{152}$.

Assim, na arena oposta à do grande crítico Mikhail Bakhtin, Joseph Frank constrói a sua interpretação da obra de Fiódor Dostoiévski respondendo de uma perspectiva diferente ao desafio da questão da autoria que a mesma coloca para os seus leitores. Quanto a Crime e Castigo em particular, Frank sustenta que a visão de mundo do narrador se sobressai e que a intenção do autor é conduzir o leitor por meio da ordem dos fatos englobados pela narrativa para a solução do mistério da motivação do crime.

A leitura proposta por Joseph Frank inevitavelmente retira da obra de Dostoiévski muito do seu potencial de inovação identificado por Bakhtin. A partir da maneira como ele conduz a sua análise, o leitor da biografia é acometido pela impressão de estar lendo uma crítica de uma "história moderna de detetive ou um thriller de aventura criminosa" mas, "evidentemente muito mais profundo e mais complexo em

\footnotetext{
151 Idem, p. 155.
}

${ }^{152}$ Idem, p. 185. 
termos morais" ${ }^{253}$. Esse caminho, no entanto, pode frustrar o leitor que desconfia estar diante de um texto elaborado de forma muito diferente dos demais romances do século XIX.

O leitor que não se contentará com a análise de Joseph Frank é aquele que ao ler Crime e Castigo não percebeu com clareza onde se encontrava o corte separando o discurso do narrador do discurso de Raskólnikov. É o mesmo que embarcou no tempo da narrativa no mesmo compasso do tempo emocional de Raskólnikov, e que percebeu os demais acontecimentos juntamente com o herói, e não apesar dele (com exceção do momento em que o foco do narrador se atém a Lújin e a Svidrigáilov). É aquele que se sentiu diante do misterioso e do inesperado a cada página percorrida, sem ter sido sequer capaz de palpitar sobre a próxima ação de Raskólnikov, mesmo sem ter-se separado desse último por um momento sequer. Raskólnikov, o companheiro de todas as horas não deixou de ser um enigma perigoso para esse leitor até o fim do romance, e nenhuma das suas ações pode ser minimamente prevista, imaginada, por mais que analistas como Frank defendam a existência de um narrador próximo do autor que sugere ao leitor um caminho para a compreensão da obra. No final do romance, quando o epílogo surge como uma peça que desorganiza totalmente o quebra-cabeça montado por Dostoiévski na cabeça do leitor, exatamente por ser o momento que a voz do narrador se sobressai à de Raskólnikov, esse mesmo leitor se sentirá órfão por ter sido separado à força do herói que o conduziu pelas muitas páginas dessa obra prima. $\mathrm{O}$ leitor que teve esta experiência de leitura não consegue se convencer totalmente de que a análise sugerida por Joseph Frank é a melhor possível para a compreensão de Crime $e$ Castigo.

\footnotetext{
${ }^{153}$ Idem, p. 150.
} 
A confusão do leitor da biografia escrita por Joseph Frank, por sua vez, se agrava diante de uma passagem como a citada anteriormente, que sugere que Dostoiévski revela a si próprio no trecho em que Raskólnikov lê o Evangelho junto à Sônia. O primeiro aspecto que chama a atenção é o fato desta passagem evidenciar a relação "tortuosa" de Dostoiévski com a fé, qualidade dessa relação que não se sobressai na análise de Frank sobre a questão, pois como já foi assinalado, o biógrafo defende que apesar de certa oscilação, após a prisão a fé do escritor havia se tornado inabalável. O segundo aspecto digno de nota é a maneira como Frank confunde o autor com a personagem por ele criada, sugerindo uma relação de simbiose que também será apontada algumas vezes em outros romances com outras personagens. Evidentemente Frank é um crítico sério que não recorre à simplista solução biográfica de acreditar que um escritor está presente, enquanto indivíduo, nas suas obras ficcionais. Mas é como se em uma passagem ou outra o autor não resistisse a uma comparação para ilustrar alguns trechos do seu texto e criar um efeito poético.

Por exemplo, na análise de $O$ Pequeno herói, texto que Dostoiévski escreveu preso na Fortaleza de Pedro e Paulo sobre um rapaz apaixonado que resolve encobrir o romance da sua amada com outro homem, Frank escreveu: "Em outras palavras, seu amor consiste em realizar um ato de autossacrifício para ajudar uma alma sofredora e em ser capaz de manter um segredo. Será que Dostoiévski não estava se vendo exatamente nessa situação? Afinal, ele havia se sacrificado pela libertação do povo russo sofredor e ainda estava lutando para manter o segredo da conspiração diante das autoridades" $" 154$. Há outros exemplos dessa correspondência nos grandes romances e Frank enxerga, por exemplo, características do próprio Dostoiévski em personagens

\footnotetext{
${ }^{154}$ FRANK, Op. Cit., , 2008, p. 62.
} 
como o príncipe Míchkin e Aleksiei de $O$ Jogador (Frank não considera este último um romance autobiográfico, mas uma "racionalização para si mesmo" do vício pelo jogo).

É interessante perceber que essa relação de simbiose não se restringe na biografia à maneira como Frank descreve a postura de Dostoiévski diante de alguns de seus personagens, mas curiosamente às vezes é perceptível entre o próprio biógrafo e sujeito biografado, entre Joseph Frank e Dostoiévski. Uma vez que Joseph Frank se lança ao desafio de escrever a biografia do grande romancista russo com o ardor de um escritor que redige a obra de uma vida (a da sua vida), é compreensível que o biógrafo tenha se deixado levar em alguns momentos pelo já mencionado processo de identificação com o sujeito biografado. Nas palavras de Schnaiderman, "tamanho foi seu empenho pessoal que, no prefácio ao terceiro volume, [Joseph Frank] chega a chamar a sua obra de autobiografia, e não creio que se trate de um lapso de tradução"155. É interessante atentar para o fato que Schnaiderman estava enganado e que a opção pela palavra "autobiografia" se tratou de um lapso de tradução. Este lapso do tradutor, no entanto, indica um interessante caminho de reflexão sobre o envolvimento de Joseph Frank com o sujeito biografado.

O mergulho vertiginoso na personalidade de um homem e de tudo que o envolve - sua obra, seu tempo - aproxima o cuidadoso e equilibrado biógrafo do destemperado e convulsivo biografado, e a "vitalidade de um gato" 156 que o primeiro identifica no escritor russo também é algo reconhecível nele próprio. Frank perdeu o pai muito cedo e sua infância foi marcada pelo terror provocado por um problema de fala (stammer, que o tornou inapto para o serviço militar) e pelo isolamento e introspecção alimentada pela paixão pelos livros. Assim como Dostoiévski em sua infância, Frank não teve muita

\footnotetext{
${ }^{155}$ SCHNAIDERMAN, Boris. "O Manto e o Profeta”. O Estado de S. Paulo. Domingo, 23 mar. 2008, p. D9.

${ }^{156}$ FRANK, Op. Cit., 2002, p. 499.
} 
interação social em seus primeiros anos, e passou a maior parte do tempo na companhia das obras primas da literatura. Outro dado da vida de Frank que o aproxima do seu biografado foram os constantes problemas financeiros que o acompanharam ao longo da sua aventura profissional.

Frank não teve um diploma de bacharel e a sua trajetória rumo ao mainstream da crítica literária foi mais do que singular. Ele frequentou aulas na New York University, mas as mortes seguidas do seu padrasto e da sua mãe acarretaram problemas financeiros que o obrigaram a mudar de estado. Em Wisconsin, Frank pode novamente frequentar a universidade, pois na University of Wisconsin havia um acadêmico simpático aos estudantes judeus desprovidos de recursos para os estudos, mas ele novamente não concluiu o curso, pois um emprego editorial em Washington, no Bureau of National Affairs, falou mais alto para um jovem com pouco dinheiro no bolso. $\mathrm{Na}$ década de 1940 ele publicou ensaios de crítica literária em revistas especializadas, dentre os quais o já mencionado "Spatial Form in Modern Literature", que sedimentou a sua carreira como crítico literário. Na década de 1950 ele foi estudar em Paris com uma bolsa Fulbright e ao retornar aos EUA foi aceito pelo Committee on Social Thought at the University of Chicago, onde foi titulado PhD. Frank lecionou na University of Minnesota and Rutgers, Princeton e em Stanford. Não bastasse esse percurso pouco convencional do início da atividade profissional, Frank ainda conseguiu na meia idade mudar todo o curso da sua carreira acadêmica, aventurar-se em um novo e complexo idioma, aprender a história cultural da Rússia e se dedicar a um empreendimento ambicioso, tornando-se ao fim da tarefa um dos maiores especialistas em Dostoiévski na criteriosa academia norte-americana. Alguém com tal biografia também tem entre as qualidades a mesma "vitalidade de um gato" do romancista russo. 
Ao reconhecermos a existência deste processo de identificação, ainda que este tenha aparecido na biografia da autoria de Frank de maneira sutil, sem comprometer a qualidade da obra e o compromisso do biógrafo com as fontes documentais, operamos com a hipótese segundo a qual houve uma leve projeção do biógrafo na vida narrada por ele. Como consequência, em algumas passagens da biografia delineia-se o que, dentro dessa chave de interpretação, é a resistência de Frank para apontar as facetas mais controversas da personalidade de Dostoiévski. Assim, o processo de identificação somado ao fascínio de Frank por Dostoiévski dificultou a abordagem independente de temas espinhosos na biografia que, em certa medida, poderiam ofuscar o brilho da estrela de Dostoiévski como, por exemplo, a xenofobia, o chauvinismo, o antissemitismo e as ideias políticas do autor de maneira geral.

Unanimidade literária, um dos maiores escritores da literatura universal é também um pensador controverso, capaz de deixar boquiabertos os seus mais incondicionais admiradores, com o conservadorismo e o preconceito de algumas das suas posições políticas, expressas principalmente por meio da sua atuação na imprensa russa da época. Alguns exemplos dessas posições desconcertantes podem ser retirados das páginas de O Diário de um Escritor, uma publicação criada por Dostoiévski na qual este discutia os acontecimentos da ordem do dia e expressava as suas ideias políticas e literárias com toda a liberdade. O Diário de um Escritor surge como uma coluna no jornal $O$ Cidadão (1873) e mais tarde se torna uma publicação independente de total responsabilidade de Dostoiévski - a mais lida entre todas aquelas semelhantes que apareceram em 1876-77 e em 1881.

Além de $O$ Diário de um Escritor, Dostoiévski também se dedicou às revistas $O$ Tempo e A Época, como mencionado. Frank analisa com boa vontade essa atuação jornalística, uma vez que em sua opinião "Dostoiévski nunca traçava uma linha rígida 
entre suas obras puramente criativas e o jornalismo" ${ }^{157}$, e vislumbra sinais de uma orientação progressista supostamente seguida por esses periódicos. No seu exame sobre os motivos da pouca acolhida que $A$ Época recebeu dos leitores, Frank afirma que "grande parte da atração da antiga revista [O Tempo] fora a combinação que conseguira de uma posição sociopolítica liberal ou moderadamente radical com uma ênfase eslavófila que apelava ao sentimento patriótico e nacionalista. (...) o fechamento do Tempo lhes mostrara o quanto era perigoso imprimir à revista uma inclinação grande demais para a esquerda [grifo meu], com o risco de incorrer no desagrado das autoridades" ${ }^{\prime 158}$. Frank chega a atribuir uma tendência esquerdista pelo menos a esse primeiro momento jornalístico vivido por Dostoiévski. Ele não encontra meios, porém, de sustentar essa posição quando analisa $O$ Diário de um Escritor, no qual Dostoiévski exprimiu diretamente muitas das suas polêmicas ideias.

Na análise de $O$ Diário, Frank mostra-se algumas vezes desconcertado com o Dostoiévski polemista. No prefácio do quinto volume da biografia Dostoiévski, o biografo chega a afirmar que as pretensas (grifo meu) ideias políticas de Dostoiévski “pareciam tão excêntricas que dificilmente alguém as levaria a sério. Na verdade, é minha opinião que se quisermos fazer-lhe justiça como romancista, devemos esquecêlas" ${ }^{, 159}$. No último volume, esse mesmo apelo vem à tona diversas vezes, por exemplo, quando Frank se debruça sobre o último texto que foi redigido pelo romancista no seu Diário (uma glorificação da aventura malsucedida da Rússia na sua tentativa de conquistar o oásis de Geok Tape e a defesa de uma "missão civilizatória" na Ásia) e conclui que "infelizmente, o que Dostoiévski tem a dizer no caso não figura entre suas elocuções mais impressionantes e atraentes. Mas dever-se-ia ler suas últimas palavras

\footnotetext{
${ }^{157}$ FRANK, Op. Cit., 2007, p. 260.

${ }^{158}$ FRANK, Op. Cit., 2002, p. 480.

${ }^{159}$ FRANK, Op. Cit., 2007, p. 14.
} 
impressas sempre com a mente concentrada em suas grandes realizações no campo da criação - as obras-primas - que superam em importância e escondem suas ilusões e autoenganos sociopolíticos"160 . Por conseguinte, a proposta que o biógrafo faz ao leitor é sintomática de um receio de que essa faceta da complexa personalidade do escritor russo macule a sua gloriosa imagem de gigante das letras.

Não podendo passar ao largo dessa questão, Frank se viu forçado a discutir os textos nos quais essas ideias políticas encontravam-se expressas. Muitas vezes o biógrafo tentou resgatar Dostoiévski do antro do conservadorismo político afirmando em diversas passagens que no pensamento do escritor misturava-se "uma defesa das estruturas sociais mais reacionárias em nome dos princípios mais liberais" ${ }^{\text {161 }}$, portanto que o apoio irrestrito ao czarismo convivia com um anseio por mudanças estruturais, porém por uma via pacífica e não revolucionária. Assim, a simpatia pelas reformas que Dostoiévski nutria serviu para o biógrafo corroborar em certa medida a opinião do romancista sobre si segundo a qual, "longe de ser partidário da reação, [ele] ocupava uma certa posição mediana, como defensor entusiasta de todas as inovações liberais

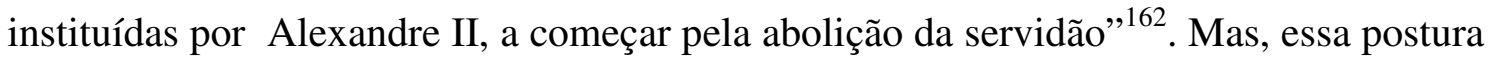
de abrandar certas posições políticas de Dostoiévski e de preferir enxergar uma possível "divisão interna dentro dele mesmo"163 no tocante às convicções mais espinhosas, como por exemplo o antissemitismo, não impediu que em algumas passagens um desapontamento sincero escapasse da sua pena de biógrafo.

No caso do antissemitismo, por exemplo, Frank rotula de "repulsivo" o ódio incontido e injustificável que o escritor russo nutria pelos judeus, contra quem no

\footnotetext{
${ }^{160}$ Idem, p. 899- 900.

${ }^{161}$ Idem, p. 893.

${ }^{162}$ FRANK, Joseph,Dostoiévski: Os Anos Milagrosos 1865-1871. São Paulo: Edusp, 2003, p. 333.

${ }^{163}$ FRANK, Op. Cit., 2007, p. 393.
} 
Diário "fez as acusações mais terríveis, chamando-os de exploradores impiedosos da miséria alheia, induzidos pela sede insaciável do ganho, e culpando-os de desenvolverem sua influência internacional contra os interesses do Estado russo" ${ }^{\text {"164 }}$. Já no caso do nacionalismo xenófobo e do imperialismo tacanho de Dostoiévski, desdobramentos do seu amor pela pátria, Frank também lamenta os excessos do escritor que podem ser localizados, por exemplo, no seu último texto (já mencionado) sobre as pretensões imperialistas da Rússia na Ásia, ou na sua defesa da guerra Russo-Turca (1877-78) e a justificação em elevados princípios morais e religiosos do envolvimento do seu país no conflito balcânico. Para Frank, "as elucubrações de Dostoiévski sobre a Questão Balcânica estão entre suas páginas mais entediantes e deploráveis, e apenas repetem os mesmos autopanegíricos nacionalistas em contextos diferentes"165.

Entretanto, quanto à obsessão de Dostoiévski pelo destino da Rússia, Frank tenta procurar nas páginas do escritor resquícios de uma possível consciência da parte deste último acerca da irrealidade de certas convicções da grandeza, retidão moral e espiritual da sua pátria. Ele localiza esses resquícios nos textos que evocavam com alguma regularidade a figura literária de Don Quixote, que inspirou Dostoiévski a indagar seus leitores se estes nunca acalentaram um sonho, uma ideia, que poderia perfeitamente se tratar de uma mentira e que para se evitar que assim o fosse não se apressaram em inventar um novo sonho, uma nova mentira, apenas para resolver de uma vez por todas a dúvida anterior. Para Frank, "se isso pode ser verdade com relação aos leitores de Dostoiévski, pode sê-lo igualmente para ele próprio. É impossível deixar de indagar se aqui, nessas reflexões tristemente melancólicas, Dostoiévski também não estava dando voz a alguma incerteza interior sobre suas mais caras convicções relativas ao povo russo e ao glorioso papel que ele deveria representar, no futuro, na história mundial. Não teria

\footnotetext{
${ }^{164}$ Idem, p. 381.

${ }^{165}$ Idem, p. 354.
} 
ele, que entendia tão bem a capacidade do homem de autoiludir-se, ter sentido também algumas vezes que suas grandiosas previsões eram um meio de resgatar-se do desespero quando contemplava sua Dulcinéia russa?"166.

Apesar dessa bela construção argumentativa do biógrafo, podemos duvidar da propriedade da sua conclusão. É pouco provável que o escritor de fato desconfiasse da sua convicção mais arraigada, cultivada por toda a vida. No emaranhado das ideias nacionalistas defendidas por Dostoiévski, a visão positiva e esperançosa do futuro da sociedade russa em oposição à visão pessimista do destino da Europa Ocidental foi obsessivamente reafirmada ao longo da trajetória do escritor.

A impressão que acomete o leitor é que Frank busca justificar certas posturas de Dostoiévski, ou mesmo convencer o leitor do quanto os consensos historicamente construídos sobre algumas facetas do escritor como, por exemplo, o seu conservadorismo político, são equivocados. Outro consenso que Frank busca combater é o que se estabeleceu a respeito da personalidade difícil, desequilibrada e controversa do romancista russo. A partir da análise de Sigmund Freud do "caso" Dostoiévski, a personalidade do escritor foi denominada em termos psicanalíticos como "sadomasoquista". Frank discorda em absoluto das opiniões de Freud sobre Dostoiévski e busca combater as ideias do pai da psicanálise desenvolvidas no ensaio Dostoiévski e o Parricídio.

Neste ensaio Freud se debruçou sobre a neurose de Dostoiévski, o que no seu ponto de vista conjuntamente à vida emocional intensa, à disposição sadomasoquista/ criminosa e ao enorme talento explicaria a complexa personalidade do célebre escritor russo. Para Freud, a epilepsia que acompanhou Dostoiévski por toda a vida não era

\footnotetext{
${ }^{166}$ Idem, p. 358.
} 
orgânica, ou seja, uma doença cerebral, mas "afetiva", portanto um sintoma da neurose do escritor que deveria ser corretamente classificada como histeria grave (histeroepilepsia). A escassez de informações impede que Freud avance para muito além das suposições, mas na sua visão o mais provável é que as crises remontem à primeira infância de Dostoiévski, apesar de ainda não se tratarem de crises epiléticas propriamente ditas. A manifestação definitiva da doença teria ocorrido logo depois que Dostoiévski tomou conhecimento do assassinato do pai pelos servos da propriedade da família. O assassinato ocorreu quando o escritor tinha dezoito anos e, para Freud, "somos tentados a ver nesse acontecimento o trauma mais severo e a encarar a reação de Dostoiévski a ele como o ponto decisivo de sua neurose" ${ }^{\text {"167. }}$.

Freud afirma que as primeiras manifestações da doença consistiam na sensação de morte, a ponto de ainda menino Dostoiévski adquirir o hábito de escrever bilhetes antes de dormir anunciado o seu medo de cair em um sono semelhante à morte e a instrução para que a família adiasse o seu enterro por um período de cinco dias. Esse medo infundado da morte seria o resultado de uma identificação com alguém morto ou com alguém a quem se deseja a morte, e adquiriria o valor de punição. No campo da teoria psicanalítica, essa pessoa que o menino deseja ver morta é o pai, e o desejo é precedido pela identificação com a instância parental após a dissolução do complexo de Édipo, mas no caso de Dostoiévski a sua suposta bissexualidade também entrou em jogo obstruindo a resolução normal do complexo e abriu espaço para o desenvolvimento da neurose. Para Freud, indícios dessa disposição à homossexualidade podem ser extraídos da importância que as amizades masculinas desempenharam na vida do escritor, assim como na sua atitude benevolente para com os seus rivais no amor e por passagens que figuram em seus romances.

167 FREUD, Sigmund, "Dostoievski e o Parricídio" IN: Obras Psicológicas Completas. Rio de Janeiro: Imago Editora, Vol. XXI, p. 210. 
Quando o menino apresenta esse componente homossexual, o ódio pelo pai convive com o amor por este e o desejo de colocar-se no lugar da mãe. A ameaça da castração se torna mais problemática porque o menino entende que deve se submeter a ela para ser amado pelo pai como mulher, por isso tanto o ódio pelo pai quanto o amor pelo pai experimentam repressão. A intensificação patogênica resulta do temor à atitude feminina e não do medo direto da castração. Outra consequência da repressão do ódio pelo pai é a formação do superego. No caso de Dostoiévski, cujo pai era violento e cruel, o superego adquiriu essas características e se tornou sádico na relação com o ego, que por sua vez se tornou masoquista e desenvolveu uma enorme necessidade de punição. Nas palavras de Freud: "a relação entre o indivíduo e o seu objeto paterno, embora retendo o seu conteúdo, foi transformada numa nova relação entre o ego e o superego - um novo cenário num novo palco"168. Tendendo a desaparecer com o tempo, no caso de Dostoiévski a brutalidade do seu pai fez com que o ódio e o desejo de morte contra a figura paterna se mantivessem, assim como o desejo de punição interiorizado pelo ego. Quando ocorre o assassinato do pai e finalmente a sua fantasia se materializa, e a epilepsia surge como uma identificação com o pai morto e como uma terrível punição.

Para Freud, apenas a comprovação de que as crises epiléticas de Dostoiévski teriam cessado durante os seus anos de prisioneiro na Sibéria permitiria que a sua análise da neurose do escritor saísse de um plano meramente especulativo. Na ausência dessas provas, Freud se deteve na atitude inabalável de Dostoiévski diante do castigo injusto que lhe foi infligido pelo Czar para reforçar a sua conclusão de que havia uma forte necessidade de punição por parte da economia mental do autor de Os Irmãos Karamázov. Outro indício dessa necessidade Freud a identifica na mania de jogo do 
escritor, também um método de autopunição. O hábito de quebrar repetidamente a promessa de nunca mais jogar feita à esposa e de só retornar das mesas de jogo com as mãos abanando e na mais profunda miséria proporcionava-lhe prazer porque "podia então censurar-se e humilhar-se diante dela, convidá-la a desprezá-lo (...); quando havia assim aliviado a sua consciência, recomeçava tudo no dia seguinte."169. Freud observa que a jovem esposa acabou por acostumar-se a esse ciclo infernal, pois pode perceber que a produtividade de Dostoiévski como escritor aumentava quando ele se deparava com o seu total colapso financeiro. Ainda segundo Freud, Ana não conseguiu compreender a conexão entre os fatos, mas "quando o sentimento de culpa dele ficava satisfeito pelos castigos que se haviam infligido, a inibição incidente sobre seu trabalho se tornava menos grave e ele se permitia dar alguns passos ao longo da estrada do sucesso." ${ }^{170}$. Uma vez desvendada a origem da neurose de Dostoiévski - a sua necessidade de (auto) punição -, esta não sairia de cena durante toda a vida do escritor e consistiria na explicação para as suas atitudes diante das outras esferas da vida nas quais a relação paterna serviria de medida: a crença em Deus e a submissão à autoridade do Estado.

O ensaio de Freud culmina no seu breve comentário sobre a obra Os Irmãos Karamázov, para quem não é casual que o escritor tenha atribuído a sua mesma doença ao assassino de Fiódor Pavlovich (o pai). Segundo Freud,

A simpatia de Dostoiévski pelo criminoso é, de fato, ilimitada (...). Um criminoso, para ele, é quase um redentor, que tomou sobre si próprio a culpa que, em outro caso, deveria ter sido carregada pelos outros. Não há mais necessidade de que alguém mate, visto que ele já matou, e há que ser-lhe grato; não fosse

\footnotetext{
169 Idem, p. 220.

${ }^{170}$ Idem, p. 220.
} 
ele, ver-nos-íamos obrigados a matar. Isso não é apenas piedade bondosa, mas uma identificação com base em impulsos assassinos semelhantes - na realidade, um narcisismo ligeiramente deslocado. (...) Não há dúvida de que essa simpatia por identificação constitui fator decisivo na determinação da escolha de material de Dostoiévski. Ele tratou primeiramente do criminoso comum (cujos motivos são egoístas) e do criminoso político e religioso, sendo somente ao fim de sua vida que retornou ao criminoso primevo, ao parricida, e utilizou-o, numa obra de arte, para efetuar sua confissão ${ }^{171}$.

Intitulada "O Caso Dostoiévski, segundo Freud", a resposta de Frank foi escrita primeiramente na forma de artigo, sendo posteriormente incluída como apêndice em Dostoiévski - As Sementes da Revolta (1821-1849), o primeiro volume da biografia. O mergulho no material disponível sobre a vida do escritor fez com que Frank se deparasse com "perturbadoras discrepâncias" entre as informações fornecidas por esse material e os fatos nos quais Freud se apoiou. Pergunta ele: "Até que ponto se pode confiar em Freud no plano puramente factual, na medida em que se possa determiná-lo? Quais são suas fontes e como ele as utilizou?"172.

O primeiro aspecto da análise de Freud que Frank critica é a opinião segundo a qual a natureza da epilepsia de Dostoiévski era psíquica e não orgânica. Para Frank, a morte em 1878 do filho de três anos de idade de Dostoiévski em decorrência de um grave ataque epilético figuraria como prova de que a doença da criança teria sido herdada do pai, portanto consistiria em uma doença cerebral, de origem "orgânica". Frank aproveita essa evidência para ironizar uma delicada opinião que Freud sustentou durante toda sua vida e que o transformou, na visão do pesquisador norte-americano, em 
um "impertinente lamarckiano, que continuava a crer na hereditariedade das características adquiridas muito depois de essa tese ter sido abandonada"173.

O segundo ponto que Frank contesta é a atitude feminina de homossexualidade latente que Freud apontou em Dostoiévski. Frank afirma que as amizades masculinas intensas de Dostoiévski foram "muito breves e nada típicas". Tanto que, prossegue Frank de maneira provocativa, "não há nenhuma amizade masculina na vida de Dostoiévski comparável em duração e importância emocional com a amizade de Freud com Wilhelm Fleiss e Joseph Breuer, por exemplo"174. Frank afirma que as relações com as mulheres foram mais importantes durante a vida de Dostoiévski, e que a sua benevolência para com um rival no amor consistiu em um caso isolado que ocorreu durante o seu exílio na Sibéria, e que não pode ser tomado como um dado significativo da sua biografia. Por fim, esses comportamentos aparecem nos seus romances porque se tratam de um clichê literário da época.

O terceiro aspecto que é alvo de críticas é a afirmação de que o pai de Dostoiévski era um homem violento. Frank se apoia numa descrição do irmão mais novo do escritor, para quem o pai era um homem despótico, temperamental, bruto e irascível, mas que nunca infligira castigos corporais aos seus filhos e que desaprovava a violência física. Outro aspecto que Frank encara como insustentável é a demonstração de que a repercussão da violência paterna sobre a constituição bissexual de Dostoiévski levou ao aparecimento de sintomas da epilepsia já durante a infância que iriam culminar na erupção da doença após o assassinato. Para o biógrafo, estes sintomas que assumiam a forma de uma identificação com uma pessoa morta não podem ser relacionados à infância de Dostoiévski, pois nenhuma fonte confirma esse fato. Segundo Frank, as 
crises, que consistiam em um grave distúrbio nervoso, surgiram no período de 18461847 e os bilhetes com as instruções para o enterro datam de meados ou fins da década de 40, portanto de quando Dostoiévski não era mais criança.

Por fim, o pilar sobre o qual se ergue a explicação para o "caso" Dostoiévski é também demolido pelo pesquisador. Segundo Freud, o primeiro ataque da epilepsia ocorreu quando o escritor recebeu a notícia do assassinato do pai exprimindo uma necessidade de autopunição. A comprovação da tese dependeria da certeza de que os ataques cessaram durante os anos de punição na Sibéria. Porém, nas palavras de Frank, "Ora, é lamentavelmente embaraçoso para a tese de Freud que todos os testemunhos, exceto a versão tradicional da família, indiquem que a epilepsia de Dostoiévski começou na Sibéria; a única prova possível do argumento de Freud vem a ser, portanto, uma contraprova" ${ }^{175}$. Dentre esses testemunhos, destacam-se as cartas escritas pelo próprio Dostoiévski quando da sua libertação do presídio, que narram o aparecimento da sua doença apenas um ou dois anos antes. Freud, por sua vez, leu com desconfiança essas cartas afirmando que é necessário se colocar em dúvida as memórias autobiográficas de neuróticos. Mas, em um aspecto Frank concorda com Freud: de fato a saúde geral do escritor melhorou durante os seus anos na Sibéria, apesar do surgimento das crises epiléticas.

Assim, Frank descarta a neurose na constituição psíquica de Dostoiévski em uma atitude que ilustra o quanto as "definições sobre saúde, normalidade e sofrimento psíquico estão longe de ser imunes a conflitos: são aspectos de um embate social a respeito do que entendemos por "vida mutilada", ${ }^{176}$. Portanto, no nosso ponto de vista, o desconforto com o qual se costuma enfrentar os assuntos relacionados à saúde psíquica 
e mental explica a reserva de Frank com relação à interpretação psicanalítica do "caso" Dostoiévski, assim como a justificável desconfiança das interpretações psicanalíticas realizadas "a posteriori”. Evidentemente que a apreciação de Frank, fruto de uma pesquisa cuidadosa, aproxima-se mais do que a de Freud da correção factual. Entretanto, certos aspectos da análise de Freud como, por exemplo, o desvendar da personalidade masoquista do escritor, apresentam caminhos interessantes para se refletir sobre a complexa individualidade de Dostoiévski.

O tema da loucura é recorrente no universo dostoievskiano. Muitos dos contemporâneos do escritor concluíram que a suposta loucura de Dostoiévski explicaria a sua fixação pelos tipos "desajustados" que povoam os seus romances. As acusações ganharam força principalmente após a conclusão de Os Demônios. Frank recupera a afirmação de Soloviev, que lança luz sobre esse fato: "O autor de Crime e Castigo e Recordação da Casa dos Mortos era chamado de louco, maníaco, renegado, traidor, chegou-se a convidar o público a visitar o espetáculo na Academia de Artes, para olhar o retrato de Dostoiévski pintado por Perov, a primeira prova de que ele estava louco, cujo lugar era uma casa de débeis mentais" ${ }^{\text {177 }}$. No entanto, a acusação de que o escritor nutria uma fixação anormal pela loucura perseguiu Dostoiévski desde o início da sua carreira literária. O lançamento de $O$ Duplo, seu segundo trabalho, é acompanhado pela desaprovação de grande parte dos críticos à matéria abordada na obra. Esse foi o caso de Bielínski, que entendeu que "o que Dostoiévski fez foi meramente descrever um caso de paranoia e esgotamento mental sem nenhum outro significado além de um caso clínico. Esse parecer determinou o padrão de interpretação das primeiras obras de Dostoiévski (e de grande parte dos trabalhos posteriores) que prevaleceu na crítica russa até o final

\footnotetext{
${ }^{177}$ FRANK, Op. Cit., 2007, p 98.
} 
do século XIX"178. Assim, a suposta loucura de Dostoiévski foi alardeada pelos seus contemporâneos e, consequentemente, investigada pelos seus biógrafos. Vimos, por sua vez, que a maior parte destes, assim como Joseph Frank, descarta a hipótese da loucura do escritor.

É fato, por sua vez, que esses biógrafos não atenuam os indícios do "gênio" difícil de Dostoiévski e os traços da sua personalidade masoquista, segundo a definição de Freud. Já Joseph Frank, diferentemente dos demais, se recusa a reconhecer certas incongruências do escritor, o que é muito notório na análise destinada ao vício pelo jogo de Dostoiévski. Frank, ao contrário dos demais biógrafos, corrobora a própria explicação que Dostoiévski forneceu para o motivo do seu vício, racionalizando dessa forma um dado da biografia do romancista sempre explicado com base em análises psicológicas. Concomitantemente, ele procura minimizar a importância desse fato, afirmando que os biógrafos que o antecederam supervalorizaram equivocadamente o vício de Dostoiévski, que teve, na verdade, uma importância circunstancial e diminuta na sua trajetória de vida.

Assim, segundo o biógrafo, alguns indícios permitem-no combater essa supervalorização do vício pelo jogo recorrente na tradição biográfica sobre a vida de Dostoiévski: o fato dele apenas esporadicamente ter-se dirigido aos cassinos, e de nunca ter recorrido a eles nas fases de segurança financeira e emocional. É por essa razão que, segundo Frank, "Dostoiévski não foi um jogador congênito e incuravelmente patológico (...) mas apenas um jogador repetitivo, sujeito a episódios recorrentes e capaz de abstenção na maior parte da vida"179. A explicação para esse vício, ainda segundo o biógrafo, "foi sempre a esperança banal de ganhar bastante dinheiro para tirá-lo de

\footnotetext{
${ }^{178}$ FRANK, Op. Cit., 2008. 2. ed., p. 395.

${ }^{179}$ FRANK, Op. Cit., 2002. p 360.
} 
situações difíceis; e, mesmo que usualmente tenha acabado perdendo cada centavo, não se pode dizer que seu objetivo fosse totalmente irracional. Ganhou muitas vezes grandes somas, que depois conseguiu perder imediatamente ou após alguns dias - exatamente como aconteceu em Wiesbaden- porque nunca parou a tempo" ${ }^{\text {"180 }}$. Ao longo desse parágrafo o biógrafo é impelido a reconhecer que não se pode negar que o vício satisfazia "alguma profunda necessidade psíquica do romancista"181, e que, por conseguinte, não poderia ser explicado apenas com base nas dificuldades financeiras do escritor. Mas, para Frank, o vício se tornou um aspecto "dominante" em Dostoiévski apenas em momentos especiais, o que o retirava do grupo dos jogadores "patológicos".

Frank utiliza ainda como argumento favorável à sua tese o desaparecimento do vício de Dostoiévski após o segundo trimestre do ano 1871, ano no qual este fez suas últimas apostas nos cassinos, e depois nunca mais se aproximou de uma mesa de jogo. Ele inclusive critica o fato de sempre ter-se dado atenção em demasia ao vício e quase nenhuma a superação desse vício. Alguns autores que abordaram o tema, como Edward Carr, tenderam a atribuir o abandono do vício de Dostoiévski ao fechamento dos cassinos na Alemanha, portanto nas quatro outras viagens que o escritor fez ao país por motivos de saúde, ele se viu impossibilitado de jogar exatamente porque essa atividade havia sido proibida. A esta razão alguns biógrafos acrescentam outros motivos como a idade avançada e a fragilidade da saúde do escritor, que nessa época não era mais o jovem Dostoiévski que se precipitava para os salões de jogos na primeira oportunidade.

Joseph Frank, por sua vez, considera insuficiente a explicação do fechamento dos cassinos e atribui ao escritor o mérito pelo abandono do vício de jogar. Este dado, ainda segundo Frank, desponta como uma prova cabal contrária às conclusões de Freud,

\footnotetext{
${ }^{180}$ Idem, p. 360.
}

${ }^{181}$ Idem, p. 360. 
pois como ele afirma "cabe supor, portanto, que Dostoiévski dominou o desejo de jogar - um desejo que, na opinião de Freud, era um sintoma de sua necessidade masoquista de autopunição, que, em última análise, derivava de seu desejo de matar o pai. É bastante estranho que Freud nunca tenha dito uma palavra sobre essa autocura bastante notável" ${ }^{182}$. Assim, segundo o biógrafo, o escritor teria largado o jogo em função do aprofundamento do seu amor pela mulher e de algo decisivo que aconteceu durante a última incursão de Dostoiévski à Wiesbaden. Nessa cidade ele teve um sonho apavorante com o pai e, nas poucas vezes que ele havia sonhado com o pai, este previra terríveis desastres que aconteceram (Dostoiévski era muito supersticioso). Depois da noite do pesadelo, após perder tudo em um cassino, Dostoiévski se precipitou no alcance de um padre russo. No entanto, ao se aproximar da igreja que tomara como ortodoxa russa, ele percebeu que se tratava de uma sinagoga. Assim, segundo a hipótese lançada por Frank, "Podia ser que, na mente de Dostoiévski, esse erro indicasse, através de um sinal do alto, que seu vício o estava levando a uma proximidade degradante daquelas pessoas que estão ligadas, tradicionalmente, ao acúmulo de lucro desonesto [os judeus]. É possível que, no futuro, sempre que fosse tentado a jogar, essa lembrança degradante e desalentadora (para ele) continuasse a aparecer e agisse como um impedimento"183. Após esse ocorrido ele escreveu uma carta a mulher (como sempre havia feito até então), prometendo ter sido aquela a sua última aventura em uma mesa de jogo, fato que se concretizou. Segundo Frank, apesar da carta seguir os modelos das anteriores, dessa vez Dostoiévski estava falando a verdade.

Se, por um lado, Joseph Frank apresenta uma hipótese ousada e interessante acerca dos motivos que teriam levado Dostoiévski a largar o vício pelo jogo, por outro lado a explicação racional que ele apresenta para o vício é muito pouco crível, pois nove

\footnotetext{
${ }^{182}$ FRANK, Op. Cit., 2003, p. 556.

${ }^{183}$ Idem, p. 559, 560.
} 
entre dez jogadores inveterados afirmam que jogam com expectativas de lucros imediatos, e que o único problema, no entanto, é não saber ao certo a hora de parar. Utilizar os apertos financeiros de Dostoiévski como explicação também é pouco convincente, uma vez que não são todas as pessoas em dificuldades econômicas que se precipitam para as mesas de jogo. Assim, a impressão que fica ao leitor é que Frank tenta preservar Dostoiévski das conclusões psicanalíticas que tendem a incluí-lo entre os neuróticos patológicos, assim como da tradição biográfica que retratou o escritor russo como um jogador sem freios (não é por acaso que a crítica considera o pequeno romance $O$ Jogador de Dostoiévski uma obra com lampejos autobiográficos).

O tratamento que o biógrafo despende ao assunto do vício pelo jogo ilustra a maneira como Frank retrata o homem Dostoiévski, ou seja, como alguém que apesar dos momentos de instabilidade emocional nunca ultrapassou a linha tênue que separa a razão da loucura humana. Com o intuito de "normalizar" a personalidade do escritor russo, de apresentá-lo como um ser humano comum próximo de todos os outros e não como um gênio excêntrico, Frank evita carregar nas tintas quando o tema em pauta é o dos sofrimentos psíquicos que acompanharam Dostoiévski ao longo da sua vida.

A "humanização" do grande escritor com a qual a biografia de Joseph Frank brinda o leitor, ou seja, a maneira de retratar o homem Dostoiévski como um ser humano possível, com qualidades e defeitos como todos os outros é sem sombra de dúvida um dos méritos da obra. É interessante observar, porém, que essa aproximação não implica em uma "degradação" da imagem do escritor segundo a formulação de Freud $^{184}$. Uma vez que a tradição biográfica retratou Dostoiévski como uma personalidade complicada, a "normalização" do escritor desponta como uma alternativa

\footnotetext{
${ }^{184}$ Ver Capítulo 1 "O gênero biográfico” p. 29.
} 
para a figura de "gênio difícil", "defensor da Ortodoxia e do Czarismo" e "louco" forjada pelas incontáveis biografias escritas sobre a vida do romancista russo.

O outro lado da moeda é o fato da humanização do biografado ter sido acompanhada da ênfase de Frank na curva ascendente que o Dostoiévski artista experimentou durante a sua trajetória de vida. A crescente admiração que a obra de Dostoiévski despertou nos seus contemporâneos a partir da década de 1860, e principalmente o lugar de destaque nas letras e na vida pública russa que o escritor alcançou nos seus últimos anos - período reconstituído com afinco no quinto volume que Joseph Frank intitulou de Dostoiévski: O Manto do Profeta- são aspectos que o biógrafo destaca na sua narrativa.

É interessante prestar atenção na maneira como Joseph Frank termina a sua obra. No último capítulo, intitulado "Finale", Frank descreve os momentos finais de Dostoiévski e a repercussão que a morte do grande escritor gerou. Reproduzindo nas últimas linhas da biografia um discurso de Soloviov sobre Dostoiévski, o biógrafo assina embaixo das palavras do filósofo russo:

no ano passado, no festival Púchkin, Dostoiévski chamou Púchkin de profeta, mas o próprio Dostoiévski merece esse título com a maior razão(...) Assim como o mais alto poder do mundo vez por outra se concentra numa única pessoa, que representa um Estado, do mesmo modo o mais alto poder espiritual em cada época costuma pertencer em cada povo a um homem, que mais claramente do que todos apreende os ideais espirituais da humanidade, mais conscienciosamente do que todos se empenha em alcança-los, mais fortemente do que todos afeta os outros com suas pregações. Este líder espiritual do povo russo, nos tempos recentes, foi Dostoiévski"185

\footnotetext{
${ }^{185}$ FRANK, Op. Cit., 2007, p. 932.
} 
Assim, no final da biografia, ao transcrever o discurso que associa o escritor ao "líder espiritual do povo russo", portanto à figura do Profeta, Frank corrobora a análise da grandeza e importância de Dostoiévski na sociedade russa realizada por Soloviov. Se por um lado o biógrafo brinda o leitor com a representação humana de Dostoiévski, ele por outro lado garante que a grandiosidade da figura do romancista russo se sobreponha a esta esfera e arrebate a imagem do biografado. O resultado é a construção de uma leitura de Dostoiévski que sugere que, passado em retrospecto, os feitos do gigante das letras se sobrepõem às limitações do homem do cotidiano, do pensador político, social e religioso que também foi Dostoiévski. É digno de nota, por sua vez, que tal construção não é explicitada. Devido à pesquisa exaustiva realizada na documentação disponível sobre a vida de Dostoiévski, Frank opta por se colocar no plano do biógrafo neutro, que pouco aparece na narrativa biográfica. - "Some biographers choose Olympian detachment and leave the reader to discover where they stand"186. É o caso de Joseph Frank, que não expõe o movimento da sua biografia que eleva o homem Dostoiévski aos píncaros da sua grande obra.

A focalização de Dostoiévski através das lentes graduadas pela importância da arte do romancista é provavelmente um subproduto da intenção que Frank manifestou desde o prefácio do primeiro volume da sua biografia, de olhar para a vida do escritor russo com o intuito de lançar luz sobre a obra - obviamente que a esta intenção somouse o fascínio e a grande admiração do biógrafo pelo seu biografado. E, de qualquer maneira, apesar de aspectos questionáveis como a idealização do escritor já mencionada, o método de buscar compreender as obras por meio da investigação do contexto histórico de produção das mesmas é uma das mais importantes contribuições de Joseph Frank para os estudos dostoievskianos do nosso tempo. A acurada

\footnotetext{
${ }^{186}$ BACKSCHEIDER, Op. Cit., p. 118.
} 
reconstituição das questões com as quais a intelligentsia russa do século XIX se defrontou, e a inserção de Dostoiévski no contexto dessa história intelectual como um produto e ao mesmo tempo um agente do seu próprio tempo consiste em um dos principais acertos desta empreitada biográfica. Como será assinalado no próximo capítulo, essa atitude consistiu em um desafio aos caminhos interpretativos hegemônicos na academia norte-americana da qual Frank é parte.

Como já discutido anteriormente, o método de Frank se esteia na tese de que a grande particularidade da obra de Dostoiévski é a maneira como nela se conjugam as questões "malditas" - referentes especialmente à moral cristã - com os principais temas da época na qual o escritor viveu e produziu. No segundo volume da obra, o biógrafo nos brinda com a seguinte observação: “A força (e um pouco da fraqueza) da obra de Dostoiévski pode ser em último caso localizada na penetrante agudeza com que ele, antes de tudo, desejou comunicar o poder salvador desse núcleo escatológico da fé cristã $^{\prime 187}$. Parafraseando Joseph Frank, a força da biografia Dostoiévski (e um pouco da fraqueza) encontra-se na leitura que Frank empreendeu do grande escritor como um homem do seu tempo. Esta aproximação não destacou a grande revolução atemporal que Dostoiévski empreendeu ao criar o romance polifônico, a indefinição da personagem e a multiplicidade dos discursos livres de um denominador comum, que resultaram no apagamento deste homem da Rússia século XIX do corpo da sua grande obra literária.

\footnotetext{
${ }^{187}$ FRANK, Op. Cit., 2008,p. 104.
} 


\section{Capítulo 4. Frank, seus críticos e a eslavística norte-americana}

Ao longo desta pesquisa ressaltamos que Joseph Frank compôs uma obra monumental que figura entre as mais importantes biografias já escritas sobre Fiódor Dostoiévski. Também assinalamos que uma das razões para o sucesso da biografia foi a exaustiva pesquisa sobre a vida do escritor russo que envolveu o biógrafo por quase três décadas. É importante destacar, por fim, o contexto de produção da obra tanto para compreender o diálogo que o biógrafo travou com a eslavística norte-americana, quanto para delimitar o lugar ocupado pela mesma neste campo de estudos.

Como destacou Paul Murray Kendall no livro The Art of Biography, "under the aegis of science, the American biographer, then has received support and encouragement which are the envy of his fellows in the rest of the world"188. É o caso de Joseph Frank que, como mencionado no capítulo anterior, desenvolveu a sua pesquisa no âmbito das mais importantes instituições acadêmicas norte-americanas (Stanford, Princeton, etc) e francesas, com apoio financeiro das mesmas e de fundações como a Guggenheim Foundation, Rockfeller Foundation, entre outras. Além disso, Frank se inseriu em uma eslavística que, apesar da conjuntura de crise, - o encolhimento dos programas de Slavic Studies das principais universidades do país é um dos sintomas dessa crise - se mantém como uma das mais relevantes do mundo.

A história da eslavística norte-americana é muito curiosa e merece ser recuperada. $\mathrm{O}$ início dos estudos russos no país remonta aos anos anteriores a 1914, quando os EUA começam a se firmar na política internacional e almejam ampliar os seus horizontes intelectuais. É também a época quando grandes nomes da cultura russa (Tolstói,

\footnotetext{
${ }^{188}$ KENDALL, Op. Cit., p. 119.
} 
Tchékhov, Tchaikóvski etc.) passam a ser conhecidos no país. Assim, em 1914 havia três cadeiras de Russian Language and Literature nas Universidades norte-americanas, em Harvard, Columbia e Berkeley e dois cursos de Russian History: um em Berkeley e outro em Harvard.

A Revolução de 1917 inaugura um novo estágio da eslavística nos EUA, pois coloca a Rússia sob os holofotes e impulsiona a emigração de acadêmicos russos para as universidades norte-americanas. No decorrer da consolidação dessa área de estudos, a chegada de estudiosos dissidentes da União Soviética terá uma importância crucial, uma vez que "without their skills and intelligence, American Slavistics could hardly have turned into a full-fledged academic industry in such a short period of time" ${ }^{\text {"189 }}$.

A grande virada ocorre com as transformações impulsionadas pela II $^{\circ}$ Guerra Mundial. Alguns dias depois de Pearl Harbor, foi criado o ACLS Committee on Language Instruction in Emergency, que com o apoio de Fundações operou com o intuito de identificar as lacunas no conhecimento de outros idiomas e de aprimorar os materiais e métodos de ensino. O russo foi a primeira língua a ser ensinada em cursos intensivos (o ensino de mais de 40 línguas foi introduzido ou reforçado no âmbito deste programa), primeiro em Cornell, depois em muitas outras instituições. Logo ficou claro que o conhecimento de línguas estrangeiras deveria ser complementado com o estudo de culturas, e mais uma vez foi o russo, por meio da criação do Russian Area Program em Cornnell com o financiamento da Rockfeller Foundation que inaugurou os programas de estudos interdisciplinares sobre diversos países focados na língua, cultura, política e sociedade.

\footnotetext{
${ }^{189}$ STEINER, Peter. "Slavic Literary Studies Yesterday and Tomorrow". Modern Language Association, Profession (1987), p. 5.
} 
Durante os anos de conflito, muitos outros Area Studies Programs (desenvolvidos inclusive pelo Exército e pela Marinha), como o SSRC, foram criados e a língua russa e a União Soviética invariavelmente figuraram nesses programas. Independentemente do fato da União Soviética ter feito parte dos Aliados, os EUA não deixaram de incentivar as pesquisas em busca de informações estratégicas sobre o seu futuro antagonista geopolítico. Uma rede - "network" - de profissionais formada por acadêmicos, soldados, fundações oficiais e espiões se teceu determinada a construir "expertise" e a influenciar, além da vida intelectual acadêmica, a opinião pública e a política externa. Assim, o pontapé inicial para o vertiginoso crescimento do campo da eslavística nos EUA não foi dado durante a Guerra-Fria, apesar da conjuntura de rivalidade política datar desse momento histórico, mas sim durante a Segunda Guerra Mundial. Como escreveu David C. Engerman:

In the wake of the war, academic study of the USSR went from laughingstock to juggernaut, from a dispersed group of isolated scholars to a vibrant enterprise making headlines, advising presidents, and shaping foreign policy, all the while fulfilling the traditional academic roles of research and teaching. These changes took place quickly",190

As inovações em ensino e pesquisa desenvolvidas como esforços de Guerra foram aproveitadas nas universidades do país durante o pós-guerra e incorporadas nos programas de pós-graduação em estudos russos. A eslavística durante as décadas de 1950 e 1960 experimentou um crescimento vertiginoso, período que foi denominado

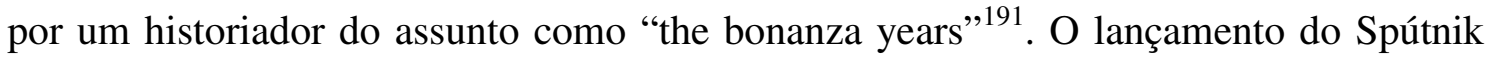
em 1957 foi um dos fatores que contribuiu determinantemente para que a eslavística

\footnotetext{
${ }^{190}$ ENGERMAN, David C. Know your Enemy - The rise and fall of America's Soviet Experts. New York: Oxford University Press, 2009, p. 3.

${ }^{191}$ Idem, p. 7.
} 
atingisse um grau de importância sui generis entre as áreas de estudos acadêmicos nos EUA.

Um ano depois do lançamento do satélite que fez decolar a corrida espacial, o governo norte-americano criou o National Defense Education Act (NDEA) para garantir a disseminação do ensino da língua russa e dessa forma preencher a lacuna linguística que passou a figurar entre as maiores ameaças aos interesses nacionais do país. Ao mesmo tempo, a rede de profissionais que se formou durante a II Guerra fortaleceu-se e expandiu-se. Nas palavras de Engerman, "this network took shape when the USSR was a difficult wartime ally, not an entrenched enemy, and dramatically changed the relationship between government and university. Their brief wartime fling became a long-term relationship during the Cold War" ${ }^{\prime 192}$. Assim, além da eslavística ter se transformado numa das maiores Area Studies e num dos principais programas de pósgraduação das Universidades dos EUA, ela obteve enorme relevância política e vultosos recursos financeiros por parte das grandes fundações, como a Rockefeller, a Carnegie e a Ford Foundation. Os especialistas em União Soviética - "Sovietologists" - se tornaram figuras politicamente influentes e, não apenas isso, figuras capazes de operar mudanças na política externa do Estado com base na sua "expertise".

Portanto, como sugerem os estudiosos do assunto, "in fact, Slavic studies in this country have grown not because of intellectual curiosity about the culture but because of the contingencies of a practical situation"193. E a situação prática era de natureza política e estratégica. Assim, a dúvida que paira sobre a história da eslavística norteamericana é até que ponto a relação deste campo de estudos com o governo caracterizou-se por um contundente apoio logístico e financeiro oficial, ou se este apoio

\footnotetext{
${ }^{192}$ Idem, p. 4.

193 STEINER, Op. Cit., 1987, p. 5.
} 
trouxe consigo o direcionamento das pesquisas realizadas no âmbito da academia para os assuntos de importância estratégica. Na bibliografia disponível despontam observações como a de que o interesse oficial não apenas acelerou a consolidação da eslavística, mas criou as condições para o surgimento deste campo de estudos. E, se por um lado os especialistas se fortaleceram graças às ações do governo, por outro lado eles não seguiram cegamente as direções oficiais, mas estipularam os seus focos e objetivos adaptando as iniciativas governamentais às suas necessidades.

Nesta parceria com ares de intervenção salta aos olhos o sucesso das humanidades. O seu destaque no âmbito do Russian Studies não foi fruto do acaso, mas o resultado das lições aprendidas com os programas de estudos desenvolvidos durante a Segunda Guerra que enfatizaram as competências linguísticas e o conhecimento das culturas dos outros países. Essas lições foram repetidas e aprofundadas durante a Guerra Fria, o que fez com que o conflito contra o gigante comunista fosse apelidado no país de "the social scientist's war" ${ }^{\prime 194}$.

Na década de 1960, a Ford Foundation e o State Department destinaram uma quantia de mais de 300 mil dólares por ano (cada um deles) para o financiamento do American-Soviet Scholarly Exchange Program, cientes de que 75\% dos participantes desse programa eram historiadores e humanistas. Outro indício dessa predominância das humanidades foi o fato do número de membros da American Association of Teachers of Slavic and East European Literature ter mais do que dobrado entre 1958 e 1962. Dessa forma:

While the government agencies and foundations that supported Russian Studies had created the field to learn more about the

\footnotetext{
${ }^{194}$ ENGERMAN, Op. Cit., p. 7.
} 
Politbure, they also created experts on Pushkin. Though they sought insights into Brezhnev, they also boosted the study of Bulgakov and, eventually, Bakhtin. ${ }^{195}$

Portanto, as condições propícias garantiram que grandes estudiosos se formassem e produzissem nas mais diversas áreas das humanidades com foco na cultura e nas letras eslavas nos Estados Unidos. Nos estudos literários, quadros da academia norte-americana alcançaram grande renome e projeção internacional como, por exemplo, os intelectuais E. Simmons, Gleb Struve, Roman Jakobson e René Wellek.

As duas grandes figuras dos estudos literários da eslavística norte-americana são os críticos René Wellek e Roman Jakobson, ambos intelectuais europeus emigrados. Jakobson, o mais célebre, chegou aos EUA no início da década de 1940 e ocupou uma cadeira de Czech Studies na University of Columbia, para em 1949 assumir a Cross Chair in Slavic Languages and Literature em Harvard. Membro do Círculo de Linguística de Praga antes de deixar a Europa, Jakobson trouxe para os EUA as preocupações do Formalismo Russo, que se opunham à leitura da obra de arte como um produto do seu próprio tempo e buscavam novos caminhos para compreensão da relação entre forma e conteúdo na expressão literária. As inovações linguísticas que Jakobson desenvolveu ultrapassaram os limites da eslavística e, apesar do intelectual ter atuado nessa área treinando "virtually all of the major Slavists in that [1950s] generation"196, ele não foi um eslavista do ponto de vista estrito, mas um linguista, cujas contribuições teóricas como o Estruturalismo não encontraram eco no interior dos estudos eslavos.

René Wellek é um caso parecido. Também ligado ao Círculo de Praga, o intelectual se afiliou em solo norte-americano à escola do New Criticism e ajudou a

\footnotetext{
195 Idem, p. 6.

196 ENGERMAN, David C. "The Ironies of the Iron Curtain: The Cold War and the Rise of Russian Studies in United States”. Cahiers du Monde russe, Vol. 45, No. 3/4 (Jul. - Dec., 2004), p. 486.
} 
promovê-la. Os New Critics construíram a sua hegemonia nos EUA em um período que se estendeu do final dos anos 1930 até a metade da década de 1960. Nos anos 30, o New Criticism se identificava como uma reação à modernização e aos seus subprodutos (a tendência homogeneizadora do mercado; a banalização da experiência como decorrência da industrialização e da vida nas cidades; a cultura de massas etc.) e a sua prática consistia na ênfase à integridade e na particularidade do texto literário e na preocupação com o significado (meaning). Uma vez que o significado da obra literária, na visão do New Criticism, não podia ser dissociado da forma de expressão deste significado, os estudos de literatura realizados no âmbito da escola teórica se voltaram para a técnica literária. De forma simplificada, a postura dos New Critics consistia na "decision not to concern themselves with the social and historical dimension of literary works"197, e de analisar o texto literário sem trazer nada externo a sua leitura.

O New Criticism permeou os estudos de eslavística via René Wellek. No entanto, o contrário não se verificou, ou seja, Wellek não foi bem sucedido em erguer a ponte entre as discussões particulares do campo dos estudos eslavos com a crítica literária preocupada com questões mais amplas (outros eslavistas eminentes também não conseguiram amplificar as discussões travadas na sua área de estudos). O isolamento dos eslavístas norte-americanos no contexto das humanidades é algo reiterado na bibliografia referente ao tema. Sem meias palavras, estudiosos afirmam que "as far as my institutional memory goes, Slavic literary scholars have always preferred to maintain a splendid isolation from their colleagues in other literatures" ${ }^{\prime 198}$, ou ainda, que "paradoxically, the Slavicists seem to be simultaneously behind and ahead of what their colleagues are doing, but almost never in sync with them"199. Exemplos do isolamento

\footnotetext{
${ }^{197}$ NUSSBAUM, Martha C. "The Narrative Imagination". IN: The Norton Anthology of Theory and Criticism, $2^{\text {nd }} E d, 2010$, p. 2323.

${ }^{198}$ STEINER, Op. Cit., 1987, p. 2.

${ }^{199}$ Idem, p. 6.
} 
dos eslavístas podem ser localizados na penetração da teoria Estruturalista na crítica literária norte-americana. No final dos anos 1960, o Estruturalismo se incorporou ao "mainstream" da crítica no país. Apesar da familiaridade dos eslavistas com o Estruturalismo (reforçada pela figura de Jakobson), este foi saudado como uma inovação intelectual francesa e se instalou nos EUA como uma moda parisiense. Outro exemplo é a aceitação de Bakhtin, cuja popularidade é muito menor entre eslavistas do que entre especialistas de outros departamentos, como o de Literatura Comparada. Ao isolamento somaram-se as divergências e dispersão no interior do campo de estudos, que cresceu vertiginosamente em um curto período de tempo.

Um sintoma dessa falta de sintonia é que a principal agenda da crítica norteamericana da metade do século XX consistia na definição do cânone literário moderno. $\mathrm{Na}$ busca pelos traços do modernismo, muitos críticos - afinados ou não com o movimento do New Criticism - se depararam com os grandes romances russos do século XIX ("Tolstoevsky") e os identificaram como obras canônicas. Estas, no entanto, foram lidas na chave do modernismo europeu e as suas especificidades russas foram praticamente ignoradas. Críticos como Lionel Trilling, Irving Howe e R. P Blackmur analisaram as obras dos romancistas russos independentemente da literatura produzida pelos eslavistas, algum deles inclusive (Trilling e Blackmur) se debruçaram sobre esses romances sem o domínio da língua russa.

Assim, diante deste panorama, a obra de Joseph Frank despontou como uma alternativa à "descontextualization of New Criticism and the move to emphasize the universal, rather than the centrally Russian, aspects of Dostoevsky's carrer"200 dos críticos norte-americanos que não adotaram a perspectiva dos New Critics, mas que estudaram os russos na chave da tradição literária europeia, portanto universalizante.

\footnotetext{
${ }^{200}$ ENGERMAN, Op. Cit, p. 149.
} 
Na entrevista que nos concedeu ${ }^{201}$, Joseph Frank afirmou que um dos principais motivos que o incentivaram a se debruçar sobre a obra de Dostoiévski foi a sua insatisfação com as interpretações que críticos como Blackmur (amigo pessoal de Frank), por exemplo, elaboraram sobre ela. Para ele, a limitação dessas interpretações devia-se principalmente ao fato desses críticos não dominarem a língua russa e, por conseguinte, terem lido as traduções e não os textos originais. Ambicionando interpretar as obras de forma a se aproximar o máximo possível das intenções originais do seu autor, Frank resolveu aprender a ler em russo e estudou a história da Rússia da época na qual Dostoiévski viveu.

Em resumo, Joseph Frank pertenceu à escola norte-americana do close reading, de leitura estrita dos aspectos formais do texto e compartilhou da desconfiança do estudo dos aspectos extraliterários da obra característica do seu ambiente acadêmico influenciado pelo New Criticism. Mas, mesmo assim, Frank inovou ao buscar compreender a produção literária de Dostoiévski a partir do período histórico no qual essas obras foram gestadas, além de ter dialogado com os eslavistas e os colocado em cena diminuindo assim a distância entre esses especialistas e os críticos "modernos" da geração da qual Frank faz parte. Como este "desvio de rota", esta solução original para o problema da compreensão da obra de Dostoiévski foi recebida na academia norteamericana?

As palavras com as quais Abbott Gleason, professor da Brown University, abre sua resenha publicada na revista Russian Review sobre Os Anos Milagrosos respondem à questão: “The enormous outpouring of critical enthusiasm for Joseph Frank's multivolume biography of Dostoevsky intimidates the reviewer. Everyone from the late Irving Howe to A. S. Byatt via Donald Fanger has proclaimed this to be one of the great

${ }^{201}$ Entrevista concedida à autora da dissertação em 10 de outubro de 2012. 
biographies of the twentieth century. For the reader who does not wish to disagree but who finds the critical atmosphere a bit humid, what is there to say about this $(\ldots)$ ?"202.

A biografia foi saudada nos Estados Unidos em uníssono como uma contribuição sem precedentes para a eslavística. Os analistas da obra de Joseph Frank tiveram suas altas expectativas confirmadas a cada novo volume publicado, e à recepção do quinto volume Sob o Manto do Profeta seguiu-se o consenso acerca da grande importância da biografia. E, como Gleason nos permite inferir, este consenso foi responsável por criar um ambiente desconfortável para as vozes dissonantes, em outras palavras para os estudiosos que porventura desejassem criticar de forma mais contundente algum aspecto da biografia.

A recepção extremamente favorável da obra de Joseph Frank pode ser mensurada através de conversas informais com acadêmicos norte-americanos (e britânicos portanto no ambiente acadêmico de língua inglesa) ${ }^{203}$, do levantamento dos catálogos de bibliotecas de universidades dos EUA, mais especificamente de bibliotecas de estudos $\operatorname{eslavos}^{204}$ e, por fim, da análise de revistas científicas. Nas páginas das principais publicações acadêmicas norte-americanas direcionadas aos estudos de eslavística ou de literatura em geral abundam resenhas sobre a biografia assinada por Joseph Frank ${ }^{205}$. Há

\footnotetext{
${ }^{202}$ GLEASON, Abbott. "Review: Untitled - Dostoevsky: The Miraculous Years, 1865-1871 by Joseph" . Russian Review, Vol. 55, No. 2 (Apr., 1996), p. 325.

${ }^{203}$ Importantes estudiosos da obra de Dostoiévski como, por exemplo, a professora da UC Berkeley Irina Paperno, ou a professora da Universidade de Cambridge Dianne Oenning Thompson (esta última escreveu uma resenha elogiosa ao volume The Miraculous Years para a Slavic Review) consideram magistral a biografia escrita por Joseph Frank e encontram poucos aspectos criticáveis na obra.

${ }^{204}$ Outro indício da centralidade da obra de Frank no contexto acadêmico norte-americano pode ser levantado a partir de uma simples visita à Slavic Library da UC Berkeley. A pequena biblioteca, cujo trunfo é exatamente concentrar apenas obras de referência nas suas estantes, exibe os cinco volumes da biografia de Frank ao lado das obras biográficas escritas por Konstantin Mochulsky e Leonid Grossman sobre a vida de Dostoiévski.

${ }^{205}$ Entre as publicações científicas cabem ser mencionadas: Russian Review, The Slavonic and East European Review, The Modern Language Review, Comparative Literature, The Slavic and East European Journal e Canadian Slavonic Papers.
} 
ainda publicações literárias de grande prestígio nas quais também constam textos críticos ou ensaios sobre Dostoiévski. ${ }^{206}$

Em algumas destas revistas e jornais acadêmicos os cinco volumes da biografia se encontram analisados, abrindo margem para a compreensão de como os críticos apresentam as suas expectativas nas resenhas dedicadas ao primeiro volume, que no caso são altamente positivas, e como estas expectativas são efetivamente atendidas conforme os volumes posteriores vão sendo lançados e, por fim, como as resenhas do último volume são praticamente uma celebração da conclusão da empreitada. ${ }^{207}$ Nestas revistas é possível se analisar de uma perspectiva histórica a recepção da biografia e compreender em que medida esta ganha importância entre os acadêmicos especialistas na obra de Dostoiévski, uma vez que ela se torna uma referência constante nos artigos publicados sobre o escritor russo e nas resenhas de outras biografias focadas na vida do grande romancista.

O levantamento do conteúdo dessas revistas a partir do volume no qual consta a primeira crítica sobre a biografia de Frank $^{208}$ oferece subsídios para a compreensão da recepção da obra. A atitude dos críticos de Frank se tornou cada vez mais positiva conforme os volumes da biografia foram sendo lançados, e a biografia se transformou em uma referência inescapável para todos os estudiosos que publicaram artigos sobre

\footnotetext{
206 É o caso da The Threepenny Review, que publicou um ensaio da premiada escritora inglesa A. S. Byatt sobre o quinto volume The Mantle of Prophet e da World Literary Today, na qual no seu espaço destinado a biografias consta uma resenha assinada pelo acadêmico Victor Terras sobre o primeiro volume de Dostoevsky de Frank. Outra revista literária importante é The Swanee Review, a mesma na qual no início da sua carreira Joseph Frank publicou o ensaio "Spatial Form in Modern Literature", que se tornou um clássico dos estudos da narrativa e elevou seu autor ao patamar dos grandes nomes da teoria literária na academia norte-americana.

${ }^{207}$ É o caso, por exemplo, das publicações Slavic Review, Russian Review e The Slavic and East European Journal.

${ }^{208}$ No caso da Slavic Review é o Volume 36, N. 2, Jun., 1977, no da Russian Review é o Volume 36, N.3, Jul, 1977 e no da The Slavic and East European Journal é o Volume 21, N.4, Winter, 1977 até os volumes mais recentes, que, no caso da Slavic Review é o Volume 71, N. 1, Spring, 2012, da Russian Review é Volume 71, N.3, Jul, 2012 e da The Slavic and East European Journal é o Volume 55, N. 2, Summer 2011.
} 
qualquer temática referente à Dostoiévski, principalmente a partir de 2002, ano da publicação do último volume - Sob o Manto do Profeta.

As resenhas sobre As Sementes da Revolta têm em comum o fato de elucidarem o método a partir do qual Joseph Frank orienta a sua empreitada biográfica. Dessa forma, na Russian Review Nicholas Rzhevsky, atualmente professor da Stony Brook University afirma: "On the one other occasion when Joseph Frank brought out his work in hardcover, Allen Tate remarked that he has the 'disquieting gift of going to the heart of whatever matter he undertakes to expound.' The gift is not an easy one to acquire in the contemporary critical environment since it often depends on an unpretentious concern for the particular cultural-historical reality of a literary text rather than the gaudier modem uses of it." ${ }^{209}$. Na Slavic Review, Ralph E. Matlaw, professor emérito (já falecido) da Universidade de Chicago, também explica o método de Frank e acrescenta o comentário: "To project Dostoevsky's work against the background of his life and time is a very difficult and grandiose undertaken" ${ }^{, 10}$. Por fim, no The Slavic and East European Journal, Nathan Rosen, da Universidade de Oregon, completa: "It is the first of four volumes covering in considerable detail Dostoevskij's life, times, and art - a synthesis that no one before has felt either competent or brave enough to attempt on such a large scale" ${ }^{211}$.

Portanto, os três críticos do primeiro volume apresentam o método que norteia a biografia deixando transparecer a estupefação com a ousadia do projeto e com as dificuldades que Frank enfrentaria para executá-lo. Todos também concordam que o resultado positivo que Frank obteve em seu primeiro volume é um indicativo de que a

\footnotetext{
${ }^{209}$ RZHEVSKY, Nicholas "Review: Untitled - Dostoevsky: The Seeds of Revolt, 1821-1849 by Joseph Frank" Russian Review, Vol. 36, No. 3 (Jul., 1977), p. 380-381.

${ }^{210}$ MATLAW, Ralph E. "Review: Untitled - Dostoevsky: The Seeds of Revolt, 1821-1849. by Joseph Frank" Slavic Review, Vol. 36, No. 2 (Jun., 1977), p. 347-348.

${ }^{211}$ ROSEN, Op. Cit., p. 539-541.
} 
biografia deverá ser completada de maneira satisfatória. Nathan Rosen expressou otimismo afirmando com relação aos futuros volumes que "if they maintain the high standard set in this first book, we shall have a landmark in Dostoevsky criticism"212. Matlaw também se mostra convencido de que Frank tem plenas condições de atingir de maneira satisfatória o seu objetivo quando afirma "it's a measure of Mr. Frank success that the first of his four planned volumes already establishes his study as the best general consideration of Dostoevsky's early life and work extent in any language and beyond that as a useful panorama of cultural and intellectual Russia in the 1840's"213. Rzhevsky, por fim, arremata: "all futures studies of Dostoevsky will have to begin here and with the volumes that will hopefully soon follow"214.

Entretanto, nos três artigos constam críticas ao primeiro volume da biografia, apesar do tom das críticas assegurar que os defeitos do livro não se sobrepõem às suas qualidades. Assim, Matlaw, por exemplo, chama atenção para o risco de se apontar a relevância de episódios de juventude de Dostoiévski para as suas obras de maturidade, além de identificar em alguns trechos da biografia uma especulação um tanto frouxa acerca da personalidade do escritor russo e de criticar a superficialidade da análise psicológica realizada por Frank. Nathan Rosen também critica a revisão que Frank realiza da teoria de Sigmund Freud desenvolvida no famoso ensaio "Dostoiévski e o Parricídio" e afirma que essa revisão, que se encontra no Apêndice 1 é "the weakest section of the book" ${ }^{215}$. Nicholas Rzhevsky, por fim, desconfia da imparcialidade que Frank afirma ter alcançado enquanto biógrafo, pois, nas suas palavras, "As the progeny

\footnotetext{
${ }^{212}$ Idem, p 541.

${ }^{213}$ MATLAW, Op. Cit., p. 348.

${ }^{214}$ RZHEVSKY, Op. Cit., p. 381.

${ }^{215}$ ROSEN, Op. Cit., p. 540.
} 
of Hegel and the contemporaries of Derrida and Kristeva we all know that such total objectivity and humility in the humanities is impossible"216.

As críticas não desaparecem por completo das resenhas publicadas nas três revistas sobre os volumes seguintes da biografia. Mas é perceptível que as mesmas se tornam menos incisivas e mais pontuais, como é possível se observar nas análises do quarto volume Os Anos Milagrosos. John Bartle, que assina a resenha para The Slavic and East European Journal ressalta que no volume em questão o método empregado por Frank se mostra extremamente eficaz, uma vez que ele consegue lançar uma nova luz crítica sobre as importantes obras de Dostoiévski da década de 1960 quando esclarece como experiências pessoais e reflexões sobre os problemas colocados pela época na qual o escritor russo viveu se transformaram em matéria prima para os romances Crime $e$ Castigo, O Idiota e Os Demônios, assim como para as obras de menor porte. E apenas no penúltimo parágrafo do texto ele aponta um defeito do livro: "Perhaps the least satisfactory part of Frank's book is the reading of The Idiot ${ }^{\text {"217 }}$, pois, na sua visão, paradoxalmente, o método não se mostrou muito frutífero na análise da obra mais pessoal de Dostoiévski. De qualquer maneira, no último parágrafo o crítico ressalta que "But this hardly detracts from the value of Frank's study",218.

A resenha publicada na Slavic Review é a da professora da Universidade de Cambridge, Dianne O. Thompson, que também enaltece os méritos da biografia e considera este volume a evidência de que o método eleito por Frank trouxe importantes contribuições para a eslavística focada em Dostoiévski. Já na Russian Review a resenha de autoria de Abott Gleason fornece um diagnóstico dos ânimos da recepção da obra de

\footnotetext{
${ }^{216}$ RZHEVSKY, Op. Cit., p. 381.

${ }^{217}$ BARTLE, John. "Review: untitled - Dostoevsky: The Miraculous Years, 1865-1871 by Joseph Frank". The Slavic and East European Journal, Vol. 41, No. 2 (Summer, 1997), p. 358.

${ }^{218}$ Idem, p. 358.
} 
Frank na academia norte-americana. A citação já mencionada neste capítulo, na qual ele expõe a difícil situação do resenhista que se depara com uma atmosfera crítica extremamente favorável ilumina os dois principais momentos da recepção da biografia: o primeiro momento é o da surpresa diante do método utilizado e da criação de altas expectativas em torno da empreitada, e o segundo momento é o da confirmação das expectativas e da promoção da biografia ao patamar das principais contribuições sobre a vida e a obra de Dostoiévski disponíveis não só na eslavística norte-americana, mas mundial, assim como a eleição da obra como uma das grandes biografias do século XX. O primeiro momento é o da publicação de As Sementes da Revolta e o segundo de Os Anos Milagrosos.

Quando o último volume Sob o Manto do Profeta é lançado, a reação da crítica é de comemoração e de reafirmação do que já havia sido constatado com a publicação do volume anterior. A crítica assinada por James P. Scanlan para a Slavic Review expressa o tom de celebração das resenhas sobre Sob o Manto do Profeta: "Even before it appeared, critics justly pronounced Frank's work a magnificent piece of literary scholarship; understandably, a chorus of superlatives has greeted the completion of the series. In such an exceptional case, a brief review can do little more than celebrate a singular achievement and suggest to benighted readers yet unfamiliar with the work why it is so good",219.

O lugar central que a biografia ocupa na eslavística norte-americana também se torna evidente nos artigos publicados nestas revistas sobre qualquer assunto relacionado a Dostoiévski. Na Russian Review, dezesseis artigos foram publicados de Junho de 1977 até Julho de 2012. Um breve levantamento dos títulos indica a variedade de temas

\footnotetext{
${ }^{219}$ SCANLAN, James. P. "Review: untitled - Dostoevsky: The Mantle of the Prophet, 1871-1881 by Joseph Frank”. Slavic Review, Vol. 64, No. 1 (Spring, 2005), p. 229.
} 
discutidos como, por exemplo, o artigo de James L. Rice "Dostoevsky's Medical History: Diagnosis and Dialectic" ${ }^{220}$, ou o artigo de Susanne Fusso "Dostoevsky's Comely Boy: Homoerotic Desire and Aesthetic Strategies in A Raw Youth"221. Independentemente do assunto, referências à biografia de Joseph Frank podem ser encontradas em $57 \%$ dos artigos publicados sobre Dostoiévski nessa revista. O número aumenta se forem consideradas outras obras de Frank, como, por exemplo, o Foreword que ele dirige à David I. Goldstein para a edição americana da obra "Dostoyevsky and the Jews", no qual desenvolve a ideia sobre o antissemitismo de Dostoiévski como um "guilty Anti-Semitism"222, argumento que reaparece no quinto volume da biografia Sob o Manto do Profeta. Neste caso, as referências às obras de Frank de maneira geral aparecem em $75 \%$ dos artigos da revista. Os números referentes a apenas a biografia ficam maiores também a partir de 2002, quando a obra é completada. Portanto, após a conclusão da biografia esta aparece citada em 67\% dos artigos. Algo semelhante se verifica nas revistas Slavic Review ${ }^{223}$ e The Slavic and East European Journal ${ }^{224}$.

Outro fato relevante é que Dostoiévski de Joseph Frank se torna um parâmetro de comparação para as outras obras biográficas escritas sobre Dostoiévski e resenhadas nas revistas. Na The Slavic and East European Journal, por exemplo, Robin Feuer Miller analisa a obra Dostoevsky de Richard Freeborn e aponta que "he gratefully

\footnotetext{
${ }^{220}$ RICE, James L. "Dostoevsky's Medical History: Diagnosis and Dialectic". Russian Review, Vol. 42, $\mathrm{N}^{\circ} 2$ (Apr, 1983) p. 131-161.

${ }^{221}$ FUSSO, Susanne. "Dostoevsky's Comely Boy: Homoerotic Desire and Aesthetic. Strategies in A Raw Youth”. Russian Review, Vol. 59, N4 (Oct, 200) p. 577-596.

${ }^{222}$ GOLDSTEIN, David I. Dostoevsky and the Jews. Texas: University of Texas Press, 1981, p. 31.

${ }^{223}$ Vinte e cinco artigos foram publicados sobre assuntos relacionados a Dostoiévski de Junho de 1977 até a primavera (Spring) de 2012. A biografia de Frank é citada em 52\% desses artigos, número que aumenta para $60 \%$ a partir do momento que consideramos outras obras de Frank além de Dostoevsky. Já a partir de 2002 a biografia de Frank aparece citada em 92\% dos artigos sobre o romancista russo.

${ }_{224}$ Nesta revista 53 artigos foram publicados sobre o romancista Dostoiévski. A biografia de Joseph Frank é mencionada em aproximadamente $40 \%$ desses artigos, e as obras de Frank em seu conjunto aparecem como referências para 56\% dos artigos publicados. De 2002 a 2011 (data do último volume analisado), doze artigos foram publicados sobre Dostoiévski e em apenas dois destes artigos não constam referencias à biografia de Joseph Frank. Assim, após 2002 a biografia aparece em 83\% dos artigos disponíveis sobre Dostoiévski.
} 
acknowledges his debt, throughout this entire little book, to his two primary sources: Joseph Frank's five volume biography of Dostoevsky and the Polnoe Sobranie Sochinenii v 30 Tomakh (1972-1990)"225. Outro exemplo pode ser localizado na Russian Review, na qual uma crítica sobre um estudo que investiga o círculo de Petrachévski e os revolucionários russos de 1848 indica o quanto a autoridade de Frank sobre a biografia de Dostoiévski é inquestionável, pois o crítico afirma: "Seddon [ J. H. Seddon, a autora do estudo] herself failed to take account of the most accessible scholarship in discussin Dostoevsky's relationship to the Petrashevtsy. She cites the first volume of Joseph Frank's biography, yet ignores the second, published in 1983, which devotes five chapters to the Petrashevtsy"226.

Portanto, o lugar de destaque que a obra de Frank ocupa na eslavística norteamericana é muito significativo. E a qualidade e importância da obra são as explicações principais para este sucesso, porém não as únicas, pois o contexto de produção da biografia, assim como uma característica de Frank como scholar também nos ajudam a entender melhor a boa vontade geral dos críticos norte-americanos com Dostoiévski.

O primeiro aspecto digno de nota é o período e o local onde a biografia foi produzida. Como já mencionado, os críticos do volume que abre a biografia têm em comum o fato de apresentarem o método que norteia a obra deixando transparecer a surpresa com a ousadia do projeto e com as dificuldades que Frank enfrentará para executá-lo. E, no contexto acadêmico norte-americano, as reservas com relação à biografia, ou mais especificamente com trabalhos que se dispõem a analisar a obra de escritores pelo liame da vida e do contexto histórico tem relação com a relevância da

\footnotetext{
${ }^{225}$ MILLER, Robin Feuer. "Review: Untitled - Dostoevsky by Richard Freeborn" The Slavic and East European Journal. Vol. 49, № 1 (Spring, 2005), p. 128-130.

226 PEGORELSKIN, Alexis E. "Review: Untitled - The Petrashevtsy: A Study of the Russian Revolutionaries of 1848 by J. H. Seddon”. Russian Review, Vol. 46, N³ (Jul, 1987), p. 330-331.
} 
escola teórica dos "novos" críticos - o New Criticism - e com a fobia quanto à incorporação de aspectos extra-literários para a análise do texto, como já ressaltado.

Por conseguinte, é possível afirmar que o sucesso de Dostoiévski é em parte explicável pelo fato de Joseph Frank ter se aventurado em um gênero desacreditado (o biográfico) e adotado um método pouco usual no ambiente acadêmico norte-americano (o de interpretar uma obra literária levando em consideração os aspectos exteriores a ela, como a biografia do autor e o contexto histórico de produção). Além disso, ele elaborou a biografia no período no qual o gênero biográfico experimentou o fim do ostracismo e foi encarado de forma mais simpática pelos intelectuais da academia: a partir da década de 80. Portanto, Frank escreveu durante os trinta anos nos quais os debates sobre os caminhos e descaminhos da biografia floresceram, e nos quais os biógrafos exploraram as novas possibilidades que esses debates sugeriram - a " bemvinda tentativa de estender os limites do gênero"227 à qual se referiu Frank no prefácio do seu segundo volume. Assim, surpreendendo os seus colegas de ofício, Frank conseguiu produzir uma obra de referência e oferecer uma contribuição significativa à literatura crítica sobre o escritor russo trilhando um caminho pouco usual no seu meio acadêmico.

Na década de 1980, o eminente eslavísta Victor Terras escreveu sobre a situação dos estudos sobre Dostoiévski na academia norte-americana: "perhaps we have reached the point where any truly fruitful contribution to Dostoevsky scholarship will have to be based on very close reading, accompanied by meticulous study of context and intertext, rather than on broader character and plot analyses"228. Joseph Frank valida essa afirmação quando compõe uma biografia focada no contexto histórico e social no qual a trajetória do romancista se desenrola, acompanhada de uma análise literária consistente,

\footnotetext{
${ }^{227}$ FRANK, Op. Cit., 2008,, p. 15, 16.

${ }^{228}$ TERRAS, Victor. "Review: Untitled - Dostoevsky and His New Testament, by Geir Kjetsaa; Tyrant and Victim in Dostoevsky by Gary Cox”. Slavic Review, Vol. 44, N³ (Autumn, 1985), p. 581-582.
} 
fornecendo assim uma contribuição de peso à literatura crítica existente sobre a obra de Fiódor Dostoiévski.

O segundo aspecto digno de nota, que também ajuda a explicar o fato da biografia Dostoiévski ter sido tão festejada pela crítica especializada, consiste no apreço dos acadêmicos norte-americanos pela personalidade de Joseph Frank. Frank foi um estudioso que, segundo os seus colegas de ofício, sempre ofereceu contribuições significativas para os estudos literários e a crítica literária, pois ao contrário do super especialista do presente, ele cultivou a postura do humanista do passado, interessado em entender, "the whole picture". Além disso, Frank foi reconhecidamente um acadêmico generoso, pois tinha apreço pelo simples ato de compartilhar o seu saber e aprender com os demais. Finalmente, foi um profissional muito acessível ${ }^{229}$.

As menções às qualidades do scholar Joseph Frank são muito fáceis de serem encontrados nas revistas científicas analisadas. Na resenha da obra Between Religion and Rationality, que Frank publica após a conclusão da biografia, o resenhista o descreve como: "profoundly knowledgeable, humanistic in his concerns, sympathetic to all sides, and, after all this decades of engagement, able to stand back and reflect about the large picture" 230 .

Joseph Frank tem a reputação de ter sido extremamente generoso como crítico e com os seus críticos, de nunca ter silenciado sobre os méritos de um trabalho mesmo quando este não seguia as suas orientações nem se encaixava nos seus pressupostos, ou fosse escrito por alguém que se colocava no campo oposto do ambiente acadêmico. $\mathrm{O}$ que não significa que Frank não tivesse o tino do bom crítico e se limitasse a elogiar a

\footnotetext{
${ }^{229}$ Surpreendeu-nos o fato de Frank ter concordado em nos conceder uma entrevista mesmo estando com problemas de saúde e mobilidade reduzida em outubro de 2012, poucos meses antes da sua morte, em fevereiro de 2013.

230 "Review: Untitled - Between Religion and Rationality: Essays in Russian Literature and Culture by Joseph Frank". The Slavic and East European Journal, Vol. 55, N 4 (Winter, 2011), p. 644-645.
} 
tudo e a todos, mas como afirma Abbot Gleason, "his sense of a good and important book is not limited by a narrow sense of "us" and "them," older or younger generation, right or left. Underlying Frank's generosity is a kind of humility: willingness, almost an eagerness, to acknowledge what others may have taught him",231.

Assim, é possível inferir que as características pessoais de Joseph Frank contribuíram para que a crítica se aproximasse com boa vontade das suas obras e que moderasse o seu tom com base no conhecido bom tom do biógrafo de Dostoiévski. Além disso, também é possível relacionar essas características positivas de Frank com o grande sucesso obtido por ele na incursão pelo gênero biográfico. Uma vez que, como já foi discutido anteriormente, o gênero biográfico demanda para além do rigor do trabalho intelectual uma considerável dose de sensibilidade e a faculdade de empatia, provavelmente devido à sua generosidade e consideração pelo outro Joseph Frank não encontrou grandes dificuldades em vestir a máscara do biógrafo e embarcar em uma jornada em busca da compreensão profunda do homem Dostoiévski.

A título de curiosidade, é interessante ressaltar o fato de que alguns críticos fizeram aproximações e comparações entre o biógrafo e o seu biografado. Na resenha sobre o último volume da obra, Scanlan afirma que a trajetória de um grande escritor em ascensão às portas da morte e da imortalidade é um tema invejável para qualquer biógrafo, e que Frank concluiu a sua empreitada biográfica "reaching the pinnacle of his own artistry in tandem with that of his subject" ${ }^{, 232}$. O crítico arrisca mais uma aproximação entre Frank e Dostoiévski: "Frank's effort lasted more than a quarter century (the first volume, Dostoevsky: The Seeds of Revolt, 1821-1849, was published

${ }^{231}$ GLEASON, Abbott. "Review: Untitled - Dostoevsky: The Miraculous Years, 1865-1871 by Joseph" Russian Review, Vol. 55, No. 2 (Apr., 1996), p. 325.

${ }^{232}$ SCANLAN, James. P. "Review: untitled - Dostoevsky: The Mantle of the Prophet, 1871-1881 by Joseph Frank". Slavic Review, Vol. 64, No. 1 (Spring, 2005), p. 229. 
in 1976)- roughly the duration of Dostoevskii's literary career, if we discount the nine years lost in Siberia.",233

Abott Gleason, na resenha dedicada ao terceiro volume da biografia Os Efeitos da Libertação, ressalta as diferenças entre a personalidade do biógrafo e a do biografado, que a esta altura da obra se tornam cada vez mais visíveis aos olhos do leitor. Nas suas palavras: "In the course of working through this huge study, the reader comes to know Frank and Dostoevsky extremely well."234 Ao leitor, entretanto, os dois "seem an interesting study in contrast. Dostoevsky's brilliance and wildness highlight Frank's more domestic virtues: his faithfulness, scrupulousness, caution, and great learning; his determination that every judgment be as well founded and judiciously phrased as he can make it; his by no means uncritical veneration for his subject.,"235

Assim, as duas personalidades tão distintas se fundem no corpo da obra Dostoiévski. E talvez o fato da personalidade de Dostoiévski ser oposta à de Frank que explique a razão da identificação mencionada nos capítulos anteriores entre biógrafo e biografado, já que a vida desmedida de Dostoiévski exerce uma irresistível atração sobre todos os admiradores do escritor e principalmente sobre aqueles que, como Frank, preferiram dedicar-se a uma existência de contemplação e estudos ao invés de ousarem ultrapassar todos os limites como fez Dostoiévski. Por fim, a convivência intensa de Frank com o escritor russo resultou no entusiasmo por Dostoiévski que ultrapassou as fronteiras da simples predileção por um autor e sua obra literária.

Portanto, é legitimo sugerir que a "veneração" de Frank pelo escritor, segundo as palavras de Gleason, foi um dos principais tropeços da biografia. Apesar da boa vontade

\footnotetext{
233 Idem, p. 229.

${ }^{234}$ GLEASON, Abott. "Review: Untitled -Dostoevsky: The Stir of Liberation, 1860-1865 by Joseph Frank. The Russian Review, Vol. 48, No. 1 (Jan., 1989), p. 96.

${ }^{235}$ Idem, p. 96.
} 
da crítica e das avaliações positivas se sobreporem às avaliações negativas, como foi frisado anteriormente, este aspecto da obra considerado problemático é perceptível em meio a tantos elogios. Alguns críticos notaram que em partes da sua biografia Frank "might have erred on the side of generosity"236, apresentando a vida de Dostoiévski em uma paleta de cores mais vivas do que os olhos do leitor conseguem captar. Como apontou Gary Rosenshield, "he often cannot conceal his sympathy for his subject as a person and thinker" 237 em algumas partes da biografia.

Em sua própria defesa, Joseph Frank afirmou em entrevista concedida em outubro de 2012 que a sua intenção foi contrapor-se à tradição biográfica que representou Dostoiévski como uma personalidade difícil e controversa. Nas suas próprias palavras: "It seem to me that (...) in Western European criticism (...) after everybody have praised him in the beginning there is a tendency (...) of criticizing him very harshly for his point of view [ideology]"238 Alguns críticos, porém, não concordaram que essa reação de Frank à antipatia da tradição crítica Ocidental especializada na vida de Dostoiévski tenha resultado em uma versão menos tendenciosa da personalidade do escritor russo.

Dessa forma, observações como a do crítico Donald Fanger indicam que também no ambiente acadêmico norte-americano certa parcela da crítica detectou que em partes da sua biografia Joseph Frank projetou na vida do escritor "not simply the logic but the ennobling qualities of the work"239. Essa projeção desvia a atenção do leitor da biografia para o fato também assinalado por Fanger que "precisely because Dostoevsky's thinking was emotional and mythological, what made great art might well be crude and

\footnotetext{
${ }^{236}$ GLEASON, Op. Cit., p. 326.

${ }^{237}$ ROSENSHIELD, Gary. "Review: untitled - Dostoevsky: The Mantle of the Prophet, 1871-1881 by Joseph Frank". Russian Review, Vol. 65, No. 2 (Apr., 2006), p. 305.

${ }^{238}$ FRANK, Joseph. Entrevista concedida à autora da dissertação em 10 de outubro de 2012.

239 FANGER, Donald."Review: Untitled- Dostoevsky The Years of Ordeal”. Russian Review, Vol. 44, No. 3 (Jul., 1985), p. 332.
} 
chauvinistic in the contexts of non-artistic expression."240. A intenção de iluminar a vida a partir do foco de luz fornecido pela obra pode ter gerado algumas distorções, como já assinalamos em momentos anteriores dessa investigação, no tratamento de aspectos como os posicionamentos políticos de Dostoiévski no final da sua vida, os seus comportamentos na convivência social e privada etc.

Na obra publicada recentemente, intitulada Between Religion and Rationality, Frank discorre sobre o tratamento despendido ao antissemitismo de Dostoiévski na biografia e nos seus trabalhos anteriores. Ele confessa que sempre considerou essa característica de Dostoiévski irrelevante para a compreensão da sua obra literária, mas reconhece que a questão necessariamente se interpõe entre o escritor e seus leitores e admiradores. Discutir esse tema foi para Frank, nas suas próprias palavras, “a painful task because Dostoevsky is a writer in whom I find so much else to admire"241.

Por conseguinte, o movimento que vai da obra para a vida que está na essência do método empregado em Dostoiévski carrega consigo um pouco das arestas dessa monumental biografia literária. Como já mencionado anteriormente, se, por um lado, o interesse pela obra do romancista russo repercutiu nesse tour de force que foi a composição da biografia, por outro lado esse olhar para a vida através das lentes da grande criação literária acabou resultando na idealização do homem Dostoiévski.

O escritor, que foi retratado em outras obras biográficas como um homem cuja natureza "needed this - extreme sensations, the struggle with fate, the foretaste of ruin" 242 emerge da biografia Dostoevsky como "a responsible person of great artistic and

\footnotetext{
${ }^{240}$ Idem, p. 332.

${ }^{241}$ FRANK, Joseph. Between Religion and Rationality. Essays in Russian Literature and Culture. New Jersey, Princeton: Princeton University Press: 2010, p. 172.

${ }^{242}$ MOCHULSKY, Op. Cit., p. 325.
} 
intellectual integrity" ${ }^{243}$, apesar das contradições da sua personalidade complexa serem apresentadas pelo biógrafo. É por esta razão que a idealização do escritor desemboca em um segundo aspecto questionável da obra de Frank: o tratamento que o biógrafo despende a "psicologia", ou a vida emocional do escritor russo. Já assinalamos que nas críticas ao primeiro volume A Sementes da Revolta Matlaw e Natan Rosen opinaram que a abordagem do tema da psicologia de Dostoiévski é o aspecto menos convincente da biografia. Na nossa apreciação sobre este assunto realizada em outro momento desta pesquisa sugerimos que ao fazer a crítica da análise de Sigmund Freud a respeito da personalidade "masoquista" de Dostoiévski, Frank normalizou em demasia certos comportamentos do romancista russo que pela sua própria natureza destoam abruptamente da "norma" como, por exemplo, o vício pelo jogo e o constante endividamento financeiro.

Sobre essa questão Donald Fanger também escreveu que "here and elsewhere one is reminded of the way narrative strategies convey a subliminal message in biography no less than in fiction. In this quasi-Tolstoyan telling of the Dostoevsky story, the latter's high art seems no longer to figure as the redemption of a life lived on a less balanced, less consistently admirable, more contradictory level. The revisionism may be appropriate, but one wishes to see it explicitly argued"244.

A síntese que emerge da análise das opiniões dos críticos norte-americanos sobre a biografia indica que aquelas menos favoráveis reforçam algumas das nossas hipóteses lançadas nesta pesquisa. O olhar benevolente para as fraquezas do biografado, a "normalização" da personalidade do escritor, a equiparação do homem Dostoiévski ao

\footnotetext{
${ }^{243}$ THOMPSON, Diane Oenning. "Review: Untitled - Dostoevsky: The Miraculous Years, 1865-1871. by Joseph Frank". Slavic Review, Vol. 54, No. 4 (Winter, 1995), p. 1055-1056.

${ }^{244}$ FANGER, Op. Cit., p. 332.
} 
artista Dostoiévski são aspectos comentados por alguns especialistas do contexto acadêmico de Joseph Frank. Portanto, a percepção de que o biógrafo fascinado pelo seu biografado vez ou outra emerge nas entrelinhas da narrativa da vida do romancista russo é compartilhada por uma amostra não desprezível de analistas da obra.

De qualquer maneira, apesar desses aspectos problemáticos, impera o consenso entre críticos especializados de que a biografia escrita por Joseph Frank é uma magistral incursão na vida, na obra e no tempo histórico de um escritor, o que faz dela uma das mais importantes biografias literárias do século XX e quiçá, de todos os tempos. Consenso assinado embaixo pela nossa leitura de Dostoiévski. 


\section{Conclusão}

Como já foi devidamente ressaltado, o gênero biográfico se encontra na encruzilhada entre as ciências humanas e a literatura, evidenciando os pontos de contato existentes entre ambas. Trata-se, portanto, de um gênero de difícil execução em função das contradições que nele se encerram que tanto o empurram para os domínios da verdade histórica, quanto o precipitam para o campo da ficção. Além disso, os debates contemporâneos que envolvem o gênero colaboraram para o desmoronamento dos antigos pressupostos que orientavam os autores de biografias. Dentre estes pressupostos destacam-se a concepção de que os homens são sujeitos coerentes, cujas trajetórias de vida lineares encerram um sentido; que é possível conhecer a "verdade" sobre alguém, assim como desvendar a personalidade de um homem à sua própria revelia etc. A partir de então, as dúvidas acerca da possibilidade da biografia não pararam de surgir, apesar de, paradoxalmente, o gênero consolidar-se entre os mais praticados e apreciados pelo público leitor.

A literatura é a grande responsável pela crise da biografia. Ela antecipa o problema que se torna central para o gênero biográfico a partir do século XIX (apesar de sua origem remontar ao século XVIII), que é a multiplicidade de uma personalidade e o caráter difuso de uma trajetória individual. É na literatura russa do século XIX que a complexidade do homem surge com toda a força, com destaque para as obras do escritor Fiódor Dostoiévski. Curiosamente, o mesmo Dostoiévski que inovou com a criação de personagens sem o acabamento redutor da definição do autor e, por conseguinte, nãobiografáveis, transformou-se em um dos escritores mais biografados de todos os tempos. 
Entre todas as obras biográficas, Dostoiévski de Joseph Frank foi saudada como uma das mais relevantes biografias já escritas sobre a vida do romancista russo. No contexto norte-americano, ela se tornou uma referência inescapável para qualquer estudioso interessado em Dostoiévski, e conseguiu o feito de ser saudada em uníssono como magistral por todos os críticos que publicaram resenhas em revistas e jornais acadêmicos sobre a obra. Não obstante, a biografia foi considerada nos EUA uma das melhores biografias literárias não apenas do século XX, mas de todos os tempos. Dessa forma, procuramos ressaltar que a biografia da autoria de Joseph Frank é um empreendimento muito bem sucedido, que atualiza o gênero biográfico, enriquece os estudos dostoievskianos, colabora com a historiografia da Rússia novecentista e, por conseguinte, faz jus ao grande entusiasmo dos seus leitores e críticos.

Na biografia Dostoiévski, Frank explora as possibilidades da biografia $e$ contexto e compõe uma obra que não rompe o equilíbrio esclarecedor entre uma trajetória humana e o contexto histórico e social no qual esta trajetória se desenrola. A opção pela biografia e contexto foi condicionada pela visão do biógrafo sobre a produção literária de Dostoiévski. Em sua opinião, as obras do escritor só se tornam inteligíveis na medida em que são lidas sob a luz do contexto histórico de produção das mesmas. Portanto, para Frank a particularidade do gênio de Dostoiévski reside no dom de abordar as grandes questões da humanidade nos termos dos acontecimentos urgentes do tempo em que ele viveu - a Rússia do século XIX. Dentre essas grandes questões Frank destaca o comprometimento de Dostoiévski com a moral do cristianismo. Assim, em oposição direta à Bakhtin, Frank defende que a unidade da obra de Dostoiévski depende da intromissão autoral, que é responsável por comunicar a visão do escritor russo sobre as grandes questões morais em torno das quais seus romances foram construídos. 
Do ponto de vista estritamente biográfico, é legítimo afirmar que apesar do comprometimento com a documentação e a postura de pesquisador objetivo e isento, Frank é um biógrafo extremamente "generoso" com o seu biografado. Um exemplo da "generosidade" é o tratamento sem o viés inquisitório de outros biógrafos sobre temas polêmicos como o antissemitismo, a xenofobia, o apoio ao Czarismo, assim como a relativização do vício pelo jogo e da infância sofrida (que segundo outros biógrafos teria resultado na "doença mental" de Dostoiévski), que resultou na atenuação da personalidade de "gênio difícil" forjada pelas incontáveis narrações da vida do escritor russo. Além disso, Frank não apaga a sua grande admiração e seu afeto por Dostoiévski, sentimentos que contribuem para que em alguns momentos da obra uma sutil identificação seguida pela projeção do biógrafo na vida narrada por ele torne-se perceptível. Por fim, é possível afirmar que o método escolhido por Frank, que o levou a aventurar-se na reconstituição da vida a partir do interesse pela obra, contribuiu para que os grandes feitos do escritor se interpusessem entre o biógrafo e a pessoa do biografado, resultando na equiparação do homem Dostoiévski ao grande artista Dostoiévski.

Portanto, a lição que fica da apreciação crítica da biografia Dostoiévski é que "the most invisible person in a biography is the most powerful - the author. At every moment his or her voice can be heard - but it isn't"245. Quando, no entanto, prestamos a atenção a essa voz, tendemos a duvidar da pertinência do gênero e a aceitar a tese da ilusão biográfica. O que obras como a de Joseph Frank nos mostram é que sempre é possível detectar a voz do biógrafo e driblar o direcionamento que essa voz sugere ao leitor. Como essa voz é inerente ao gênero, ela é um fator que acrescenta - e não dilui -

\footnotetext{
${ }^{245}$ BACKSCHEIDER, Op. Cit., p. 3.
} 
material de reflexão e potencial de construção de conhecimento ao gênero biográfico. A aventura de Joseph Frank evidencia que as biografias ainda são excelentes caminhos para a compreensão das obras e dos homens que estão por trás dessas obras. E, como efeito colateral, dos homens que estão por trás das obras interessadas em desvendar a personalidade de outros homens. 


\section{BIBLIOGRAFIA}

\section{Sobre o Gênero Biográfico:}

AVELAR, Alexandre de Sá. “A biografia como escrita da História: possibilidade, limites e tensões”. Dimensões, vol. 24, 2010, p. 157-172

BACKSCHEIDER, Paula R. Reflections on Biography. New York: Oxford University Press, 1999

BORGES, Vavy Pacheco. “ O ‘eu’ e o ‘outro’ na relação biográfica: algumas reflexões. In: NAXARA, Márcia; MARSON, Izabel; BREPOHL, Marion (Org.). Figurações do outro. Uberlândia: EDUFU, 2009, p. 225-238.

BOURDIEU, Pierre "A ilusão biográfica" in. FERREIRA, Marieta de Moraes e AMADO, Janaina (orgs) Usos e Abusos da História Oral. Rio de Janeiro: Editora FGV, $2000,3^{\circ} \mathrm{Ed}$.

CLIFFORD, James L. Ed. Biography as an Art: Selected Criticism 1560-1960. New York: Oxford UP, 1962.

DOSSE, François, O Desafio Biográfico - Escrever uma Vida. São Paulo: Edusp, 2009.

EDEL, Leon. Writing Lives. Principia Biographica. New York/ London: W. W. Norton and Company, 1984.

GUSDORF, Georges, Les Écritures du Moi: Lignes de vie 1. Paris: Odile Jacob, 1991. Auto-Bio-Graphie: Lignes de Vie 2. Paris: Odile Jacob, 1991. 
HAMILTON, Nigel. Biography: A Brief History. Harvard University Press: Cambridge, Massachusetts/ London, England, 2007.

LEE, Hermione. Body Parts. Essays in Life Writing. London: Chatto \& Windus, 2005.

LEITE, Dante Moreira, O Amor Romântico e Outros Temas. São Paulo: Edusp, 1979.

LEJEUNE, Philippe, Le Pacte Autobiographique. Paris: Seiul, 1975.

Je Est un Autre: L’Autobiographie de la Littérature aux Médias.

Paris: Seuil, 1980.

LEVI, Giovanni "Usos da biografia” in. FERREIRA, Marieta de Moraes e AMADO, Janaina (orgs) Usos e Abusos da História Oral. Rio de Janeiro: Editora FGV, 2000, 3. ed.

LOWENTHAL, David, The Past is a Foreign Country. Cambridge: Cambridge University Press, 1990.

MAUROIS, André, Aspects de la Biographie. Paris: Au Sans Pareil, 1928.

NADEL, Ira Bruce. Biography. Fiction, Fact and Form. The MacMillan Press LTD, 1984.

OATS, Stepen B. ed. Biography as a High Adventure: Life-Writers Speak on Their Art. Amherst: University of Massachusetts Press, 1986.

O'CONNOR, Ulick. Biographers and the Art of Biography. Dublin: Wolfhound Press, 1991.

PARKE, Catherine N. Biography. Writing Lives. New York: Twayne Publishers, 1996.

RICOEUR, Paul. Temps et récit. Paris: Seuil, 1984. 
Soi-même comme un autre. Paris: Seuil, 1996.

ROLLYSON, Carl. A Higher Form of Cannibalism? Adventures in the art and politics of biography. Chicago: Ivan R. Dee, 2005

SCHMIDT, Benito Bisso. "Construindo Biografias- Historiadores e Jornalistas: Aproximações e Afastamentos” Revista Estudos Históricos, Vol. 10, №19, 1997, disponível em http://virtualbib.fgv.br/ojs/index.php/reh/article/viewFile/2040/1179. "Grafia da vida: reflexões sobre a narrativa biográfica". História Unisinos, v 8, n.10, p 131-142, jul;dez. 2004.

SIMMEL, Georg. On the individuality and social forms. Chicago: The University of Chicago Press, 1971.

TAYLOR, Charles. As fontes do Self: a construção da identidade moderna. São Paulo: Loyola, 1997.

TEZZA, Cristovão. "Literatura e Biografia” Conferência apresentada no XI Congresso Internacional da ABRALIC - Tessituras, Interações e Convergências. São Paulo, USP, 16 de julho de 2008 .

\section{Biografias:}

BARTHES, Roland, Sade, Fourier, Loyola. Paris: Éditions du Seuil, 1971.

BONA, Dominique. Stefan Zweig, Rio de Janeiro: Record, 1999.

CARR, Edward Hallett. Dostoevsky 1821-1881. London: Unwin Books, 1962.

DINES, Alberto. Morte no Paraíso. Rio de Janeiro: Rocco, 2004, 3. ed. amp. 
FRANK, Joseph, Dostoiévski: As Sementes da Revolta 1821- 1849. São Paulo: Edusp, 2008. 2. ed. rev.

Dostoiévski: Os Anos de Provação 1850-1859. São Paulo: Edusp, 2008.

2. ed. rev.

Dostoiévski: Os Efeitos da Libertação 1860-1865. São Paulo: Edusp,

2002.

, Dostoiévski: Os Anos Milagrosos 1865-1871. São Paulo: Edusp, 2003.

, Dostoiévski: O Manto do Profeta 1871-1881. São Paulo: Edusp, 2007.

, Dostoevsky: A Writer in His Time. Princeton, New Jersey: Princeton

University Press, 2010.

GROSSMAN, Leonid. Dostoevsky - A biography. The Bobbs-Merrill Company, INC.

Indianapolis/ New York, 1975.

LEVINSON, André, A Vida patética de Dostoievski. Rio de Janeiro: Casa Editora Vecchi Ltda, 1942.

MOCHULSKY, Konstantin. Dostoevsky, His Life and Work. Translated, with an introduction, by Michael A. Minihan. Princeton University Press, 1967.

PERSKY, Serge, - La Vie et L'ceuvre de Dostoievsky. Paris: Payot , 1924.

ROSA, Virginio Santa, Dostoievski, um cristão torturado. Rio de Janeiro: Editora Civilização Brasileira, 1980.

TROYAT, Henry, Dostö̈evsky. Rio de Janeiro: Americ=Edit, 1940.

ZWEIG, Stefan. Dostoïevsky. Paris: Les Éditions Rieder, 1929. 


\section{Obras de Dostoiévski,}

DOSTOIÉVSKI, Fiódor. O Idiota. Tradução de Paulo Bezerra. São Paulo: Editora 34, 2002.

\section{Crime e Castigo. Tradução de Paulo Bezerra. São Paulo: Editora}

$34,2000$.

. Os Demônios. Tradução de Paulo Bezerra. São Paulo: Editora

34, 2004.

. Memórias do Subsolo. Tradução de Boris Schnaiderman. São

Paulo: Editora 34, 2000.

- Gente Pobre. Tradução de Fátima Bianchi. São Paulo: Editora

34, 2009.

Niétotchka Niezvânova. Tradução de Boris Schnaiderman. São

Paulo: Editora 34, 2002.

O Jogador. Tradução de Boris Schnaiderman. São Paulo:

Editora 34, 2004.

Os Irmãos Karamázov. Tradução de Paulo Bezerra. São Paulo:

Editora 34, 2008.

. O Eterno Marido. Tradução de Boris Schnaiderman. São Paulo:

Editora 34, 2003.

DOSTOEVSKY, Fyodor. The Adolescent. A new translation by Andrew MacAndrew.

New York/London: W. W. Norton \& Company, 1971. 


\section{Sobre Dostoiévski e Joseph Frank:}

BAKHTIN, Mikhail, Problemas da Poética de Dostoiévski, tradução direta do russo, notas e posfácio de Paulo Bezerra - Rio de Janeiro: Forense Universitária, 2010, 5. Ed.

BERNARDINI, Aurora Fornoni “O Senhor Dostoiévski”. Folha de São Paulo Mais!, São Paulo, 13 jan. 2008. p. 6-7.

"Dura Provação: Dostoiévski - Os Anos de Provação, Joseph Frank", D. O. Leitura, São Paulo, n 10, Outubro de 2000, p 8-9.

CARA, Salete de Almeida "O desafio Dostoiévski”". Jornal de Resenhas: de abril de 2001 a novembro de 2002. São Paulo: Discurso Editorial, 2002.

FRANK, Joseph. Pelo Prisma Russo. Ensaios Sobre Literatura e Cultura. São Paulo: Editora da Universidade de São Paulo, 1992.

Between Religion and Rationality. Essays in Russian Literature and Culture. New Jersey: Princeton University Press, 2010.

FREUD Sigmund, "Dostoievski e o Parricídio" In: Obras Psicológicas Completas. Rio de Janeiro: Imago Editora, Vol. XXI.

JACKSON, Robert Louis (Ed.) Dostoevsky New Perspectives. New Jersey: PrenticeHall, Inc., Englewood Cliffs, 1984.

POGGIOLI, Renato. The Phoenix and The Spider. Harvard University Press, Cambridge, 1957.

SCHNAIDERMAN, Boris. "O Manto e o Profeta". O Estado de S. Paulo, Domingo, 23 de março de 2008 p. D9. 


\section{Sobre Eslavística Norte Americana e o New Criticism:}

American Contributions to the International Congress of Slavists, 1978, 1983, 1988, 1993, 1998, 2003.

EMERSON, Caryl. "Slavic Studies in a Post- Communist, Post 9/11 World: For and Against Our Remaining in the Hardcore Humanities". The Slavic and East European Journal, Vol. 46, №3 (Autumn, 2002), pp. 449-464.

ENGERMAN, David C. Know Your Enemy - The Rise and Fall of America's Soviet Experts. David C. Engerman. New York: Oxford University Press, 2009.

"The Ironies of the Iron Curtain: The Cold War and the Rise of Russian Studies in United States" Cahiers du Monde russe, Vol. 45, No. 3/4 (Jul. - Dec., 2004), p 465-496.

FISHER, Harold H. (Ed.) American Research on Russia. Indiana University Press, 1959.

GALLAGHER, Catherine. "The History of Literary Criticism" Daedalus Vol. 126, No.

1, American Academic Culture in Transformation: Fifty Years, Four Disciplines

(Winter, 1997), pp. 133-153.

MANNING, Clarence Augustus. A History of Slavic Studies in the United States. Princeton University Press, 1957.

NUSSBAUM, Martha C. “The Narrative Imagination”.The Norton Anthology of Theory and Criticism, $2^{\text {nd }} \mathrm{Ed}, 2010$

STAINER, Peter. "Slavic Literary Studies Yesterday and Tomorrow". Modern Language Association, Profession, (1987), PP 2-9. 
Artigos e resenhas críticas sobre Dostoiévski e sobre Dostoevsky de Joseph Frank, publicados em revistas científicas e literárias internacionais:

BARTLE, John. "Review: untitled - Dostoevsky: The Miraculous Years, 1865-1871 by Joseph Frank". The Slavic and East European Journal, Vol. 41, No. 2 (Summer, 1997), pp. 357-358.

BELKNAP Robert, L. "Review: Untitled - Dostoevsky: The Stir of Liberation, 18601865 by Joseph Frank". The Slavic and East European Journal, Vol. 32, No. 2 (Summer, 1988), pp. 317-318.

BYATT A. S. "Review: Untitled - Dostoevsky: The Mantle of the Prophet, 1871-1881 by Joseph Frank; Suicide as a CulturalInstitution in Dostoevsky's Russia by Irina Paperno".The Threepenny Review, No. 93 (Spring, 2003), pp. 5-8.

COX, Gary. "Review: Untitled - Dostoevsky: The Stir of Liberation 1860-1865. by Joseph Frank” Slavic Review, Vol. 47, No. 2 (Summer, 1988), pp. 368-369.

FANGER, Donald.“Review: Untitled- Dostoevsky The Years of Ordeal”. Russian Review, Vol. 44, No. 3 (Jul., 1985), pp. 331-333.

FUSSO, Susanne. “Dostoevsky’s Comely Boy: Homoerotic Desire and Aesthetic. Strategies in A Raw Youth”. Russian Review, Vol. 59, N4 (Oct, 200) pp 577-596. "Review: Untitled - Between Religion and Rationality: Essays in Russian Literature GLEASON, Abbott. "Review: Untitled - Dostoevsky: The Miraculous Years, 18651871 by Joseph"The Russian Review, Vol. 55, No. 2 (Apr., 1996), pp. 325-326. . "Review: Untitled -Dostoevsky: The Stir of Liberation, 1860-1865 by Joseph Frank. The Russian Review, Vol. 48, No. 1 (Jan., 1989), pp. 96-97. 
GORRA, Michel. "Review: Cliffhanger”. The Hudson Review, Vol 38, n¹ (Spring 1985), p146-148.

JONES, Malcon. V. "Review: Untitled - Dostoevsky: The Seeds of Revolt, 1821-1849 by Joseph Frank" The Slavonic and East European Review, Vol. 56, No. 1 (Jan., 1978), pp. 121-122.

LOCK, Charles." Review: Untitled - Dostoevsky: The Miraculous Years, 1865-1871 by Joseph Frank; A Writer's Diary. VolumeOne: 1872-1876. Volume Two: 1877-1881 by Fyodor Dostoevsky”. Canadian Slavonic Papers / Revue Canadienne des Slavistes, Vol. 38, No. 3/4 (SEPTEMBER-DECEMBER 1996), pp. 505-508.

MATLAW, RALPH. E. "Review: Untitled - Dostoevsky: The Years of Ordeal, 18501859 by Joseph Frank" The Slavic and East European Journal, Vol. 29, No. 1 (Spring, 1985), pp. 103-104.

"Review: Untitled - Dostoevsky: The Seeds of Revolt, 1821-1849. by

Joseph Frank" Slavic Review, Vol. 36, No. 2 (Jun., 1977), pp. 347-348.

MCMILLIN Arnold. "Review: (Untitled) - Dostoevsky: The Miraculous Years 18651871”, The Slavonic and East European Review, Vol. 74, №3 (Jul 1996) pp 500-512. . "Review: Untitled - Dostoevsky: The Mantle of the Prophet, 1871-1881". The Slavonic and East European Review, Vol. 81, No. 2 (Apr., 2003), pp. 320-321.

MILLER, Robin Feuer. "Review: Frank's Dostoevsky - Dostoevsky: The Mantle of the Prophet, 1871-1881 by Joseph Frank" The Slavic and East European Journal, Vol. 47, No. 3 (Autumn, 2003), pp. 471-477.

"Review: Untitled - Dostoevsky by Richard Freeborn" The Slavic and East European Journal. Vol. 49, N 1 (Spring, 2005) pp 128-130. 
OFFORD, Derek. "Review: Untitled - Dostoevsky: The Mantle of the Prophet, 18711881 by Joseph Frank". The Modern Language Review, Vol. 100, No. 4 (Oct., 2005), pp. 1164-1165.

PEGORELSKIN, Alexis E. "Review: Untitled - The Petrashevtsy: A Study of the Russian Revolutionaries of 1848 by J. H. Seddon”. Russian Review, Vol. 46, N³ (Jul, 1987) pp 330-331.

PEVEAR, Richard - "Review: To find The Man in Dostoevsky", The Hudson Review, Vol 55, N³ (Autumn, 2002) pp 495-503.

REEVE, F. D. 'Review: Dostoevsky's Life: The Final Chapters - Dostoevsky: The Mantle of the Prophet, 1871-1881 by Joseph Frank" The Sewanee Review, Vol. 112, No. 2 (Spring, 2004), pp. 304-307. . "Review: Masks of Dostoevsky - Dostoevsky: The Miraculous Years, 1865-1871 by Joseph Frank”.The Sewanee Review, Vol. 103, No. 3 (Summer, 1995), pp. $459-463$.

RICE, James L. “Dostoevsky’s Medical History: Diagnosis and Dialectic”. Russian Review, Vol. 42, № 2 (Apr, 1983) pp 131-161.

ROSEN, Nathan "Review: Untitled - Dostoevsky: The Seeds of Revolt, 1821-1849 by Joseph Frank". The Slavic and East European Journal, Vol. 21, No. 4 (Winter, 1977), pp. 539-541.

ROSENSHIELD, Gary. "Review: untitled - Dostoevsky: The Mantle of the Prophet, 1871-1881 by Joseph Frank" Russian Review, Vol. 65, No. 2 (Apr., 2006), pp. 304-305. 
RZHEVSKY, Nicholas “Review: Untitled - Dostoevsky: The Seeds of Revolt, 18211849 by Joseph Frank" Russian Review, Vol. 36, No. 3 (Jul., 1977), pp. 380-38.

SCANLAN, James. P. "Review: untitled - Dostoevsky: The Mantle of the Prophet, 1871-1881 by Joseph Frank". Slavic Review, Vol. 64, No. 1 (Spring, 2005), pp. 229230.

TERRAS, Victor. "Review: Untitled - Dostoevsky: The Seeds of Revolt 1821-1849 by Joseph Frank” World Literature Today, Vol. 51, No. 2 (Spring, 1977), p. 296. " "Review: Untitled -Dostoevsky: The Seeds of Revolt 1821-1849 by Joseph Frank" World Literature Today, Vol. 51, No. 2 (Spring, 1977), p. 296. ."Review: Untitled - Dostoevsky and His New Testament, by Geir Kjetsaa; Tyrant and Victim in Dostoevsky by Gary Cox”. Slavic Review, Vol. 44, N³ (Autumn, 1985) pp 581-582.

THOMPSON, Diane Oenning. "Review: Untitled - Dostoevsky: The Miraculous Years, 1865-1871. by Joseph Frank". Slavic Review, Vol. 54, No. 4 (Winter, 1995), pp. 10551056.

WASIOLEK, Edward. "Review: Untitled -Dostoevsky The Seeds of Revolt 1821-1849 by Joseph Frank". Comparative Literature, Vol. 30, No. 1 (Winter, 1978), pp. 92-94. - "Review: Untitled - Dostoevsky The Miraculous Years 18651871 by Joseph Frank", Comparative Literature, Vol 48, N4 (Autumn, 1996) pp 387389.

WOODCOCK, George - "Dostoevsky: Sources and Visions", The Sewanee Review, Vol 93, N² (Spring, 1985) pp 293-300. 


\section{Gerais:}

AUERBACH, Erich. Mimesis: a representação da realidade na literatura Ocidental. São Paulo: Perspetiva, 1971.

BARBOSA, João Alexandre. Mistérios do Dicionário e outras crônicas literárias, São Paulo: Ateliê Editorial, 2004.

CANTIMORI, Delio. Storici e Storia. Metodo, caratteristiche e significato del lavoro storiografico. Einaudi Paperbacks, Torino, 1971, seconda edizione.

HOBSBAWN, Eric. Tempos interessantes- Uma vida no século XX. São Paulo: Companhia das Letras, 2002.

Le GOFF, Jacques. História e Memória. Campinas: UNICAMP, 2010, 5 Ed.

LUKÁCS, Georg. A Teoria do Romance. São Paulo: Editora 34, 2000.

SAFATLE, Vladimir, “O Fantasma de Sigmund”. Folha de S. Paulo, Domingo, 12 de junho de 2011, PP. 4 e 5.

SEVCENKO, Nicolau. A Corrida Para o Século XXI: no loop da montanha-russa. São Paulo: Companhia das Letras, 2001.

WELLEK, René. Discriminations: Further Concepts of Criticism. New Haven and London, Yale University Press, 1970.

WHITE, Hayden. Meta-História: a imaginação histórica do século XIX. São Paulo: Editora da Universidade de São Paulo, 2008, $2^{\circ}$ Ed. “Teoria literária e escrita da história". Estudos Históricos, v. 7, n 13, p. 21-48, 1994. 
WOOLF, Virginia. Orlando. Rio de Janeiro: Nova Fronteira, 1978.

The Norton Antology of Theory and Criticism, $2^{\circ} \mathrm{ed}, 2010$. 